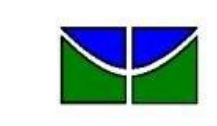

UnB

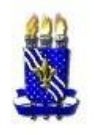

UFPB

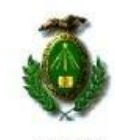

UFRN

\author{
UNIVERSIDADE DE BRASÍLIA - UnB \\ UNIVERSIDADE FEDERAL DA PARAÍBA - UFPB \\ UNIVERSIDADE FEDERAL DO RIO GRANDE DO NORTE - UFRN
}

Programa Multi-institucional e Inter-Regional de Pós-Graduação em Ciências Contábeis

CAMILA CATARINE DE ARAUJO AZEVEDO

EVOLUÇÃO DA CAPACIDADE PREDITIVA DA INFORMAÇÃO CONTÁBIL:

Um estudo a partir dos disclosures das Companhias listadas na BM\&FBovespa após a adoção das Normas Internacionais de Contabilidade no Brasil

NATAL - RN 
EVOLUÇÃo DA CAPACIDADE PREDITIVA DA INFORMAÇÃo CONTÁBIL: um estudo a partir dos disclosures das Companhias listadas na BM\&FBovespa após a adoção das Normas Internacionais de Contabilidade no Brasil

Dissertação apresentada ao Programa Multi-institucional e Inter-Regional de Pós-Graduação em Ciências Contábeis da Universidade de Brasília, Universidade Federal da Paraíba e Universidade Federal do Rio Grande do Norte, em cumprimento às exigências para obtenção do grau de Mestre em Ciências Contábeis.

Orientador: Prof. Dr. Adilson de Lima Tavares 


\title{
EVOLUÇÃO DA CAPACIDADE PREDITIVA DA INFORMAÇÃO CONTÁBIL: um estudo a partir dos disclosures das Companhias listadas na BM\&FBovespa após a adoção das Normas Internacionais de Contabilidade no Brasil
}

\begin{abstract}
Dissertação submetida à apreciação do Curso de Mestrado do Programa Multiinstitucional e Inter-Regional de PósGraduação em Ciências Contábeis (UnB/UFPB/UFRN), como requisito para obtenção do título de Mestre em Ciências Contábeis.
\end{abstract}

Comissão Avaliadora:

\footnotetext{
Prof. Dr. Adilson de Lima Tavares

UnB/UFPB/UFRN

(Orientador)
}

Prof. Dr. Diogo Henrique Silva de Lima Universidade Federal do Rio Grande do Norte

(Membro interno)

Prof. Dra. Thaiseany de Freitas Rêgo Universidade Federal Rural do Semi-Árido

(Membro externo) 
Azevedo, Camila Catarine de Araujo.

Evolução da capacidade preditiva da informação contábil: um estudo a partir dos disclosures das Companhias listadas na BM\&FBovespa após a adoção das Normas Internacionais de Contabilidade no Brasil / Camila Catarine de Araujo Azevedo. - Natal, RN, 2016.

$103 \mathrm{f}$.

Orientador: Prof. Dr. Adilson de Lima Tavares.

Dissertação (Mestrado em Ciências Contábeis) - Universidade Federal do Rio Grande do Norte. Centro de Ciências Sociais Aplicadas. Programa Multi-institucional e inter-regional de Pós-graduação em Ciências Contábeis.

1. Contabilidade - Dissertação. 2. Informação contábil - Dissertação. 3. Capacidade Preditiva Dissertação. 4. Análise discriminante - Dissertação. 5. Índices econômico-financeiros - Dissertação. I. Tavares, Adilson de Lima. II. Universidade Federal do Rio Grande do Norte. III. Título. 


\section{AGRADECIMENTOS}

A Deus, por sempre me acompanhar em tudo que faço em minha vida, abençoando-me e encorajando-me para concretizar mais este sonho; bem como a proteção de Nossa Senhora de Sant'Ana, que me ajudou nesta caminhada árdua e, muitas vezes, estressante, mas, sem dúvida, gratificante.

A minha família, pelo apoio, pela paciência e pela compreensão nos momentos de ausência.

Aos novos amigos que fiz durante o mestrado, pelo conhecimento compartilhado e pelas experiências vivenciadas. Todos vocês contribuíram de alguma forma para este momento.

Às amigas Ana e Inajá, meus sinceros agradecimento pelas muitas vezes em que cederam o seu lar para hospedar tanto a mim quanto à amiga Fabiana.

Ao meu professor e orientador, Prof. Dr. Adilson de Lima Tavares, por toda orientação e a atenção que foi dedicada à construção deste trabalho. Suas contribuições, sem dúvida, ajudaram-me a realizar este sonho e a aperfeiçoar ainda mais meus conhecimentos como profissional e pesquisadora. Muito obrigada!

A todos os professores do programa Multi (UnB/UFPB/UFRN), dos quais tive o privilégio de ser aluna durante o mestrado, minha gratidão pelos ensinamentos, atenção e orientações que nos foram dispensados.

Por fim, quero agradecer a todos que, de uma forma ou de outra, também contribuíram para a realização deste sonho. Muito obrigada! 
"A persistência é o menor caminho do êxito".

(Charles Chaplin) 


\section{RESUMO}

A presente pesquisa tem o objetivo de avaliar a evolução da capacidade de classificação das empresas do mercado acionário brasileiro em grupos de melhores e piores alternativas de investimentos, a partir de informações contábeis após a adoção das Normas Internacionais de Contabilidade. Para alcançar o objetivo proposto, foram utilizados 14 índices econômico-financeiros como proxies para discriminar as empresas, os quais foram escolhidos mediante verificação dos índices mais utilizados em pesquisas científicas brasileiras no período de 2010 a 2014. A amostra desta pesquisa é composta pelas empresas do segmento de Governança Corporativa da BM\&FBovespa,totalizando 98 empresas que se mantiveram constantes no período de 2010 a 2014. Inicialmente, a amostra de empresas de cada ano foi ordenada de acordo com a real variação do valor de mercado a fim de classificar as empresas com maior agregação de valor no grupo "Vencedoras" (primeiro terço da amostra), bem como aquelas com menor agregação de valor no grupo das "Perdedoras" (terceiro terço da amostra). A fim de analisar a capacidade preditiva da informação contábil, foi utilizada a técnica de análise discriminante para segregar as empresas nos dois grupos propostos em cada exercício social e avaliar a evolução dos níveis de acertos a partir dos índices econômico-financeiros. Para tanto, as amostras de cada ano foram segregadas em duas subamostras: uma amostra de análise, que foi utilizada para estimar a função discriminante, e a amostra de teste, que valida as funções estimadas em casos não utilizados. A classificação prevista pela análise discriminante foi então comparada com a classificação real do valor de mercado, gerando os níveis de acertos em cada exercício. Os resultados apontaram que as funções discriminantes estimadas com o uso de índices econômico-financeiros evidenciaram uma evolução na capacidade preditiva de classificar as empresas do segmento de Governança Corporativa nos dois grupos propostos, uma vez que alcançaram níveis de acertos de 64,5\%, 74,2\%, 90,3\%, 77,4\% e 93,3\% no período de 2010 a 2014, respectivamente. Adicionalmente, os índices considerados significativos para estimações das funções foram: Crescimento das vendas, Liquidez Geral, Margem Ebtida, Liquidez Corrente, Q de Tobin, Giro do Ativo, ROE, PCCT, Book-to-market.

Palavras-chave: Capacidade Preditiva. Análise discriminante. Índices econômicofinanceiros. 


\begin{abstract}
This study aims to assess the evolution of the classification capacity of companies in the Brazilian stock market in the best groups and worst investment alternatives, from accounting information after the adoption of International Accounting Standards. To achieve the proposed objective, we used 14 economic and financial indicators as proxies to discriminate against companies, which were chosen by checking the most used indexes in Brazilian scientific research in the period 2010 to 2014. The sample of this research consists of the companies segment Corporate Governance of BM\&FBovespa, totaling 98 companies remained constant in the period 2010 to 2014. Initially, the sample of firms each year was ordered according to the actual variation in the market value to rank companies more adding value in the group "Winning" (first third of the sample) and those with lower added value in the group of "win" (third third of the sample). In order to test the predictive ability of accounting information, we used discriminant analysis to segregate companies in the two proposed groups in each fiscal year and assess the evolution of hit levels from the economic and financial ratios. For this purpose, samples of each year were divided into two samples: an analysis sample, which was used to estimate the discriminant function, and the test sample, that test functions estimated in unused cases. The classification provided by the discriminant analysis was then compared with the actual classification of the market value, generating the hit levels each year. The results showed that the discriminant function estimated using economic and financial ratios showed an increase in predictive ability to rank companies in the segment of corporate governance in the two proposed groups, as achieved successes levels of $64.5 \%, 742 \%, 90.3 \%, 77.4 \%$ and $93.3 \%$ in the period 2010-2014, respectively. In addition, the indices considered significant for estimation of the functions are: Sales growth, overall liquidity, EBITDA margin, Current Liquidity, Tobin's Q, the Asset Turnover, ROE, PCCT, Book-to-market.
\end{abstract}

Keywords: Predictive Capacity. Discriminant Analysis. Economic and Financial Ratios. 


\section{LISTA DE ABREVIATURAS E SIGLAS}

AFF

AHP

BM\&FBovespa

$\mathrm{CPC}$

DEA

IBGC

IFRS

IGC

SPSS

VIF
Análise Financeira Fundamentalista

Analytic Hierarchy Process

Bolsa de Valores, Mercadoria e Futuros de São Paulo

Comitê de Pronunciamento Contábil

Data Envelopment Analysis

Instituto Brasileiro de Governança Corporativa

International Financial Reporting Standards

Índice de Governança Corporativa

Statistical Package for the Social Sciences

Fator de Inflação da Variância 


\section{LISTA DE QUADROS}

Quadro 1 - Periódicos consultados

Quadro 2 - Índices selecionados nesta pesquisa

Quadro 3 - Códigos identificadores dos índices econômico-financeiros

Quadro 4 - Empresas participantes deste estudo 


\section{LISTA DE TABELAS}

Tabela 1 - Impacto dos Outliers nas amostras anuais

Tabela 2 - Segregação das amostras anuais

Tabela 3 - Resultados do teste Kolmogorov-Smirnov nas amostras de análise

Tabela 4 - Resultado dos Testes de Multicolinearidade nas amostras anuais

Tabela 5 - Resultados do Teste Box's M nas amostras anuais

Tabela 6 - Resumo do processamento das amostras de análise

Tabela 7 - Teste de igualdade de médias de grupos em cada exercício social

Tabela 8 - Resultado das Variáveis Inseridas em cada etapa por exercício social

Tabela 9 - Detalhamento das Variáveis inseridas por etapa em cada exercício

Tabela 10 - Coeficientes das funções discriminantes canônicas

Tabela 11 - Detalhamento dos Coeficientes das funções de classificação por exercício

Tabela 12 - Funções de centroides dos grupos

Tabela 13 - Probabilidades a priori para os grupos

Tabela 14 - Ponto de corte de cada amostra por exercício

Tabela 15 - Resultados da classificação em cada exercício social

Tabela 16 - Resultados do teste $Q$ de Press

Tabela 17 - Detalhamento da Avaliação da função discriminante

Tabela 18 - Resumo das variáveis e níveis de acertos por exercício

Tabela A1 - Empresas da amostra no exercício de 2010

Tabela A2 - Empresas da amostra no exercício de 2011

Tabela A3 - Empresas da amostra no exercício de 2012

Tabela A4 - Empresas da amostra no exercício de 2013

Tabela A5 - Empresas da amostra no exercício de 2014

Tabela A6 - Detalhamento da Classificação de empresas - Exercício 2010

Tabela A7 - Detalhamento da Classificação de empresas - Exercício 2011

Tabela A8 - Detalhamento da Classificação de empresas - Exercício 2012

Tabela A9 - Detalhamento da Classificação de empresas - Exercício 2013

Tabela A10 - Detalhamento da Classificação de empresas - Exercício 2014 


\section{SUMÁRIO}

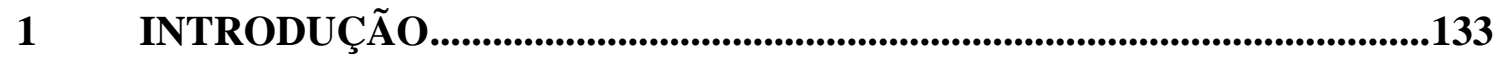

2 OBJETIVOS …….....................................................................................15

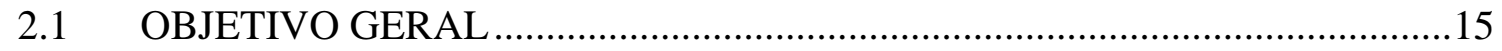

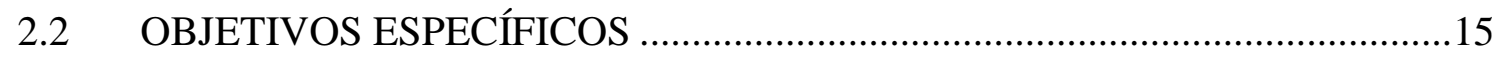

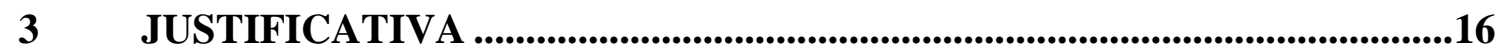

4 REVISÃO DA LITERATURA....................................................................18

4.1 A CONTABILIDADE E SUA PERSPECTIVA INFORMACIONAL ...............18

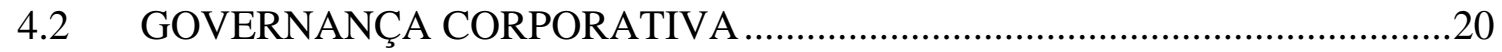

4.3 ANÁLISE ECONÔMICO-FINANCEIRA …………………………………......

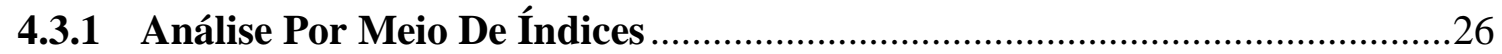

4.4 ESTUDOS ANTERIORES SOBRE PREVISÕES DA SITUAÇÃO FINANCEIRA 29

5 METODOLOGIA......................................................................................35

5.1 SELEÇÃO DOS ÍNDICES E COLETA DE DADOS ……………………........395

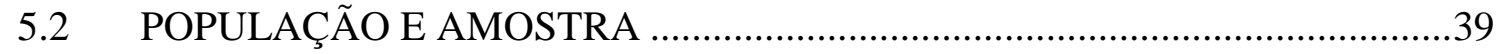

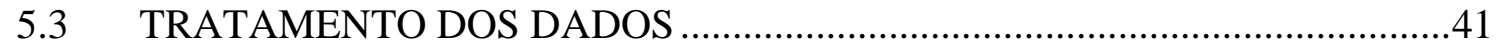

5.3.1 Observações Atípicas (OUTLIERS) …………....................................................41

5.3.2 Segregação das Amostras ............................................................................422

5.3.3 Análise Discriminante .....................................................................................43

6 ANÁLISE DOS RESULTADOS ...............................................................477

6.1 PREMISSAS DA ESTATÍSTICA DA ANÁLISE DISCRIMINANTE ............477

6.2 ESTIMAÇÃO DA FUNÇÃO DISCRIMINANTE ............................................50

6.3 VALIDAÇÃO DA FUNÇÃO DISCRIMINANTE.............................................60

6.4 INTERPRETAÇÃO DO MODELO ANÁLISE DISCRIMINANTE ................655

7. CONSIDERAÇÕES FINAIS .............................................................................688

REFERÊNCIAS ..........................................................................................71

APÊNDICE A - LISTA DE ARTIGOS CONSULTADOS NESTA PESQUISA..777 APÊNDICE B - CLASSIFICAÇÃO REAL DAS EMPRESAS ENTRE "VENCEDORAS" E "PERDEDORAS"...................................................................844 APÊNDICE C - CLASSIFICAÇÃO DAS EMPRESAS PELO MÉTODO DE ANÁLISE DISCRIMINANTE. 


\section{INTRODUÇÃO}

A informação é a peça chave para o processo de comunicação e para o desenvolvimento das relações, seja entre pessoas, entidades ou pessoas e entidades (BARBOSA; SILVA, 2014). No contexto de mercado, por exemplo, a informação contábil constitui-se como importante instrumento para avaliação de empresas e possíveis investimentos.

Segundo o Pronunciamento conceitual básico (CPC 00-R1, 2011), uma informação relevante nas demonstrações contábeis é aquela capaz de fazer diferença na tomada de decisão, a qual pode auxiliar os analistas na previsão de resultados futuros ou confirmar ou, ainda, corrigir expectativas anteriores. Além da relevância, outra característica fundamental à informação contábil é a representação fidedigna, isto é, para uma informação contábil-financeira representar com fidedignidade o fenômeno que se propõe a representar é necessário que ela seja completa, neutra e livre de erros.

Como a função primordial da Contabilidade é a de fornecer informação contábil que atenda aos diversos interesses dos grupos de usuários, sejam eles acionistas, administradores, governo ou pessoas físicas, a informação contábil, para ser útil, precisa ser concomitantemente relevante e representar com fidedignidade a realidade reportada.

Visando contribuir com essa perspectiva informacional da Contabilidade, no Brasil, o processo de adoção das normas internacionais de contabilidade (IFRS) teve, entre outros, o objetivo de contribuir para a uniformização dos relatórios contábilfinanceiros, e, consequentemente, para a relevância e confiabilidade das informações colocadas à disposição do mercado pelas companhias. Além disso, espera-se que a adoção dos IFRS proporcione a melhoria da qualidade das informações divulgadas, uma vez que a informação contábil pode ser comparável, verificável, tempestiva e compreensível.

Essas preocupações surgiram diante dos recentes escândalos e fraudes contábeis envolvendo corporações norte-americanas, como a Enron, a WorldCom e Imclone Systems, que colocaram em xeque a confiabilidade das informações contábeis e das auditorias externas e o papel dos conselhos de administração dessas companhias (MARTINS et al., 2012). Além disso, esses escândalos resultaram na aprovação da Lei Sarbanes-Oxley, com o objetivo de proporcionar maior confiabilidade e transparência nos resultados das empresas, assim como punições severas contra fraudes corporativas (SILVA et al., 2011). 
Entretanto, os escândalos e fraudes contábeis envolvendo instituições financeiras não são exclusividade dos Estados Unidos, pois, no Brasil, ocorreram escândalos envolvendo Bancos nacionais que tiveram repercussão internacional, o que despertou a preocupação de investidores quanto à confiabilidade das informações financeiras divulgadas pelas empresas brasileiras (SILVA et al., 2011; MARTINS et al., 2012).

Em razão disso, o Brasil preocupou-se em criar um ambiente propício para aqueles investidores que buscam investir seu capital em ambientes confiáveis e favoráveis, resultando na atuação de importantes agentes de mercados de capitais e na elaboração de códigos de conduta com o intuito de fornecer incentivos, mecanismos e recomendações de melhores práticas de governança (SILVA et al., 2011).

A BM\&FBovespa, atendendo à necessidade do mercado de capitais e contribuindo para uma maior divulgação dos benefícios em prol da adoção das práticas de governança, tomou a iniciativa de criar, no ano de 2000, os níveis diferenciados de Governança Corporativa (MELO et al., 2014). Ao participar desse segmento, as empresas aderem às regras de governança corporativa, cujo Código de Boas Práticas, elaborado pelo Instituto Brasileiro de Governança Corporativa (IBGC), possui como princípios básicos: a transparência, a prestação de contas, a equidade e a responsabilidade social corporativa (IBGC, 2009).

Nesse contexto, a literatura possui uma gama de estudos que buscam relacionar as informações contábeis e o mercado de capitais com a finalidade de testar a capacidade de influenciar a tomada de decisão dos investidores (VIEIRA et al., 2011; CATAPAN et al., 2013; MOTA, TAVARES, 2015). Nesses estudos, verifica-se que uma das formas de se analisar as alternativas de investimento no mercado de ações é através da técnica de Análise Discriminante, a qual busca segregar previamente grupos de melhores e piores alternativas de investimentos a partir das informações contábilfinanceiras (TAVARES, 2010; ORO et al., 2012; TEIXEIRA et al., 2013; SERRA et al., 2014; ARTUSO, CHAVES NETO, 2014; HIJAZI et al., 2015).

Dessa forma, esta pesquisa busca responder à seguinte questão de pesquisa:

Como tem evoluído a capacidade de classificação das empresas do mercado acionário brasileiro em grupos de melhores e piores alternativas de investimentos, a partir de índices econômico-financeiros, após a adoção das Normas Internacionais de Contabilidade? 


\section{OBJETIVOS}

\subsection{OBJETIVO GERAL}

Avaliar a evolução da capacidade de classificação das empresas do mercado acionário brasileiro em grupos de melhores e piores alternativas de investimentos, a partir de índices econômico-financeiros, após a adoção das Normas Internacionais de Contabilidade.

\subsection{OBJETIVOS ESPECÍFICOS}

a) Classificar, através de um ranking anual, as companhias a partir da variação do valor de mercado no período de 2010 a 2014.

b) Levantar os índices econômico-financeiros utilizados em pesquisas científicas publicadas no período de 2010 a 2014, selecionando, através da frequência, aqueles índices mais utilizados e que servirão como proxies para discriminar as empresas.

c) Aplicar a técnica de Análise Discriminante aos dados anuais na segregação em grupos de melhores e piores alternativas de investimento no período de 2010 a 2014.

d) Verificar a evolução do nível de acertos na classificação das empresas em grupos de melhores e piores alternativas de investimento no período de 2010 a 2014. 


\section{JUSTIFICATIVA}

A promulgação da Lei ${ }^{\circ}$ 11.638/2007 deu início ao processo de adoção dos IFRS no Brasil. A partir dessa lei, os relatórios contábil-financeiros, elaborados segundo o padrão contábil internacional, devem apresentar a relevância, como característica qualitativa fundamental, e a confiabilidade das informações colocadas à disposição do mercado pelas companhias.

O processo de convergência no Brasil ocorreu em duas fases: durante os anos 2008 e 2009, houve aplicação parcial dessas novas normas, e, somente a partir do ano 2010, efetivou-se a aplicação das normas com todos os CPCs vigentes em conformidade com os padrões internacionais (IFRS).

De forma paralela ao processo de convergência, emergem, no Brasil, os conceitos e os códigos das boas práticas de Governança Corporativa, que possuem como pilares a transparência, a equidade, a prestação de contas e a responsabilidade social corporativa. Nesse contexto, destacam-se diversas pesquisas que ilustram a adoção da estrutura de Governança Corporativa e sua relação positiva com os resultados financeiros das empresas (FERREIRA et al., 2013).

Assim, a contribuição deste trabalho reside, primeiramente, em continuar a pesquisa de Tavares (2010), o qual sugeriu a realização do estudo no período após a adoção das normas internacionais de contabilidade. Segundo, este estudo propõe-se a avaliar a evolução na capacidade preditiva das informações contábeis das empresas brasileiras, elaboradas segundo o padrão contábil internacional (IFRS). Especificamente, espera-se que tais informações sejam preditivas para a tomada de decisões entre grupos de Melhores e Piores alternativas de investimentos entre empresas pertencentes aos níveis de Governança Corporativa da BM\&FBovespa.

Silva (2010) e Matarazzo (2010) reiteram que, em benefício da própria análise contábil-financeira, faz-se necessária a utilização de determinados instrumentos quantitativos com fins de auxiliar no emprego dos resultados dessa análise no processo de tomada de decisão. Dessa forma, é preciso aplicar técnicas que integrem os índices da análise contábil-financeira, de modo a organizar e condensar a informação, haja vista a quantidade de índices e a diversidade de combinações possíveis para análise de desempenho.

Em tal diversidade de índices na literatura contábil é que reside outra contribuição deste estudo, visto que explorará, através das recentes pesquisas 
científicas, os índices mais utilizados pelos pesquisadores para mensurar o desempenho econômico-financeiro das empresas.

Portanto, este estudo justifica-se pela importância em avaliar a evolução da capacidade preditiva das informações contábeis no mercado acionário brasileiro, bem como por avaliar um segmento do mercado que possui essencialmente maior nível de disclosure de informações voltadas a proteção de seus investidores. 


\section{REVISÃO DA LITERATURA}

\subsection{A CONTABILIDADE E SUA PERSPECTIVA INFORMACIONAL}

Não há como tratar de informação contábil sem que se defina a própria Contabilidade. A FEA/USP (2010, p. 15) define a Contabilidade:

Como Ciência Social Aplicada, a Contabilidade tem a função de captar, registrar, acumular, resumir e interpretar os fenômenos que afetam as situações patrimoniais, financeiras e econômicas de qualquer ente, seja pessoa Física, entidade sem fins lucrativos ou Pessoa de Direito Público.

A partir desse conceito, verifica-se que um dos objetivos da Contabilidade é fornecer informação contábil que atenda aos diversos interesses dos grupos de usuários, sejam eles acionistas, administradores, governo ou pessoas físicas.

Segundo Yamamoto e Salotti (2006), a informação contábil é aquela que altera o estado da arte do conhecimento de seu usuário em relação à entidade que reporta a informação e, a partir de interpretações, utiliza-a na solução de problemas. A partir desse conceito, Cruz (2010) complementa que a informação contábil tem o poder confirmatório ou de transformação da percepção dos usuários com relação à capacidade econômica da entidade, e, por isso, pode ser utilizada no processo de tomada de decisões.

O processo de adoção das normas internacionais de contabilidade no Brasil teve, entre outros, o objetivo de contribuir para a uniformização dos relatórios contábilfinanceiros e, consequentemente, para a confiabilidade das informações colocadas à disposição do mercado pelas companhias.

Com a promulgação da Lei 11.638/07, foi possível dar-se início ao processo de adoção dos IFRS no Brasil, o qual ocorreu em duas etapas. Para as demonstrações dos anos 2008 e 2009, houve aplicação parcial das novas normas, as quais correspondiam à adoção de apenas 14 pronunciamentos técnicos (CPCs) emitidos em correlação às IFRS. A segunda etapa ocorreu a partir do ano 2010, quando se efetivou o processo de aplicação das normas com todos os CPCs vigentes (SILVA; NARDI, 2014).

Entre essas normas encontra-se o Pronunciamento Conceitual Básico (CPC 00R1, 2011), que tem por objetivo dar suporte à harmonização das normas contábeis e dos procedimentos relacionados à apresentação das demonstrações contábeis, de modo que 
auxilie a interpretação das informações contábil-financeiras por todos os usuários, auditores e interessados nas demonstrações contábeis.

Esse pronunciamento salienta que, para a informação contábil ser útil no processo de tomada de decisões, é necessário que, antes, a informação possua as características qualitativas fundamentais da informação contábil, isto é, possua relevância e represente com fidedignidade o que se propõe a representar. Ademais, a informação contábil-financeira pode ser melhorada se possuir as características qualitativas de melhoria: comparabilidade, verificabilidade, tempestividade $\mathrm{e}$ compreensibilidade.

Em linhas gerais, entende-se que as informações contidas nas demonstrações contábeis têm caráter relevante quando são capazes de fazer diferença na tomada de decisão, isto é, quando ajudam os usuários a prever resultados de eventos do futuro ou para confirmar ou corrigir expectativas anteriores (CARVALHO et al., 2013).

Com isso, a adoção das normas internacionais de Contabilidade deve proporcionar maior qualidade às demonstrações contábeis de empresas brasileiras, maior acurácia na evidenciação da situação econômico-financeira, bem como trazer maior oportunidade e relevância à informação contábil (SILVA; NARDI, 2014).

Desse modo, dentro da perspectiva informacional e de relevância das informações, destaca-se que os relatórios contábil-financeiros têm o objetivo de fornecer informações acerca da entidade que sejam úteis à tomada de decisão dos usuários. Os relatórios fornecem informações acerca da posição patrimonial e financeira da entidade, que incluem as informações sobre recursos econômicos, reivindicações e as mudanças nos recursos (CPC 00-R1, 2011).

Segundo Cruz e Lima (2010), a disponibilidade de informações ocorre através da evidenciação de relatórios corporativos que podem englobar tanto informações obrigatórias por lei quanto voluntárias, quantitativas ou qualitativas, positivas ou não, além de diversas naturezas.

Com isso, outro ponto importante na perspectiva informacional é a divulgação de informações, ou também chamada, nas pesquisas científicas, de disclosure ou evidenciação das informações, que compreende a ampla disponibilidade de informações específicas da companhia para aqueles que estão de fora da organização (BUSHMAN et al., 2004).

Sendo o assunto em foco a informação contábil, percebe-se a relação da Governança Corporativa com a evidenciação - sinônimo de divulgação de informação - 
, a transparência e o disclosure (GALLON et al., 2007), na qual tem-se a informação como ponto chave de qualquer relação existente, seja entre pessoas, entidades ou ainda entre pessoas e entidades.

\subsection{GOVERNANÇA CORPORATIVA}

A governança corporativa pode ser definida como o conjunto de mecanismos que possibilita aos fornecedores de recursos a garantia de obtenção de retorno sobre seu investimento (SCHLEIFER; VISHNY, 1997). Corroborando esse entendimento, Leal e Saito (2003) acrescentam que a Governança Corporativa é um conjunto de regras, práticas e instituições que determinam a forma como os administradores devem agir para melhor atender aos interesses das partes relacionadas, considerando que, na maioria dos casos no Brasil, não existe uma separação entre a administração e o controle das empresas, ocorrendo o conflito de interesses entre acionistas minoritários e acionistas controladores.

Jensen e Meckling (1976) afirmam que a separação entre as funções dos gestores e a propriedade da empresa possibilita os conflitos de agência, onde os agentes internos tentam maximizar a utilidade expropriando os ganhos dos agentes externos, com menos acesso às informações sobre a firma. A assimetria de informação ocorre quando um dos participantes de um negócio possui melhores informações do que outros participantes (SCOTT, 2003 apud OLIVEIRA et al., 2014).

Nesse sentido, o foco da Governança Corporativa centra-se em minimizar os problemas de agência e buscar assegurar que os acionistas minoritários recebam informações confiáveis sobre o valor da firma, em que as informações contábeis podem ser consideradas como um dos instrumentos para a redução de conflitos (BUSHMAN; SMITH, 2003).

Bushman e Smith (2001) posicionam a Contabilidade como meio de promoção da Governança Corporativa nas organizações ao disponibilizar informações úteis aos seus usuários e contribuir para a redução da assimetria informacional. A principal forma de acompanhar o desempenho das empresas é através dos relatórios contábeis, cujas informações são relevantes e espera-se que demonstrem a realidade econômicofinanceiro da empresa, a fim de dar suporte à tomada de decisões (OLIVEIRA et al., 2014). 
Os escândalos financeiros envolvendo grandes corporações nacionais e internacionais têm chamado grande atenção do mercado acionário, uma vez que esses fatos afetaram a confiança dos investidores sobre o real desempenho dessas corporações. Com isso, reconhecendo a necessidade de um ambiente propício para aqueles investidores que buscam investir seu capital em ambientes confiáveis e favoráveis, o Brasil criou um segmento específico para as empresas interessadas em adotar as práticas de Governança Corporativa (SILVA et al., 2011).

Segundo o Instituto Brasileiro de Governança Corporativa - IBGC (2010), as boas práticas de Governança Corporativa proporcionam aos proprietários a gestão estratégica da empresa e a monitoração da direção executiva, buscando a proteção de acionistas minoritários contra os interesses oportunistas de acionistas controladores. Esse fato representa um dos fundamentos que norteiam os seguintes Princípios de Governança Corporativa: transparência, equidade, prestação de contas (accountability) e responsabilidade corporativa (IBGC, 2010).

Os mecanismos de Governança Corporativa são classificados em mecanismos internos, constituídos pelo conselho de administração e estrutura de propriedade, e os externos, como o mercado, o sistema legal e regulatório e as instituições (DENIS; MC CONNELL, 2003).

Desse modo, fica claro que um dos objetivos da Governança Corporativa é proteger os acionistas e credores através do monitoramento do comportamento da gestão e da tomada de decisão para que não haja expropriação pelos agentes da organização (ALMEIDA et al., 2010).

Os autores Catapan et al. (2013) entendem que os atributos de GC têm o objetivo de induzir os tomadores de decisões a terem atitudes voltadas a maximizar o valor da empresa e alinhar interesses de partes conflitantes. Pensando nisso, os agentes atuantes no mercado acionário adotaram algumas medidas, como, por exemplo, as alterações na Legislação Societária (Lei das S/A - no 6.404/76), que proporcionaram maior proteção aos acionistas minoritários, e a criação dos níveis diferenciados de Governança Corporativa pela BM\&FBovespa no ano de 2000.

A BM\&FBovespa possui os seguintes níveis diferenciados de Governança, os quais possuem determinadas regras específicas:

a) O Novo Mercado é o mais elevado padrão de listagem, em que as empresas se comprometem com a adoção das boas práticas de Governança e disclosures adicionais daquilo que é exigido pela legislação, efetivados através de 
contratos de participação entre a companhia, controladores, administradores e a BM\&FBovespa;

b) O Nível 2, além de adotar um conjunto amplo de boas práticas de Governança e de direitos aos acionistas minoritários, compromete-se com as exigências do Nível 1;

c) No Nível 1, as companhias devem buscar as melhorias na prestação de informações aos mercados e com a divisão acionária;

d) O Bovespa Mais segue o mesmo princípio de elevados padrões de Governança e transparência no mercado, ao passo que as empresas iniciantes no Mercado têm o direito de listar-se na Bolsa e oferecer, em até 7 anos, sua oferta pública de ações;

e) O Bovespa Mais Nível 2 acrescenta àquelas regras do Bovespa Mais o poder de negociação de ações preferenciais (PN), além de ações ordinárias $(\mathrm{ON})$.

Dessa forma, a BM\&Fbovespa atribuiu estratégias próprias a serem cumpridas para que as empresas participem desses segmentos, resultando em maior transparência para os investidores. Além disso, o conjunto de mecanismos de incentivo e controle, internos e externos à companhia estabelecidos pela governança corporativa, contribui para a redução dos custos decorrentes dos problemas de agência e, paralelamente, para a redução da assimetria informacional, bem como para o fornecimento de informações contábeis de maior qualidade (OLIVEIRA, et al. 2014).

Aliado a esses níveis diferenciados de Governança Corporativa, a BM\&FBovespa criou, em 2001, o índice de ações de Governança Corporativa Diferenciada (IGC) com o objetivo de medir o desempenho da carteira teórica composta por ações de companhias que apresentem bons níveis de governança. Entretanto, uma das regras para que as empresas participem do IGC é não possuir participação superior a $20 \%$ da carteira do índice.

Nesse contexto, acredita-se que a otimização do desempenho de uma organização se dá ao protegerem-se todas as partes interessadas, quer sejam investidores, empregados ou credores, facilitando o acesso ao capital, que é a finalidade do conjunto de práticas de Governança Corporativa.

Com isso, a adoção das regras de Governança visa a reduzir os riscos para os investidores, concedendo os direitos e garantias assegurados aos acionistas (OLIVEIRA et al., 2014). Além disso, as informações contábeis divulgadas podem ser consideradas 
um dos meios para a redução de conflitos (assimetria informacional) entre acionistas controladores, participantes do mercado e gestores da companhia (BUSHMAN; SMITH, 2003).

No meio acadêmico, têm-se desenvolvido vários estudos partindo do pressuposto de que os mecanismos e as boas práticas de Governança Corporativa influenciam o desempenho de empresas em termos econômico e financeiro (VIEIRA et al. 2011; KIMURA et al., 2012; MARTINS et al., 2012; CATAPAN et al., 2013; MELO et al., 2014).

A pesquisa dos autores MELO et al. (2014) buscou avaliar a eficiência econômico-financeira das companhias integrantes do IGC, mostrando um panorama das práticas de governança adotadas pelas companhias e avaliando o quanto a governança corporativa pode influenciar na eficiência de uma companhia. Os resultados demonstraram que a maioria das companhias não apresentou eficiência econômicofinanceira, apesar de que, por meio da análise envoltória dos dados (DEA), foi confirmada a eficiência de 16 companhias no período de 2008 a 2010.

De forma semelhante, os autores Catapan et al. (2013) buscaram verificar o efeito da Governança Corporativa sobre as variáveis de desempenho de natureza contábil e de mercado em empresas brasileiras, entretanto, os resultados obtidos não indicaram efeito estatisticamente significante.

Por sua vez, o estudo de KIMURA et al. (2012) busca avaliar como o desempenho, medido pela lucratividade das empresas, está relacionado com as macro variáveis ligadas à governança no âmbito brasileiro, tais como: (i) nível de disclosure de informações no mercado; (ii) nível de enforcement de leis; e (iii) mecanismos de proteção de acionistas e credores. Nesse caso, os resultados apontaram que: por um lado, tanto a assimetria informacional ligada à falta de disclosure sobre lucros e salários quanto a proteção ao credor por afetar a sensibilidade da lucratividade têm uma influência sobre o coeficiente da dificuldade financeira, uma vez que é através da mensuração da tangibilidade da empresa que se possibilita o acesso a financiamentos e empréstimos; por outro lado, os níveis de burocracia, corrupção e imposição da lei não são relevantes para a lucratividade da empresa.

Martins et al. (2012) tiveram o objetivo de identificar as principais características e competências dos conselhos de administração dos bancos brasileiros e relacioná-las com o desempenho financeiro e a governança corporativa dessas organizações. Seus resultados sugerem que as competências que apresentaram relações 
com o desempenho foram: fiscalizar a gestão dos diretores, autorizar a prestação de garantias e obrigações a terceiros e escolher destituir auditores independentes.

Outro estudo foi realizado pelos autores Vieira et al. (2011), que também buscaram verificar se a adoção das práticas de governança corporativa alteraria a estrutura de capital e o desempenho das empresas. Porém os resultados indicaram pouca influência exercida pelas práticas de governança nas variações de desempenho e na estrutura de capital das empresas participantes da amostra.

\subsection{ANÁLISE ECONÔMICO-FINANCEIRA}

A partir da década de 1960, a pesquisa em Contabilidade passou de uma abordagem normativa para uma perspectiva baseada na informação, a qual vê a contabilidade como fornecedora de informações úteis ao processo decisório dos usuários.

Em 1968, os autores Ball e Brown foram os primeiros pesquisadores que buscaram fornecer evidência empírica para verificar se existia relação entre as informações contábeis e o desempenho das empresas no mercado financeiro. Ball e Brown (1968) verificaram que os resultados anormais começaram a crescer alguns meses antes dos anúncios dos lucros e atribuíram outros fatores, além da contabilidade, a este resultado.

O estudo de Ball e Brown (1968) e a perspectiva baseada na informação contribuíram para disseminar a utilidade da informação contábil para a análise econômico-financeira e também para a tomada de decisões dos seus usuários.

Diante do mercado competitivo, as empresas buscam a maximização de seu valor no mercado, enquanto os proprietários esperam que seus investimentos tenham um retorno compatível com o risco assumido por meio da geração de resultados econômicos e financeiros (HOJI, 2003). Nesse contexto, as análises econômica e financeiras tornam-se uma ferramenta imprescindível para o gerenciamento empresarial e para a sobrevivência do negócio.

Um aspecto intrínseco às demonstrações contábeis é o pressuposto da comparabilidade, tendo em vista que os usuários podem comparar as demonstrações contábeis de uma entidade ao longo do tempo a fim de verificar tendências na sua posição financeira e no seu desempenho (CUNHA et al., 2013). 
A análise financeira pode-se realizar através das informações extraídas das demonstrações contábeis e de todo o conhecimento sobre a organização e a atividade que ela desempenha, de forma que se possam abranger e avaliar: a capacidade de remunerar os investidores, a capacidade de pagamento a partir da geração de caixa, o nível de endividamento, a necessidade de capital de giro e sua relação com as políticas operacionais, bem como o impacto das decisões estratégicas relacionadas a investimentos e financiamentos (SILVA, 2010).

Corroborando com o autor acima, Bastos (2008) evidencia outras informações que os usuários da informação contábil podem extrair a partir da análise das demonstrações contábeis. Por exemplo: os analistas podem analisar a rentabilidade do investimento; os fornecedores e financiadores da empresa podem observar a capacidade de pagamento de uma entidade; os bancos e as instituições de crédito podem utilizar as demonstrações contábeis pra concessão de financiamento e empréstimos às empresas, entre outros.

Sabendo de sua importância e abrangência, Martins (2005 apud SOARES et al., 2011) cita alguns procedimentos necessários para se realizar uma boa análise das demonstrações contábeis. O primeiro deles é analisar o parecer de auditoria, o qual vai atestar sobre as demonstrações contábeis e a veracidade das informações. Em seguida, deve-se conhecer o negócio da empresa e os critérios contábeis aplicáveis a essa organização. Depois, deve-se analisar a liquidez e a rentabilidade da empresa, uma vez que tanto a incapacidade de remunerar o capital próprio quanto de saldar as obrigações pode levar a empresa à falência.

Os autores Callado et al. (2008) acreditam que analisar o desempenho econômico e financeiro é o processo que busca nas demonstrações contábeis as informações necessárias para auxiliar a decisão dos gestores e analistas, e ainda possibilita focar pessoas e recursos na direção das estratégias planejadas.

Dessa forma, o objetivo fundamental da análise econômica e financeira é relatar uma opinião acerca do desempenho de uma empresa durante determinado período, além de disponibilizar informações que auxiliem no diagnóstico sobre a situação financeira da empresa analisada (SOARES et al., 2011)

A análise das demonstrações contábeis desenvolve-se por meio de uma variedade de técnicas, de modo que um único número extraído das demonstrações contábeis pode ser combinado com múltiplas informações para produzir medidas que podem ser comparadas por empresas e com o passar dos anos (BASTOS, 2008). 
Podem-se citar vários modelos e técnicas de análise que são utilizados para se entender a situação financeira de uma entidade e obter informações que justificarão o processo de tomada de decisões, tais como: análise horizontal, análise vertical, análise por meio de índices, análise dinâmica do capital de giro, modelos de previsão de falência, entre outros.

Nesse contexto, entre as diversas técnicas disponíveis na literatura para o desempenho de uma empresa, destaca-se a Análise de Índices Econômico e Financeiros, a qual utiliza as demonstrações contábeis como fonte de dados e informações, transformados em índices, para possibilitar e identificar a evolução do desempenho econômico e financeiro das empresas e efetuar análises para futuras projeções e planejamentos (CAMARGOS; BARBOSA, 2005).

\subsubsection{Análise por meio de Índices}

A técnica de análise das demonstrações contábeis por meio de índices é utilizada há mais de um século, pois, segundo o autor Myer (1976), há evidências de que, em 1908, os banqueiros dos Estados Unidos analisavam a liquidez das entidades como exigência para a concessão de créditos.

Contudo, somente em 1919 essa análise por meio de índices ficou conhecida, pois Alexander Wall, considerado o pai da análise de balanços, criticou os banqueiros por utilizarem apenas o índice de liquidez como base para tomada de decisões. A partir daí, ficou evidente que, para avaliar a situação econômica e financeira de uma empresa, faz-se necessário considerar outras relações além de ativos e passivos coerentes (BASTOS, 2008; TAVARES; SILVA, 2012).

Os índices financeiros surgiram a partir da análise das demonstrações financeiras, visando evidenciar a relação entre os recursos aplicados de uma empresa e o fluxo financeiro (PENMAN, 1991; LIEZ; MARANVILLE, 2008). Além disso, Lyra (2008) menciona que os índices econômico-financeiros têm a função de medir, comparar e projetar desempenhos, sejam eles econômicos, financeiros e patrimoniais.

A análise das demonstrações por meio de índices é tradicionalmente utilizada por credores, investidores, agências reguladoras e concorrentes, uma vez que permite a estes avaliar a saúde financeira e o desempenho organizacional, além de extrair tendências e comparar os índices com padrões pré-estabelecidos. Ademais, fornece 
bases para inferir tendências futura por meio de informações passadas (IUDÍCIBUS, 2010).

De acordo com Silva (2010), os índices são relações entre contas ou grupos de contas das demonstrações contábeis, que possuem como objetivo o fornecimento de informações que não são explicitamente visíveis nas demonstrações.

Para tanto, os índices devem possuir as seguintes características básicas a fim de garantir uma análise consistente e confiável, são elas: a) objetividade - para permitir sua avaliação; b) mensurabilidade - devem ser quantificáveis em determinada escala; c) compreensibilidade - deve ter significado compreensível; d) comparabilidade - devem ser comparáveis entre empresas e ao longo do tempo (LYRA, 2008).

Este estudo relaciona de forma breve os tradicionais índices econômicofinanceiros e classifica-os, segundo Assaf Neto (2010), nos seguintes grupos: liquidez e atividade, endividamento e estrutura, rentabilidade e análise das ações:

- Índices de Liquidez - têm o objetivo de medir a capacidade de pagamento (folga financeira) da empresa e são baseados na relação entre ativos e passivos (KASSAI, 2002).

- Índices de Rotatividade - analisam os ciclos operacionais e financeiros da empresa, os quais subdividem em prazo médio de estocagem, pagamento a fornecedores e recebimento de clientes.

- Índices de Endividamento e Estrutura - têm por fim mensurar a composição das fontes passivas de recursos da empresa, distinguindo entre capital próprio e de terceiros.

- Índices de Rentabilidade - avaliar os resultados auferidos por uma empresa em relação a determinados parâmetros. Em outras palavras, Kassai (2002) explica que envolvem as relações entre o retorno comparado ao Ativo (ROA), ou ao Patrimônio líquido (ROE), ou também ao ativo deduzido dos passivos de funcionamento (ROI). Além da relação entre as vendas com o lucro operacional (Margem operacional) e o lucro líquido (Margem líquida).

- Índices de análise de ações - buscam relacionar as informações contábeis com as informações de mercado, cujos índices mais conhecidos são Lucro por Ação (Lucro líquido/Número de ações) e o Preço/Lucro (Preço de mercado da ação/Lucro por ação). 
Contudo, o autor Lyra (2008) relata, em sua tese de doutorado, algumas críticas a esses índices comumente utilizados. Os índices de Liquidez revelam uma posição estática do passado e como, geralmente, a análise é realizada após a data de fechamento do balanço que originou os dados, estes podem não mais refletir a situação financeira apontada pelo índice. Além disso, é um equívoco considerar que esses índices revelem a capacidade de pagamento, uma vez que são índices que não são extraídos dos fluxos de caixa.

Quanto aos índices de estrutura de capital, este autor identifica uma incompatibilidade de comparação de valores a estes, visto que alguns itens circulantes são registrados a valores de realização, ao passo que os itens de ativo imobilizado e de patrimônio líquido são registrados a valor histórico.

As críticas relacionadas aos índices de rentabilidade estão relacionadas ao fato de esses índices serem compostos de itens extraídos da demonstração do resultado que não consideram o custo de capital próprio, não identificam a capacidade de geração de lucro dos ativos e sofrem influência da idade dos ativos.

Por sua vez,os índices de atividade sofrem limitações no cálculo por usuários externos, visto que as demonstrações contábeis não detalham todos os dados e isso prejudica algumas estimações como: determinar o valor de vendas a prazo de forma objetiva, o valor correto das compras (inclusive as compras a prazo), assim como impossibilita a comparação desses valores aos de fornecedores.

Apesar de existirem tantos índices, não há uma quantidade certa ou ideal de índices para se realizar a análise das demonstrações contábeis. O importante é que seja utilizado um conjunto de índices que permita se conhecer a situação da empresa segundo o enfoque desejado da análise (CUNHA et al., 2013).

Acredita-se, então, que é muito importante que o analista seja seletivo, pois o uso de vários índices pode confundir os usuários e alguns deles podem não possibilitar uma conclusão apropriada (SOUZA et al., 2009). Dessa forma, entende-se que a utilização de vários índices não torna a análise melhor ou mais aprimorada, logo a quantidade de índices a ser utilizada na análise depende essencialmente das informações que o analista deseja obter da empresa (CUNHA et al., 2013).

Diante desse contexto, um dos maiores desafios na implementação de um processo de avaliação de desempenho é a definição de quais índices melhor atendem às necessidades de informação dos seus usuários (MIRANDA; SILVA, 2002). 
Corroborando com Miranda e Silva, o autor Bonfim (2014) considera que a escolha de um indicador de desempenho não é tarefa fácil, pois o processo de mensuração do desempenho deverá envolver a escolha de medidas que reflitam a realidade econômico-financeira, bem como deverá possibilitar o acompanhamento dos resultados de planos e estratégias desenvolvidos para o negócio.

Toni e Tonchia (2001) afirmam que a escolha de um indicador envolve a definição do elemento ou do fenômeno a ser medido, bem como a verificação da possibilidade de medir, da escolha da "melhor métrica", da avaliação e da compatibilidade com outras medidas já existentes.

Nesse contexto, esta pesquisa busca avaliar a evolução da capacidade preditiva das informações contábeis em segregar as empresas entre grupos de Melhores e Piores alternativas de investimentos, a partir dos índices econômico-financeiros.

\subsection{ESTUDOS ANTERIORES SOBRE PREVISÕES DA SITUAÇÃO FINANCEIRA}

$\mathrm{Na}$ literatura contábil, diversas pesquisas têm considerado a utilização de índices econômico-financeiros para realizar previsões da situação financeira de empresas. Em razão da problemática da escolha e a diversidade de índices existentes na literatura, alguns estudiosos da área contábil têm evoluído na criação ou no agrupamento de índices que de alguma maneira contribuam para a mensuração do desempenho das empresas.

É o caso da pesquisa de Bortoluzzi et al. (2011), que, ao considerar os índices contábeis tradicionais, buscou integrá-los ao propor um modelo para avaliação de desempenho econômico-financeiro, com base nas percepções do decisor, com fins de possibilitar uma avaliação global do desempenho econômico-financeiro da organização. Nesse modelo, uma escala de zero ponto equivale a um nível "neutro" e 100 pontos equivale a um nível "bom", os resultados obtidos possibilitaram identificar um valor de desempenho econômico-financeiro global de 37 pontos em 2003 e de 16 pontos em 2005. A partir desse resultado, os autores acreditam que esse modelo pode auxiliar no processo de avaliação de desempenho.

A Análise fatorial é um método estatístico que contribui para diminuir o grau de subjetividade na escolha dos índices que deveriam compor a avaliação de empresas e 
permite uma avaliação simultânea de comportamento de diversos índices (BEZERRA; CORRAR, 2006).

Cita-se aqui, de forma breve, os estudos mais recentes de Bonfim et al. (2013), Bonfim et al. (2011) e Girioli (2010), que buscaram, através dessa técnica, explorar os índices financeiros e operacionais existentes na literatura contábil mais relevantes para se avaliar o desempenho de entidades. Os autores Bonfim et al. (2013) buscaram avaliar, por meio dessa metodologia, o desempenho das empresas do Setor de Petróleo e Gás a partir de 12 índices financeiros e operacionais levantados por meio bibliográfico. Os resultados revelaram a redução para três fatores: Rentabilidade, Alavancagem e Desempenho operacional. Estes estão relacionados à lucratividade das transações comerciais, à alavancagem financeira e operacional, à continuidade das operações e à capacidade de geração futura de valor das organizações pesquisadas.

Já a outra pesquisa desenvolvida por Bonfim et al. (2011) buscou identificar, entre 10 índices de rentabilidade, os quais deveriam ser considerados e sua relação na avaliação do desempenho das empresas do setor de Energia Elétrica, através da aplicação de análise fatorial e da análise de regressão, respectivamente. Os resultados revelaram um conjunto de três fatores distintos: Liquidez de curto prazo, Garantia operacional corrente e Necessidade de capital de giro. Com base nesses três fatores, pôde-se identificar apenas relação estatisticamente significativa do fator Garantia operacional com o retorno sobre o ativo e com o retorno sobre o patrimônio líquido.

Dentre essas pesquisas, destaca-se a pesquisa de Girioli (2010) que analisou as pesquisas da área contábil que estudaram medidas de desempenho de empresas a fim verificar quantas e quais são essas medidas e também identificar como elas poderiam ser agrupadas pela técnica de análise fatorial. A principal descoberta foi encontrar 237 variáveis diferentes na literatura contábil como Proxy da mensuração do desempenho. Contudo, observou-se que $62,44 \%$ dessas variáveis aparecem uma única vez no universo dos artigos, o que se deve a aplicações específicas de análise de desempenho, isto é, criadas para um contexto individual de cada pesquisa. Além disso, a análise fatorial revelou que as variáveis sempre vão se agrupar conforme os índices de análise das demonstrações e suas variáveis contábeis, concluindo que não é necessário usar diversas variáveis, pois os resultados apontaram que os índices mais frequentes e de maior explicação são aqueles extraídos das demonstrações contábeis.

Outra metodologia empregada nas pesquisas contábeis é a Análise Envoltória dos Dados, também conhecida como DEA (Data Envelopment Analysis), a qual é capaz 
de mensurar a eficiência financeira considerando os inputs de diversas variáveis de entrada para a produção de diversos outputs variáveis de saída. Em outras palavras, essa técnica tem a capacidade de abranger todas as variáveis envolvidas com as estratégias e planejamento, incluindo os parâmetros de desempenho da empresa (MELO et al., 2014).

Um exemplo da aplicação dessa metodologia nesse contexto é a pesquisa dos autores Brunozi Jr et al. (2012), que tem por objetivo determinar o grau de eficiência técnica e produtiva das usinas beneficiadoras de cana-de-açúcar do Estado de São Paulo, analisando concomitantemente seu desempenho econômico e financeiro. Para a mensuração, foram considerados 3 insumos (estoques, imobilizado e salários) e 1 produto (faturamento bruto). De um total de 17 empresas na amostra, os resultados encontrados mostraram que apenas 6 usinas analisadas se mostraram eficientes, apesar de 2 dessas empresas apresentarem problemas de escala, ao passo que as outras 11 foram consideradas ineficientes, sendo que 4 destas têm problema de escala (abaixo da escala ótima de produção) e sete são ineficientes tecnicamente por desperdiçarem insumos produtivos.

A técnica de Análise Hierárquica (AHP - Analytic Hierarchy Process) é outra metodologia destinada a problemas de decisão multicriterial, que requer que o decisor especifique sua preferência por cada alternativa usando cada critério e depois faça julgamentos acerca de sua importância relativa de cada critério. Essa metodologia foi utilizada pelos pesquisadores Macedo e Corrar (2010) com o objetivo de analisar o desempenho contábil-financeiro no setor brasileiro de seguradoras no ano de 2007. A análise de desempenho mostrou que a melhor seguradora foi a Mafra e o pior resultado foi da Sulina. Além disso, apesar de a variável de tamanho não ter relação com o desempenho, foi possível observar um impacto, ao nível de 5\% de significância, da variável tamanho no desempenho, pois o desempenho das cinco menores seguradoras se mostrou significativamente superior aos da cinco maiores.

Quanto as técnicas capazes de selecionar, relacionar e integrar os índices econômicos e financeiros mais relevantes, citam-se também as técnicas de Regressão Logística e de Análise Discriminante. Esta pesquisa pretende explorar mais esta última pelo fato de utilizar-se dessa metodologia para atingir os objetivos propostos.

Entretanto, vale ressaltar que ambas as metodologias possuem características semelhantes por buscarem discriminar a situação financeira de empresas com fins de elevar o poder de decisão dos gestores, investidores e demais públicos interessados em selecionar alternativas de investimentos. 
A pesquisa de Mota e Tavares (2015) avalia se a adoção das normas internacionais de contabilidade (IFRS) pelas empresas do segmento de energia elétrica com ações listadas na BM\&FBovespa proporcionou variação significativa na capacidade de segregar entre alternativas de investimento a partir da análise de índices econômico-financeiros. Para isso, a pesquisa selecionou 31 índices em uma regressão logística para estimar a classificação de cada caso e, em seguida, comparar com a classificação real, isto é, a segregação de empresas "vencedoras" e "perdedoras", utilizando o valor de mercado divulgado pela BM\&FBovespa. O nível de acertos da classificação realizada pela regressão logística foi significativamente melhor do que realizar tais previsões ao acaso. Entretanto, para validar esses resultados, foi aplicado o teste de igualdade de proporções populacionais, o qual apontou que não houve alteração significativa na capacidade preditiva da informação contábil no grupo de empresas analisado.

Já a pesquisa dos autores Artuso e Chaves Neto (2014) buscou aplicar as técnicas multivariadas de análise discriminante e regressão logística para o reconhecimento de padrões no mercado acionário brasileiro, isto é, reconhecer e classificar empresas que estejam possivelmente subavaliadas pelo mercado. Os resultados apresentados por essas duas técnicas indicaram um nível de acerto de $82 \%$ nos dois casos, e, a partir desses modelos, extraíram-se as seguintes variáveis, que são capazes de diferenciar significativamente as ações com retorno acima do mercado das demais: Preço do mercado, Taxa de dividendos e o Preço por valor contábil.

Semelhante à pesquisa acima, os autores Serra et al. (2014) buscaram verificar se existem características comuns das empresas que possam discriminar seus retornos em um dia de market crash, em dois grupos: o daquelas que perderam mais do que o mercado e o daquelas que perderam menos do que o mercado. A amostra compreende a análise das empresas listadas na NYSE no dia 15 de outubro de 2008, dia da maior queda do S\&P 500 dos últimos 23 anos (-9,0\%), através da regressão logística e da análise discriminante. Os resultados apontaram que as previsões de acertos atingiram $71,6 \%$ e $72,0 \%$ do modelo logit e discriminante, respectivamente. Ao passo que as variáveis com maior poder discriminante entre os grupos foram o retorno defasado de 2 meses e o desvio padrão de 1 ano.

Outra pesquisa que utilizou a técnica de análise discriminante foi a dos autores Teixeira et al. (2013), que buscaram estimar funções discriminantes para um grupo de empresas lucrativas, intermediárias e deficitárias listadas na BM\&FBovespa no período 
de 2009 a 2011. A partir das variáveis explicativas como os índices de liquidez, rentabilidade e estrutura de capital, os resultados indicaram a existência de separação entre os grupos, de modo que a variável com maior poder explicativo foi o índice de Composição do Endividamento.

Quanto à avaliação da previsão de insolvência a partir de índices econômicos e financeiros, citam-se as pesquisas dos autores HIJAZI et al. (2015) e Oro et al. (2012). Os primeiros buscaram evidenciar quais os índices que melhor explicam a falência das organizações pesquisadas, classificando-as em solventes e insolventes. Os autores testaram a realização da análise discriminante pelo método direto e stepwise, os quais obtiveram os seguintes níveis de acertos: $76,1 \%$ e $68,1 \%$, respectivamente. Ademais, as variáveis mais discriminantes que compuseram a função no método stepwise foram a relação do Lucro líquido sobre as vendas, Estoque médio sobre o custo das mercadorias vendidas e a soma do lucro operacional mais despesas sobre o ativo total menos investimento médio.

Já os autores Oro et al. (2012) buscaram identificar quais índices têm maior capacidade de predizer a probabilidade de dificuldades financeiras das empresas no setor têxtil, com o objetivo de classificar as empresas em dois grupos: empresas em recuperação judicial e empresas em atividades normais. Os índices que apresentaram maior valor preditivo para estimação da função discriminante foram: 3 índices de estrutura de capital (a relação do Exigível total em relação ao ativo e ao PL, e também do ativo fixo em relação ao PL), 2 de índices de rentabilidade (Margem líquida e ROA) e, por fim, 2 índices de Alavancagem (Financeira e Operacional). Além disso, a função discriminante obteve $100 \%$ do nível de acertos das classificações das empresas entre os dois grupos.

Outra técnica comumente utilizada na literatura contábil e financeira para auxiliar na tomada de decisões sobre investimentos é a Análise Financeira Fundamentalista-AFF, a qual foi abordada na tese de doutorado do Tavares (2010), que teve por objetivo avaliar se essa metodologia é capaz de prever variações do valor de mercado de empresas não-financeiras listadas na BM\&FBovespa nos anos de 2005, 2006 e 2007. O autor selecionou 23 índices econômico-financeiros para analisar a capacidade dessas variáveis em segregar as empresas entre dois grupos: Vencedoras e Perdedoras. Para tanto, o autor realizou a avaliação com a aplicação de três métodos de análise multivariada (Regra Qui-quadrado mínimo, Análise discriminante e o modelo Logit) a fim de verificar se os resultados de um método serão ratificados pelos demais. 
As classificações corretamente previstas nos três exercícios (71,2\%, 62\% e 62,5\%, respectivamente) indicam que o uso da AFF contribui para melhorar os resultados das decisões de investimentos. Adicionalmente, constatou-se grande similaridade ao se compararem os percentuais de acertos nas previsões dos três métodos.

Desse modo, observa-se que uma diversidade de técnicas se faz presente na literatura e é necessário observar as vantagens e desvantagens de cada uma delas na previsão da situação financeira de uma empresa a fim de se obter uma performance diferenciada em razão da especificidade, da dinamicidade, do tipo da amostra, da definição de desempenho e do número/complexidade das variáveis usadas no modelo.

Diante dessa breve apresentação de pesquisas acerca do tema, acredita-se que a qualidade da informação de uma análise econômica e financeira está intimamente ligada à escolha dos índices, pois a sua eficiência é verificada quando se permite avaliar o desempenho através da comparação entre os índices planejados e os observados, de modo que se verifique se a estratégia definida gerou os resultados esperados ou não. 


\section{METODOLOGIA}

A presente pesquisa parte do estudo de Tavares (2010), que recomenda a aplicação da metodologia utilizada em seu trabalho em empresas não financeiras do mercado brasileiro, após o processo de Convergência das Normas Internacionais de Contabilidade. A partir das informações contábeis, o autor obteve níveis de acertos entre $54 \%$ a $71 \%$, de acordo com o método estatístico utilizado, na capacidade de segregar as empresas entre melhores e piores alternativas de investimentos.

O presente trabalho segue a metodologia do estudo de Tavares (2010), adaptada aos exercícios pós-adoção dos IFRS pelas empresas participantes do segmento de Governança Corporativa da BM\&FBovespa, com exceção das empresas financeiras, e verifica os níveis de acertos durante o período de 2010 a 2014, a fim de testar se houve redução ou aumento da capacidade preditiva dos índices econômico-financeiros neste segmento que prioriza o disclosure como meio de proteção aos interesses dos stakeholders.

Para responder ao problema de pesquisa, desenvolveu-se um estudo com a abordagem metodológica empírico-analítica, cuja característica é utilizar-se de técnicas estatísticas para coleta, tratamento e análise dos dados, verificando-se, assim, a relação casual entre as variáveis investigadas (MARTINS; THEÓPHILO, 2009).

\subsection{SELEÇÃO DOS ÍNDICES E COLETA DE DADOS}

Inicialmente, para a realização deste estudo, foram consultados os principais meios de divulgação da pesquisa Contábil no Brasil, no período de 2010 a 2014, a fim de levantar e selecionar os índices econômico-financeiros mais utilizados para avaliar o desempenho das empresas.

Este estudo deteve-se a analisar os artigos científicos nacionais publicados em 26 Periódicos com o estrato A2, B1 e B2 pela qualis/Capes na área Administração, Ciências Contábeis e Turismo, conforme Quadro 1. Ressalta-se que, por não haver periódicos nacionais, não foi incluído o estrato A1 nesta pesquisa. 
Quadro 1 - Periódicos Consultados

\begin{tabular}{|c|c|c|}
\hline REVISTAS & ISSN & ESTRATO \\
\hline BAR. Brazilian Administration Review & $1807-7692$ & $\mathrm{~A} 2$ \\
\hline BBR. Brazilian Business Review & $1807-734 \mathrm{X}$ & $\mathrm{A} 2$ \\
\hline Gestão \& Produção & 1806-9649 ou 0104-530X & $\mathrm{A} 2$ \\
\hline RAC Eletrônica & $1981-5700$ & $\mathrm{~A} 2$ \\
\hline RAC - Revista de Administração Contemporânea & $1415-6555$ ou $1982-7849$ & A2 \\
\hline RAE Eletrônica & $1676-5648$ & $\mathrm{~A} 2$ \\
\hline RAE - Revista de Administração de Empresas & $0034-7590$ ou $2178-938 x$ & A2 \\
\hline RAUSP-e & $1983-7488$ & $\mathrm{~A} 2$ \\
\hline Revista Contabilidade \& Finanças & $1519-7077$ ou $1808-057 X$ & A2 \\
\hline Revista Brasileira de Economia & $0034-7140$ & A2 \\
\hline Revista de Administração & 0080-2107 ou 1984-6142 & A2 \\
\hline Revista de Administração Pública & 0034-7612 & $\mathrm{A} 2$ \\
\hline Revista Base & $1984-8196$ ou $1807-054 X$ & $\mathrm{~B} 1$ \\
\hline Cadernos EBAPE.BR & $1679-3951$ & $\mathrm{~B} 1$ \\
\hline Contabilidade Vista \& Revista & $0103-734 X$ & $\mathrm{~B} 1$ \\
\hline Custos e @gronegócio Online & $1808-2882$ & B1 \\
\hline Revista Brasileira de Finanças & $1679-0731$ ou $1984-5146$ & $\mathrm{~B} 1$ \\
\hline Revista Contemporânea de Contabilidade & $2175-8069$ ou $1807-1821$ & $\mathrm{~B} 1$ \\
\hline Revista de Contabilidade e Organizações & $1982-6486$ & $\mathrm{~B} 1$ \\
\hline Revista Universo Contábil & $1809-3337$ & B1 \\
\hline Advances in Scientific and Applied Accounting & $1983-8611$ & $\mathrm{~B} 2$ \\
\hline Contabilidade, Gestão e Governança & $1984-3925$ & $\mathrm{~B} 2$ \\
\hline Enfoque: Reflexão Contábil & $1517-9087$ & $\mathrm{~B} 2$ \\
\hline $\begin{array}{l}\text { RACE: Revista de Administração, Contabilidade e } \\
\text { Economia }\end{array}$ & $1678-6483$ ou $2179-4936$ & $\mathrm{~B} 2$ \\
\hline Revista Ambiente Contábil & $2176-9036$ & $\mathrm{~B} 2$ \\
\hline Revista de Educação e Pesquisa em Contabilidade & $1981-8610$ & $\mathrm{~B} 2$ \\
\hline
\end{tabular}

Fonte: Elaborada pela autora.

Nesta primeira etapa, foram selecionados 73 artigos que mensuravam o desempenho das empresas a partir de índices econômico-financeiros para que deles fossem extraídas as variáveis utilizadas em cada estudo, conforme lista de artigos no apêndice "A". Dessa forma, esta pesquisa mapeou e selecionou as variáveis econômicofinanceiras que apresentaram frequência acima de 7 para serem utilizadas como variáveis independentes neste estudo, conforme estão relacionados na Quadro 2.

Salienta-se que não existe uma explicação científica para a escolha da frequência acima de 7, apenas observou-se que os 14 índices econômico-financeiros selecionados a partir dessa forma provavelmente estariam presentes em pelo menos $10 \%$ de todos os artigos pesquisados. 
Quadro 2 - Índices selecionados nesta pesquisa

\begin{tabular}{|c|c|c|}
\hline Índice & Fórmula & Frequência \\
\hline ROA & $\frac{\text { LucroLiquido }}{\text { Ativo }}$ & 44 \\
\hline ROE & $\frac{\text { Lucro Líquido }}{\text { Patrimônio Líquido }}$ & 37 \\
\hline Margem Líquida & $\frac{\text { Lucro Líquido }}{\text { Venda Líquida }}$ & 20 \\
\hline Grau de Endividamento & $\frac{\text { Passivo }+ \text { Patrimônio Líquido }}{\text { Ativos }}$ & 16 \\
\hline Giro do Ativo & $\frac{\text { Vendas }}{\text { Ativos }}$ & 14 \\
\hline Liquidez Corrente & $\frac{\text { Ativo Circulante }}{\text { Passivo Circulante }}$ & 12 \\
\hline Q de Tobin & $\frac{\text { Valor de Mercado }+ \text { Dívidas Totais }}{\text { Ativo Total }}$ & 12 \\
\hline Liquidez Geral & $\frac{\text { Ativo Circulante }+ \text { Realizável a Longo Prazo }}{\text { Passivo Circulante }+ \text { Passivo Não Circulante }}$ & 11 \\
\hline Endividamento Geral & $\frac{\text { Passivo Circulante + Passivo Não Circulante }}{\text { Patrimônio Líquido }}$ & 11 \\
\hline Crescimento das Vendas & $\frac{\text { Vendas }^{T}}{\operatorname{Vendas}^{T-1}}$ & 10 \\
\hline Book-to-market & $\frac{\text { Valor das ações no mercado }}{\text { Valor da ação contábil }}$ & 9 \\
\hline Margem Operacional & $\frac{\text { Lucro Operacional }}{\text { Receita }}$ & 9 \\
\hline Margem Ebtida & $\frac{\text { Ebtida }}{\text { Vendas Líquidas }}$ & 8 \\
\hline PCCT & $\frac{\text { Passivo Circulante }}{\text { Passivo }}$ & 8 \\
\hline
\end{tabular}

Fonte: Elaborada pela autora.

A segunda etapa desta pesquisa foi coletar os valores desses índices econômicofinanceiros para cada empresa presente na amostra através do banco de dados Bloomberg $^{\circledR}$, no período de 2010 a 2014.

Em razão do grande número de variáveis presentes neste estudo, optou-se em associar um código no formato $\mathrm{X}_{\mathrm{i}}$, onde "i" pode assumir os valores de 1 a 14, para que se possa identificar e evitar a repetição do nome da variável que estiver sendo utilizada, conforme mostra a Quadro 3 a seguir. Além disso, de forma breve e não exaustiva, expõem-se ao lado da coluna dos índices seus respectivos significados. 
Quadro 3 - Códigos Identificadores dos índices econômico-financeiros

\begin{tabular}{|c|c|c|}
\hline Código & Índice & Definição \\
\hline $\mathrm{X}_{1}$ & ROA & $\begin{array}{l}\text { É um índice de rentabilidade que busca medir a eficiência } \\
\text { dos ativos na produção dos lucros (REIS et al., 2013) }\end{array}$ \\
\hline $\mathrm{X}_{2}$ & ROE & $\begin{array}{l}\text { Índice de rentabilidade que mede o retorno do capital } \\
\text { investido pelos proprietários (ALVES et al., 2013) }\end{array}$ \\
\hline$X_{3}$ & Margem Líquida & $\begin{array}{l}\text { Permite avaliar o nível de rentabilidade com suas receitas } \\
\text { operacionais líquidas (GONÇALVES et al., 2012) }\end{array}$ \\
\hline $\mathrm{X}_{4}$ & Grau de Endividamento & $\begin{array}{c}\text { Mede o endividamento ou alavancagem financeira da } \\
\text { empresa (FORTI et al., 2011) }\end{array}$ \\
\hline $\mathrm{X}_{5}$ & Giro do Ativo & $\begin{array}{l}\text { Verifica o nível de eficiência com que são utilizados os } \\
\text { recursos empregados a partir da relação entre as vendas e os } \\
\text { investimentos totais realizados (BONFIM et al., 2013) }\end{array}$ \\
\hline $\mathrm{X}_{6}$ & Liquidez Corrente & $\begin{array}{l}\text { Indica o quanto existe de ativo circulante para cada } \mathrm{R} \$ 1 \text { de } \\
\text { dívida a curto prazo (REZENDE et al., 2010) }\end{array}$ \\
\hline $\mathrm{X}_{7}$ & Q de Tobin & $\begin{array}{c}\text { Indica a performance obtida pelas ações da empresa no } \\
\text { mercado acionário relacionada ao seu ativo total } \\
\text { (NAVARRO et al., 2013) }\end{array}$ \\
\hline $\mathrm{X}_{8}$ & Liquidez Geral & $\begin{array}{c}\text { Revela a capacidade que a empresa dispõe para saldar todas } \\
\text { as suas dívidas (REZENDE et al., 2010) }\end{array}$ \\
\hline $\mathrm{X}_{9}$ & Endividamento Geral & $\begin{array}{l}\text { Indica quanto uma empresa tomou de capital de terceiros em } \\
\text { relação aos recursos de capital próprio (GUTH et al., 2011) }\end{array}$ \\
\hline $\mathrm{X}_{10}$ & Crescimento das Vendas & $\begin{array}{l}\text { Mede o efeito de crescimento a partir das vendas do período } \\
\text { adicionado da taxa de crescimento para o período (BRITO; } \\
\text { BRITO, 2014) }\end{array}$ \\
\hline $\mathrm{X}_{11}$ & Book-to-market & $\begin{array}{l}\text { Relaciona o valor de mercado das ações dividido pelo valor } \\
\text { patrimonial das ações (NAVARRO et al., 2013) }\end{array}$ \\
\hline $\mathrm{X}_{12}$ & Margem Operacional & $\begin{array}{l}\text { Informa o retorno da atividade-fim da empresa em relação ao } \\
\text { faturamento líquido da empresa (BONFIM et al., 2013) }\end{array}$ \\
\hline $\mathrm{X}_{13}$ & Margem Ebtida & $\begin{array}{l}\text { Mede o percentual do potencial de geração de caixa que a } \\
\text { empresa produz para cada unidade de vendas (RIBEIRO et } \\
\text { al., 2012) }\end{array}$ \\
\hline $\mathrm{X}_{14}$ & PCCT & $\begin{array}{c}\text { Mede o percentual de obrigações de curto prazo em relação } \\
\text { às obrigações totais (RIBEIRO et al., 2012) }\end{array}$ \\
\hline
\end{tabular}

Fonte: Elaborada pela autora.

No tratamento estatístico dos dados, buscar-se-ão associar a cada empresa todos os índices de desempenho econômico-financeiro definidos acima. Assim, a uma empresa Fulana S.A., por exemplo, estarão associados os valores dos índices de $\mathrm{X}_{1}$ a $\mathrm{X}_{14}$. 


\subsection{POPULAÇÃO E AMOSTRA}

A população desta pesquisa compreende as companhias listadas nos Níveis Diferenciados de Governança (Novo Mercado, Nível 1 e Nível 2) da BM\&FBovespa, no período de 2010 a 2014.

Para constar na amostra, primeiramente foram selecionadas apenas as empresas que se mantiveram constantes nos níveis de Governança Corporativa nesse período. Segundo, foi verificado se o valor de mercado de cada empresa estava disponível no banco de dados no último dia útil do ano anterior, bem como no último dia útil de cada exercício social em análise, de 2010 a 2014.

Esses requisitos tiveram, por fim, a análise das variações percentuais positivas ou negativas nos valores de mercado das empresas em cada exercício social em estudo, para a formação de um ranking de vencedoras/perdedoras (vide Apêndice B).

Outro requisito foi a exclusão de todas as empresas que apresentassem o valor do Patrimônio Líquido negativo durante o estudo, uma vez que tal situação patrimonial prejudicaria a interpretação dos resultados e análise dos índices econômico-financeiros que têm por denominador o valor do PL.

Após esse tratamento, chegou-se à relação, listada no Quadro 4, das 98 empresas que integraram a amostra deste estudo.

Quadro 4 - Empresas participantes deste estudo

\begin{tabular}{|c|c|c|c|}
\hline $\mathbf{N}^{\mathbf{0}}$ & Empresas & $\mathbf{N}^{\mathbf{o}}$ & Empresas \\
\hline 1 & All America Latina Logística S.A. & 17 & Cia Paranaense De Energia - Copel \\
\hline 2 & Alpargatas S.A. & 18 & Cia Providencia Industria E Comercio \\
\hline 3 & Arteris S.A. & 19 & Cia Saneamento Basico Est São Paulo \\
\hline 4 & B2w - Companhia Digital & 20 & Cia Saneamento De Minas Gerais-Copasa Mg \\
\hline 5 & Bematech S.A. & 21 & Cosan S.A. Industria E Comercio \\
\hline 6 & Bhg Sa - Brazil Hospitality Group & 22 & Cpfl Energia S.A. \\
\hline 7 & Brasil Brokers Participações S.A. & 23 & Cr2 Empreendimentos Imobiliarios S.A. \\
\hline 8 & Braskem S.A. & 24 & Csu Cardsystem S.A. \\
\hline 9 & Brf S.A. & 25 & Cteep - Cia Transmissão Energia Elétrica Paulista \\
\hline 10 & Ccr S.A. & 26 & Cyrela Brazil Realty S.A.Empreend E Part \\
\hline 11 & Centrais Elet.de Santa Catarina S.A. & 27 & Diagnosticos Da America S.A. \\
\hline 12 & Centrais Elet. Bras. S.A. - Eletrobras & 28 & Direcional Engenharia S.A. \\
\hline 13 & Cesp - Cia Energética de São Paulo & 29 & Duratex S.A. \\
\hline 14 & Cia Brasileira de Distribuição & 30 & Edp - Energias Do Brasil S.A. \\
\hline 15 & Cia Energética de Minas Gerais - Cemig & 31 & Eletropaulo Metrop. Elet. São Paulo S.A. \\
\hline 16 & Cia Hering & 32 & Embraer S.A. \\
\hline
\end{tabular}


(Conclui)

\begin{tabular}{|c|c|c|c|}
\hline $\mathbf{N}^{\mathbf{o}}$ & Empresas & $\mathbf{N}^{\mathbf{o}}$ & Empresas \\
\hline 33 & Equatorial Energia S.A. & 66 & Metalurgica Gerdau S.A. \\
\hline 34 & Estacio Participacoes S.A. & 67 & Minerva S.A. \\
\hline 35 & Eternit S.A. & 68 & Mrv Engenharia E Participacoes S.A. \\
\hline 36 & Eucatex S.A. Industria E Comercio & 69 & Natura Cosmeticos S.A. \\
\hline 37 & $\begin{array}{l}\text { Even Construtora E Incorporadora } \\
\text { S.A. }\end{array}$ & 70 & Odontoprev S.A. \\
\hline 38 & $\begin{array}{l}\text { Ez Tec Empreend. E Participacoes } \\
\text { S.A. }\end{array}$ & 71 & Paranapanema S.A. \\
\hline 39 & Fertilizantes Heringer S.A. & 72 & Pdg Realty S.A. Empreend E Participacoes \\
\hline 40 & Fibria Celulose S.A. & 73 & Portobello S.A. \\
\hline 41 & Fleury S.A. & 74 & Positivo Informatica S.A. \\
\hline 42 & Fras-Le S.A. & 75 & Profarma Distrib Prod Farmaceuticos S.A. \\
\hline 43 & Gafisa S.A. & 76 & Prumo Logística S.A. \\
\hline 44 & Gerdau S.A. & 77 & Raia Drogasil S.A. \\
\hline 45 & Grendene S.A. & 78 & Randon S.A. Implementos E Participacoes \\
\hline 46 & Helbor Empreendimentos S.A. & 79 & Rodobens Negocios Imobiliarios S.A. \\
\hline 47 & Hypermarcas S.A. & 80 & Rossi Residencial S.A. \\
\hline 48 & Ideiasnet S.A. & 81 & Santos Brasil Participacoes S.A. \\
\hline 49 & Industrias Romi S.A. & 82 & Sao Martinho S.A. \\
\hline 50 & Iochpe Maxion S.A. & 83 & Saraiva S.A. Livreiros Editores \\
\hline 51 & Jbs S.A. & 84 & Slc Agricola S.A. \\
\hline 52 & Jhsf Participacoes S.A. & 85 & Suzano Papel E Celulose S.A. \\
\hline 53 & Klabin S.A. & 86 & Tecnisa S.A. \\
\hline 54 & Kroton Educacional S.A. & 87 & Tegma Gestao Logistica S.A. \\
\hline 55 & Light S.A. & 88 & Tempo Participacoes S.A. \\
\hline 56 & Localiza Rent A Car S.A. & 89 & Terios Internacional S.A. \\
\hline 57 & Log-In Logistica Intermodal S.A. & 90 & Totvs S.A. \\
\hline 58 & Lojas Renner S.A. & 91 & Tpi - Triunfo Particip. E Invest. S.A. \\
\hline 59 & $\begin{array}{l}\text { Lps Brasil - Consultoria De Imoveis } \\
\text { S.A. }\end{array}$ & 92 & Tractebel Energia S.A. \\
\hline 60 & $\begin{array}{l}\text { M.Dias Branco S.A. Ind Com De } \\
\text { Alimentos }\end{array}$ & 93 & Trisul S.A. \\
\hline 61 & Magnesita Refratarios S.A. & 94 & Usinas Sid De Minas Gerais S.A.-Usiminas \\
\hline 62 & Marcopolo S.A. & 95 & Vale S.A \\
\hline 63 & Marfrig Global Foods S.A. & 96 & Valid Soluções E Serv. Seg. Meios Pag. Ident. S.A. \\
\hline 64 & Marisa Lojas S.A. & 97 & Vanguarda Agro S.A. \\
\hline 65 & Metalfrio Solutions S.A. & 98 & Weg S.A \\
\hline
\end{tabular}

Fonte: Elaborada pela autora.

Em cada exercício social, essas empresas foram classificadas em ordem decrescente de geração de valor, tendo por referencial as variações relativas de valor de mercado, de modo que se possam identificar as empresas "Vencedoras", que apresentaram maior agregação de valor (primeiro terço, 33,33\% dessa amostra), bem 
como as "Perdedoras", que apresentaram menor agregação de valor (terceiro terço, $33,33 \%)$.

A amostra final para análise corresponde a 2/3 da amostra disponível (66 empresas) e, desse modo, selecionaram-se as empresas mais afastadas da mediana da população, e com perfis mais bem definidos, a fim de melhorar a segregação das empresas em grupos de melhores e piores alternativas de investimento.

\subsection{TRATAMENTO DOS DADOS}

\subsubsection{Observações Atípicas (OUTLIERS)}

As Observações Atípicas, segundo Hair Jr et al. (2005), são observações com uma combinação única de características identificáveis como sendo notavelmente diferentes das outras observações. Os métodos usados para detectar observações atípicas são: detecção univariada, detecção bivariada e detecção multivariada.

Uma vez que esta pesquisa utilizará uma técnica multivariada para tratamento dos dados, utilizar-se-á, então, o método de detecção multivariada proposto por Hair Jr et al. (2005), a medida $D^{2}$ de Mahalanobis. Essa técnica mede a distância, em um espaço multidimensional, de cada observação em relação ao centro médio das observações (HAIR Jr et al., 2005).

A $D^{2}$ de Mahalanobis pode ser calculada a partir da fórmula a seguir:

$$
D^{2}=\left(x_{i}-\mu\right)^{\prime} \Sigma^{-1}\left(x_{i}-\mu\right)
$$

Onde:

$x=$ vetor multivariado de observações de uma empresa.

$\mu=$ média das variáveis independentes da amostra.

$\Sigma^{-1}=$ inversa da matriz de variâncias-covariâncias da amostra.

Segundo Hair Jr et al. (2005), na avaliação dos resultados a partir da técnica $\mathrm{D}^{2}$ de Mahalanobis, sugere-se utilizar um nível muito conservador, como 0,001, que servirá de valor base para identificar uma observação atípica. Desse modo, a Tabela 1 abaixo evidencia o número de empresas que apresentaram alguma observação atípica no estudo e o número final de empresas presentes na amostra. 
Tabela 1 - Impacto dos Outliers nas amostras anuais

\begin{tabular}{c|c|c|c}
\hline Exercício Social & $\mathbf{N}^{\mathbf{o}}$ de empresas & $\begin{array}{c}\text { Empresas Afetadas por } \\
\text { Outliers }\end{array}$ & Amostra final \\
\hline 2010 & 66 & 3 & 63 \\
\hline 2011 & 66 & 4 & 62 \\
\hline 2012 & 66 & 5 & 61 \\
\hline 2013 & 66 & 5 & 61 \\
\hline 2014 & 66 & 5 & 61 \\
\hline
\end{tabular}

Fonte: Dados da pesquisa.

\subsubsection{Segregação das Amostras}

Dando continuidade ao processo de tratamento da amostra, Hair Jr et al. (2005) recomendam que, para a aplicação do teste de análise discriminante, a amostra total de respondentes seja dividida em dois grupos. Um deles será a amostra de análise, a qual será utilizada para desenvolver a função, o outro grupo será a amostra de teste, em que a amostra será usada para testar a função discriminante.

Em outras palavras, os autores Hair Jr et al. (2005) explicam que a divisão da amostra inicial em duas subamostras tem por objetivo usar uma delas para obtenção da função discriminante e análise das relações entre as variáveis preditoras (índices) e o problema de classificação. A outra subamostra tem por fim a avaliação final da capacidade classificatória da função discriminante, com novos elementos que não foram utilizados para o seu desenvolvimento. Esse método de validação é conhecido como validação cruzada.

Ademais, este autor acrescenta que não há qualquer determinação acerca do tamanho de cada subamostra, sendo comuns divisões nas proporções do tipo 50-50, 6040 ou mesmo 75-25 para a amostra de análise e de teste. Contudo deve-se seguir um procedimento de estratificação que, no final, obtenha o tamanho de cada categoria integrante da subamostra de, no mínimo, 20 casos, a fim de proporcionar maior robustez às análises.

Esta pesquisa utilizar-se-á do critério de estratificação da amostra final nas proporções do tipo 50-50 entre análise e teste, e ressalta-se também que as subamostras de análise e de teste seguirão essa mesma proporção para discriminar as empresas em Melhores e Piores. A Tabela 2 a seguir evidencia a segregação das amostras anuais. 
Tabela 2 - Segregação das amostras anuais

\begin{tabular}{c|c|c|c}
\hline Exercício & Amostra & Subamostra de Análise & Subamostra de Teste \\
\hline 2010 & 63 & 31 & 32 \\
\hline 2011 & 62 & 31 & 31 \\
\hline 2012 & 61 & 31 & 30 \\
\hline 2013 & 61 & 31 & 30 \\
\hline 2014 & 61 & 30 & 31 \\
\hline
\end{tabular}

Fonte: Dados da pesquisa.

Assim, concretizam-se os últimos ajustes necessários às amostras coletadas, e a próxima fase será a realização do teste econométrico dos dados, isto é, a Análise Discriminante com fins de atingir os objetivos da pesquisa.

\subsubsection{Análise Discriminante}

A análise discriminante é um método que pode ser utilizado para classificar os elementos de uma amostra ou população, desde que os grupos para os quais cada elemento amostral pode ser classificado sejam conhecidos a priori considerando-se suas características gerais (MINGOTI, 2013).

Sua principal característica é a utilização de um conjunto de informações obtidas acerca de variáveis consideradas independentes para conseguir um valor de uma variável dependente que possibilite a classificação desejada (MARIO, 2009).

Segundo Mario (2009), na análise discriminante, a variável dependente é de natureza qualitativa (não métrica), pois seu valor representará uma classificação estabelecida (bom ou mau, melhor ou pior etc.), ao passo que as variáveis independentes são métricas com valores contínuos (como os índices financeiros). A partir desse conhecimento, é possível elaborar uma função matemática chamada de regra de classificação ou discriminação, que será utilizada para classificar novos elementos amostrais nos grupos já existentes (MINGOTI, 2013)

Essa função é composta pelas variáveis independentes que representam as características do elemento, as quais serão ponderadas pelo nível de sua importância ou impacto que causam no resultado ou variável dependente, a qual assume a seguinte forma (MARIO, 2009):

$$
Z=a+b_{1} X_{1}+b_{2} X_{2}+\cdots++b_{n} X_{n}
$$


Onde:

$Z=$ é a variável dependente categórica, que indica uma pontuação ou escore discriminante;

$a=$ é o intercepto da função quando todo $\mathrm{X}_{\mathrm{i}}=0$;

$b_{\mathrm{n}}=$ é o coeficiente discriminante ou a capacidade que cada variável independente tem em discriminar (o peso de cada uma na função);

$X_{\mathrm{n}}=$ são os valores das variáveis independentes.

A principal aplicação da análise discriminante são as classificações dicotômicas (dois grupos), em que, para atender os objetivos da questão desta pesquisa, requer a discriminação dos componentes da amostra em dois grupos: Empresas Melhores e Empresas Piores a partir da análise das variáveis independentes (índices econômicofinanceiros). Assim, acredita-se que a aplicação da técnica de análise discriminante simples constitui um tratamento estatístico adequado à solução do problema de pesquisa.

Conforme Mario (2009), alguns passos devem ser observados para a construção de uma função discriminante:

1. Identificar o problema e classificar os elementos em grupos;

2. Selecionar as variáveis independentes, avaliar o tamanho da amostra e segregá-la em duas amostras: de análise e de teste;

3. Testar as premissas para $\mathrm{AD}$;

4. Estimar os coeficientes da função discriminante e avaliar a significância estatística da função e seu grau de acurácia;

5. Interpretar o resultado da função discriminante e sua validade.

Após encontrar-se a equação discriminante, esta será aplicada sobre os dados da amostra de análise para obter o valor da variável dependente $\mathrm{Z}$ (escore discriminante). Então, calcula-se a média dos Zs (escores) de cada grupo para servir de base para o cálculo do ponto de corte ou escore crítico e, finalmente, o valor médio entre as médias dos grupos para discriminar a qual grupo pertence a nova empresa (MARIO, 2009; HAIR Jr et al., 2005).

Como o tamanho da subamostra do teste é diferente da subamostra usada para construir o modelo, conforme mostra a Tabela 6, utilizar-se-á a fórmula a seguir para 
ponderar os centroides em razão do número de empresas de cada grupo para todos os anos desta pesquisa (HAIR Jr et al., 2005):

$$
Z_{E C}=\frac{n_{1} Z_{2}+n_{2} Z_{1}}{n_{1}+n_{2}}
$$

Onde:

$\mathrm{Z}_{\mathrm{EC}}=$ escore crítico para $n$ diferente;

$\mathrm{n}_{1}=$ número de observações do grupo 1 ;

$\mathrm{n}_{2}=$ número de observações do grupo 2 ;

$\mathrm{Z}_{1}=$ ponto centroide do grupo 1 ;

$\mathrm{Z}_{2}=$ ponto centroide do grupo 2 .

Por fim, o autor Mario (2009) ressalta que, para o uso da análise discriminante, faz-se necessária a observação das seguintes premissas para conferir maior robustez aos resultados:

a) Normalidade Multivariada: esse pressuposto indica que a combinação linear entre as variáveis das funções deve ter uma distribuição normal, a qual será testada em um nível de significância de 0,05 a partir da estatística Kolmogorov-Smirnov aos resíduos da função discriminante de cada exercício social;

b) Linearidade: verificada a partir da combinação linear entre as variáveis independentes e a variável dependente na função discriminante;

c) Ausência de outliers: verifica-se a partir da técnica de detecção multivariada através do teste $D_{2}$ de Mahalanobis, conforme tópico 5.3.1 - Observações Atípicas (outliers);

d) Ausência de multicolinearidade: ocorre quando existe redundância entre as variáveis preditoras, em que será analisada a partir da medida de Tolerância e Fator de Inflação da Variância (VIF);

e) Homogeneidade das matrizes de variância-covariância: tem o objetivo de evitar que a função discriminante classifique observações em grupos de maior variância, isto é, evitar que haja erro no ponto de corte, e será analisada a partir do Teste Box's $M$, cujo objetivo é que as covariâncias das categorias nas amostras sejam iguais. 
A realização de todos os procedimentos para a estatística Análise Discriminante será realizada com a utilização do software Statistical Package for the Social Sciences SPSS® (Versão 21). 


\section{ANÁLISE DOS RESULTADOS}

\subsection{PREMISSAS DA ESTATÍSTICA DA ANÁLISE DISCRIMINANTE}

Conforme detalhado no tópico anterior (5.3.3 Análise Discriminante), a Análise Discriminante requer a aplicação dos seguintes testes como pressupostos para que se obtenha maior robustez nos resultados dessa metodologia:

\section{a) Normalidade multivariada}

Para realizar o teste da Normalidade Multivariada, foi utilizado o teste Kolmogorov-Smirnov, em um nível de 0,05 de significância, aplicado à subamostra de análise decorrente da Análise Discriminante em cada exercício social. Esse teste pressupõe que os dados são normalmente distribuídos.

Tabela 3 - Resultados do Teste Kolmogorov-Smirnov nas amostras de análise

\begin{tabular}{|c|c|c|c|c|c|c|c|c|c|c|c|c|c|c|c|}
\hline & & $\mathbf{X}_{1}$ & $\mathbf{X}_{2}$ & $\mathbf{X}_{3}$ & $\mathbf{X}_{4}$ & $\mathbf{X}_{5}$ & $\mathbf{X}_{6}$ & $\mathbf{X}_{\mathbf{7}}$ & $\mathbf{X}_{\mathbf{8}}$ & $\mathbf{X}_{9}$ & $X_{10}$ & $X_{11}$ & $X_{12}$ & $X_{13}$ & $X_{14}$ \\
\hline \multirow{3}{*}{2010} & $\mathrm{~N}$ & 31 & 31 & 31 & 31 & 31 & 31 & 31 & 31 & 31 & 31 & 31 & 31 & 31 & 31 \\
\hline & $\begin{array}{c}\text { Kolmogorov- } \\
\text { Smirnov Z }\end{array}$ & 0,61 & 1,14 & 0,53 & 1,51 & 0,70 & 1,35 & 1,62 & 1,80 & 2,63 & 1,20 & 0,71 & 1,05 & 1,64 & 1,94 \\
\hline & $\begin{array}{l}\text { Sig. Assint. } \\
\text { (2 caudas) }\end{array}$ & 0,85 & 0,15 & 0,94 & 0,02 & 0,71 & 0,05 & 0,01 & 0,00 & 0,00 & 0,11 & 0,70 & 0,22 & 0,01 & 0,00 \\
\hline \multirow{3}{*}{2011} & $\mathrm{~N}$ & 31 & 31 & 31 & 31 & 31 & 31 & 31 & 31 & 31 & 31 & 31 & 31 & 31 & 31 \\
\hline & $\begin{array}{c}\text { Kolmogorov- } \\
\text { Smirnov Z }\end{array}$ & 0,87 & 0,98 & 0,47 & 0,76 & 1,10 & 1,06 & 2,21 & 0,40 & 2,75 & 0,57 & 0,83 & 0,73 & 1,43 & 2,17 \\
\hline & $\begin{array}{l}\text { Sig. Assint. } \\
\text { (2 caudas) }\end{array}$ & 0,44 & 0,29 & 0,98 & 0,61 & 0,18 & 0,21 & 0,00 & 1,00 & 0,00 & 0,91 & 0,50 & 0,67 & 0,03 & 0,00 \\
\hline \multirow{3}{*}{2012} & $\mathrm{~N}$ & 31 & 31 & 31 & 31 & 31 & 31 & 31 & 31 & 31 & 31 & 31 & 31 & 31 & 31 \\
\hline & $\begin{array}{c}\text { Kolmogorov- } \\
\text { Smirnov Z } \\
\end{array}$ & 0,57 & 1,18 & 0,48 & 1,32 & 0,58 & 1,40 & 1,14 & 1,06 & 1,28 & 0,63 & 1,61 & 0,74 & 1,23 & 1,54 \\
\hline & $\begin{array}{l}\text { Sig. Assint. } \\
\text { (2 caudas) }\end{array}$ & 0,91 & 0,13 & 0,98 & 0,06 & 0,89 & 0,04 & 0,15 & 0,21 & 0,08 & 0,82 & 0,01 & 0,64 & 0,10 & 0,02 \\
\hline \multirow{3}{*}{2013} & $\mathrm{~N}$ & 31 & 31 & 31 & 31 & 31 & 31 & 31 & 31 & 31 & 31 & 31 & 31 & 31 & 31 \\
\hline & $\begin{array}{c}\text { Kolmogorov- } \\
\text { Smirnov Z }\end{array}$ & 0,92 & 0,61 & 1,10 & 1,28 & 1,19 & 1,03 & 0,92 & 1,26 & 0,84 & 1,31 & 1,98 & 0,53 & 1,20 & 1,38 \\
\hline & $\begin{array}{l}\text { Sig. Assint. } \\
(2 \text { caudas })\end{array}$ & 0,37 & 0,85 & 0,17 & 0,08 & 0,12 & 0,24 & 0,37 & 0,08 & 0,48 & 0,07 & 0,00 & 0,94 & 0,11 & 0,04 \\
\hline \multirow{3}{*}{2014} & $\mathrm{~N}$ & 30 & 30 & 30 & 30 & 30 & 30 & 30 & 30 & 30 & 30 & 30 & 30 & 30 & 30 \\
\hline & $\begin{array}{c}\text { Kolmogorov- } \\
\text { Smirnov Z }\end{array}$ & 0,65 & 0,53 & 1,10 & 1,37 & 0,62 & 1,45 & 0,87 & 1,50 & 0,64 & 1,03 & 1,62 & 0,68 & 0,77 & 0,71 \\
\hline & $\begin{array}{l}\text { Sig. Assint. } \\
\text { (2 caudas) }\end{array}$ & 0,79 & 0,94 & 0,18 & 0,05 & 0,84 & 0,03 & 0,44 & 0,02 & 0,80 & 0,24 & 0,01 & 0,74 & 0,59 & 0,70 \\
\hline
\end{tabular}

Fonte: Dados da pesquisa realizados no SPSS (2016). 
A partir da Tabela 3, percebe-se que mais de 60\% das variáveis apresentaram significância maior que 0,05 no período de 2010 a 2014. Logo, não se pode rejeitar a hipótese principal de distribuição normal.

Por outro lado, apesar de algumas variáveis apresentarem sig menor que 0,05 (conforme destaque na tabela), isto é, não apresentarem distribuição normal, optou-se em executar a análise discriminante com todas as variáveis para verificar os resultados obtidos.

\section{b) Linearidade}

Segundo HAIR Jr et al. (2005), a Linearidade é um pressuposto implícito em todas as técnicas de análise multivariadas que se baseiam em medidas correlacionais de associação.

Esse autor acrescenta que os modelos lineares preveem valores que recaem em uma linha reta e que representam o resultado da relação entre a variável dependente e as independentes, a qual pode ser matematicamente escrita como: $y=b_{0}+b_{1} x_{1}+E$.

Nesse quesito, as variáveis dependentes e independentes se assemelham às da pesquisa realizada por Tavares (2010) por não apresentarem formato exponencial, ou de qualquer outro tipo que prejudique a relação linear da função. Assim, esta pesquisa atende ao pressuposto da Linearidade.

\section{c) Ausência de Outliers}

Segundo Mário (2009), a presença de outliers prejudica fortemente a Análise Discriminante. Dessa forma, devem-se realizar os testes pra identificar, transformar e, se for o caso, eliminar da amostra os outliers antes da aplicação da Análise Discriminante.

Conforme descrito no tópico 5.3.1 Observações Atípicas (Outliers), esta pesquisa realizou os procedimentos necessários para identificar e eliminar os outliers a fim de não comprometer os resultados do teste da Análise Discriminante em cada exercício social. Posto isso, considera-se atendido este pressuposto. 


\section{d) Ausência de multicolinearidade}

Segundo Hair Jr et al. (2005), a multicolinearidade ocorre quando duas ou mais variáveis independentes estão altamente correlacionadas, o que significa que uma variável pode ser explicada ou prevista por outras variáveis. Dessa forma, a presença de multicolinearidade entre variáveis pode afetar os resultados de classificação da análise discriminante.

Esse autor cita duas das medidas mais comuns para avaliar a colinearidade entre duas ou mais variáveis: o valor de tolerância e o fator de inflação da variância (VIF), as quais denotam o grau em que cada variável independente é explicada pelas demais variáveis independentes.

Tolerância é a quantia de variabilidade da variável independente selecionada não explicada pelas outras variáveis independentes. Assim, quanto menor o valor de tolerância maior será a colinearidade (HAIR JR et al., 2005). Esta pesquisa considera indícios de multicolinearidade quando a tolerância estiver acima de 0,10.

Quanto ao VIF, este é o inverso da Tolerância. Segundo este autor, pode ser expressa como VIF = 1/Tolerância. Além disso, se o valor de referência comum é uma tolerância de 0,10, então corresponde a um valor de VIF acima de 10.

$\mathrm{Na}$ Tabela 4, podem-se verificar os resultados dos testes de Multicolinearidade para as amostras dos anos de 2010 a 2014:

Tabela 4 - Resultado dos Testes de Multicolinearidadade nas amostras anuais

\begin{tabular}{c|c|c|c|c|c|c|c|c|c|c|}
\cline { 2 - 11 } & \multicolumn{2}{|c|}{$\mathbf{2 0 1 0}$} & \multicolumn{2}{c|}{$\mathbf{2 0 1 1}$} & \multicolumn{2}{c|}{$\mathbf{2 0 1 2}$} & \multicolumn{2}{c|}{$\mathbf{2 0 1 3}$} & \multicolumn{2}{c|}{$\mathbf{2 0 1 4}$} \\
\cline { 2 - 11 } & Tolerância & VIF & Tolerância & VIF & Tolerância & VIF & Tolerância & VIF & Tolerância & VIF \\
\hline $\mathbf{X}_{\mathbf{1}}$ & 0,08 & 12,78 & 0,04 & 27,58 & 0,02 & 42,99 & 0,03 & 33,02 & 0,07 & 13,87 \\
\hline $\mathbf{X}_{\mathbf{2}}$ & 0,31 & 3,24 & 0,41 & 2,43 & 0,28 & 3,62 & 0,48 & 2,10 & 0,43 & 2,32 \\
\hline $\mathbf{X}_{\mathbf{3}}$ & 0,16 & 6,35 & 0,05 & 19,06 & 0,06 & 16,81 & 0,10 & 9,70 & 0,15 & 6,71 \\
\hline $\mathbf{X}_{\mathbf{4}}$ & 0,05 & 22,17 & 0,04 & 23,40 & 0,11 & 9,11 & 0,12 & 8,57 & 0,11 & 8,79 \\
\hline $\mathbf{X}_{\mathbf{5}}$ & 0,51 & 1,96 & 0,36 & 2,79 & 0,50 & 1,99 & 0,40 & 2,51 & 0,39 & 2,55 \\
\hline $\mathbf{X}_{\mathbf{6}}$ & 0,06 & 15,53 & 0,04 & 28,72 & 0,13 & 7,69 & 0,09 & 11,14 & 0,12 & 8,52 \\
\hline $\mathbf{X}_{\mathbf{7}}$ & 0,04 & 24,52 & 0,01 & 93,59 & 0,08 & 12,34 & 0,14 & 7,09 & 0,07 & 13,67 \\
\hline $\mathbf{X}_{\mathbf{8}}$ & 0,07 & 13,56 & 0,07 & 13,96 & 0,36 & 2,79 & 0,33 & 3,06 & 0,26 & 3,91 \\
\hline $\mathbf{X}_{\mathbf{9}}$ & 0,03 & 30,67 & 0,01 & 95,68 & 0,12 & 8,52 & 0,29 & 3,40 & 0,08 & 12,86 \\
\hline $\mathbf{X}_{\mathbf{1 0}}$ & 0,81 & 1,24 & 0,60 & 1,66 & 0,52 & 1,91 & 0,77 & 1,30 & 0,58 & 1,72 \\
\hline $\mathbf{X}_{\mathbf{1 1}}$ & 0,06 & 15,88 & 0,03 & 33,77 & 0,76 & 1,31 & 0,85 & 1,17 & 0,70 & 1,43 \\
\hline $\mathbf{X}_{\mathbf{1 2}}$ & 0,23 & 4,37 & 0,32 & 3,16 & 0,35 & 2,83 & 0,41 & 2,43 & 0,43 & 2,31 \\
\hline $\mathbf{X}_{\mathbf{1 3}}$ & 0,09 & 11,72 & 0,06 & 16,47 & 0,12 & 8,32 & 0,11 & 8,86 & 0,15 & 6,68 \\
\hline $\mathbf{X}_{\mathbf{1 4}}$ & 0,07 & 13,86 & 0,12 & 8,07 & 0,45 & 2,23 & 0,54 & 1,87 & 0,86 & 1,16 \\
\hline
\end{tabular}

Fonte: Dados da pesquisa realizada no SPSS (2016). 
Os resultados indicados na Tabela 4 demonstram multicolinearidade entre algumas variáveis nas amostras anuais. Entretanto, antes de efetuar alguma medida corretiva, o autor Mário (2009) recomenda analisar os resultados do Teste F-Anova e da matriz de correlação que evidenciam as variáveis com menor nível de significância e que possuam alta correlação.

\section{e) Homogeneidade das matrizes de variância-covariância}

Este pressuposto tem como objetivo que as matrizes de dispersão e covariância sejam iguais, o que será analisado a partir dos resultados do Teste Box's M que testa a $\mathrm{H}_{0}$ de igualdade de matrizes de covariância através do nível de significância obtido (MÁRIO, 2009).

Tabela 5 - Resultados do Teste Box's M nas amostras anuais

\begin{tabular}{c|c|c|c|c|c|c}
\hline \multicolumn{2}{c|}{ Exercícios } & $\mathbf{2 0 1 0}$ & $\mathbf{2 0 1 1}$ & $\mathbf{2 0 1 2}$ & $\mathbf{2 0 1 3}$ & $\mathbf{2 0 1 4}$ \\
\hline \multicolumn{2}{c}{ Box's M } & 16,803 & 11,299 & 28,567 & 14,363 & 31,85 \\
\hline \multirow{4}{*}{ F } & Aprox. & 5,177 & 3,485 & 4,222 & 2,123 & 9,741 \\
\cline { 2 - 7 } & df1 & 3 & 3 & 6 & 6 & 3 \\
\cline { 2 - 8 } & df2 & 414119,78 & 177952,75 & 6016,462 & 6016,462 & 27005,364 \\
\cline { 2 - 8 } & Sig. & 0,001 & 0,015 & 0,000 & 0,048 & 0,000 \\
\hline
\end{tabular}

Fonte: Dados da pesquisa realizada no SPSS (2016).

Nesse caso, os testes realizados indicam violação dessa premissa em todos os exercícios, uma vez que, utilizando-se de um nível de significância de 0,05, os resultados obtidos no teste foram menores. Como a homogeneidade das matrizes foi violada, entende-se que pode haver um aumento na probabilidade de classificar observações no grupo que possuir maior dispersão.

Apesar dos resultados encontrados, decidiu-se prosseguir na análise dos resultados para verificar qual será o desempenho da função obtida.

\subsection{ESTIMAÇÃO DA FUNÇÃO DISCRIMINANTE}

Uma vez realizada a observação dos pressupostos, o próximo passo é configurar os procedimentos para a estimação da Função Discriminante no SPSS.

Esse programa dá a opção para o pesquisador escolher entre dois métodos computacionais para determinar a função: o método simultâneo (direto) e o método 
stepwise (HAIR Jr et al., 2005). O método direto considera todas as variáveis independentes para determinar a função discriminante, isto é, sem considerar o poder discriminatório de cada variável. De outro modo, o método stepwise realiza a inclusão das variáveis independentes na função discriminante, uma por vez, com base em seu poder discriminatório.

Dessa forma, Hair Jr et al. (2005) consideram que o método stepwise é útil por considerar um número relativamente grande de variáveis independentes para inclusão na função; ao passo que ele seleciona a próxima melhor variável em cada etapa, elimina aquelas que não são úteis na discriminação entre os grupos e, por fim, identifica um conjunto reduzido de variáveis.

A primeira informação gerada pelo SPSS corresponde a um resumo geral, em que se identificam as amostras de análise (casos válidos), que foram utilizadas para gerar a função, e a amostra de teste (casos não selecionados) dos anos de 2010 a 2014, conforme Tabela 6 a seguir.

Tabela 6 - Resumo do processamento das amostras de análise

\begin{tabular}{lc|cc|c|c|c|c|c|c|c|c}
\hline & & \multicolumn{2}{|c|}{$\mathbf{2 0 1 0}$} & \multicolumn{2}{c|}{$\mathbf{2 0 1 1}$} & \multicolumn{2}{c|}{$\mathbf{2 0 1 2}$} & \multicolumn{2}{c|}{$\mathbf{2 0 1 3}$} & \multicolumn{2}{c}{$\mathbf{2 0 1 4}$} \\
\hline & $\mathbf{N}$ & $\mathbf{\%}$ & $\mathbf{N}$ & $\mathbf{\%}$ & $\mathbf{N}$ & $\mathbf{\%}$ & $\mathbf{N}$ & $\mathbf{\%}$ & $\mathbf{N}$ & $\mathbf{\%}$ \\
\hline Válido & 31 & $49,2 \%$ & 31 & $50,0 \%$ & 31 & $50,8 \%$ & 31 & $50,8 \%$ & 30 & $49,2 \%$ \\
\hline & $\begin{array}{c}\text { Não } \\
\text { selecionado }\end{array}$ & 32 & $50,8 \%$ & 31 & $50,0 \%$ & 30 & $49,2 \%$ & 30 & $49,2 \%$ & 31 & $50,8 \%$ \\
\hline Excluídos & Total & 32 & $50,8 \%$ & 31 & $50,0 \%$ & 30 & $49,2 \%$ & 30 & $49,2 \%$ & 31 & $50,8 \%$ \\
\hline Total & & 63 & $100,0 \%$ & 62 & $100,0 \%$ & 61 & $100,0 \%$ & 61 & $100,0 \%$ & 61 & $100,0 \%$ \\
\hline
\end{tabular}

Fonte: Dados da pesquisa realizada no SPSS (2016).

Em seguida, apresentam-se os resultados do teste de igualdade de médias dos grupos, o qual tem por finalidade identificar quais variáveis são as melhores discriminadoras para os grupos em cada exercício social. Segundo Mário (2009), a análise desse teste se dá em função da estatística Wilks’lambda (quanto maior a estatística da variável, melhor a discriminação dos grupos) e do teste F-Anova (quanto menor o nível de significância, isto é, menor que 0,05 , indicam diferença significante entre as médias do grupo). 
Tabela 7 - Teste de igualdade de médias de grupos em cada exercício social

\begin{tabular}{|c|c|c|c|c|c|c|c|c|c|c|c|c|c|c|c|c|c|c|c|c|c|c|c|c|c|}
\hline & \multicolumn{5}{|c|}{2010} & \multicolumn{5}{|c|}{2011} & \multicolumn{5}{|c|}{2012} & \multicolumn{5}{|c|}{2013} & \multicolumn{5}{|c|}{2014} \\
\hline & $\begin{array}{c}\text { Lambda } \\
\text { de } \\
\text { Wilks }\end{array}$ & $\mathrm{F}$ & df1 & df2 & Sig. & $\begin{array}{c}\text { Lambda } \\
\text { de } \\
\text { Wilks }\end{array}$ & $\mathrm{F}$ & df1 & df2 & Sig. & $\begin{array}{c}\text { Lambda } \\
\text { de } \\
\text { Wilks }\end{array}$ & $\mathrm{F}$ & df1 & df2 & Sig. & $\begin{array}{c}\text { Lambda } \\
\text { de } \\
\text { Wilks }\end{array}$ & $\mathrm{F}$ & df1 & df2 & Sig. & $\begin{array}{c}\text { Lambda } \\
\text { de } \\
\text { Wilks } \\
\end{array}$ & $\mathrm{F}$ & df1 & df2 & Sig. \\
\hline X1 & 0,87 & 4,24 & 1 & 29 & 0,05 & 0,91 & 3,06 & 1 & 29 & 0,09 & 0,95 & 1,65 & 1 & 29 & 0,21 & 0,95 & 1,46 & 1 & 29 & 0,24 & 0,97 & 0,99 & 1 & 28 & 0,33 \\
\hline $\mathrm{X} 2$ & 0,99 & 0,19 & 1 & 29 & 0,66 & 0,99 & 0,36 & 1 & 29 & 0,56 & 1,00 & 0,13 & 1 & 29 & 0,73 & 1,00 & 0,12 & 1 & 29 & 0,73 & 0,99 & 0,26 & 1 & 28 & 0,61 \\
\hline X3 & 0,90 & 3,10 & 1 & 29 & 0,09 & 0,88 & 4,01 & 1 & 29 & 0,06 & 0,92 & 2,58 & 1 & 29 & 0,12 & 0,92 & 2,70 & 1 & 29 & 0,11 & 1,00 & 0,00 & 1 & 28 & 0,95 \\
\hline $\mathrm{X} 4$ & 0,99 & 0,18 & 1 & 29 & 0,68 & 0,97 & 0,94 & 1 & 29 & 0,34 & 0,76 & 9,04 & 1 & 29 & 0,01 & 0,95 & 1,57 & 1 & 29 & 0,22 & 0,78 & 7,88 & 1 & 28 & 0,01 \\
\hline $\mathrm{X5}$ & 0,98 & 0,49 & 1 & 29 & 0,49 & 0,77 & 8,75 & 1 & 29 & 0,01 & 0,98 & 0,51 & 1 & 29 & 0,48 & 0,99 & 0,42 & 1 & 29 & 0,52 & 0,99 & 0,28 & 1 & 28 & 0,60 \\
\hline X6 & 0,86 & 4,61 & 1 & 29 & 0,04 & 0,96 & 1,23 & 1 & 29 & 0,28 & 0,72 & 11,18 & 1 & 29 & 0,00 & 0,93 & 2,05 & 1 & 29 & 0,16 & 0,79 & 7,38 & 1 & 28 & 0,01 \\
\hline X7 & 0,95 & 1,50 & 1 & 29 & 0,23 & 0,80 & 7,33 & 1 & 29 & 0,01 & 0,94 & 1,71 & 1 & 29 & 0,20 & 0,96 & 1,09 & 1 & 29 & 0,31 & 1,00 & 0,00 & 1 & 28 & 0,97 \\
\hline X8 & 0,96 & 1,34 & 1 & 29 & 0,26 & 1,00 & 0,00 & 1 & 29 & 0,98 & 1,00 & 0,00 & 1 & 29 & 0,97 & 1,00 & 0,16 & 1 & 29 & 0,69 & 0,91 & 2,89 & 1 & 28 & 0,10 \\
\hline X9 & 0,97 & 0,78 & 1 & 29 & 0,38 & 0,77 & 8,74 & 1 & 29 & 0,01 & 0,93 & 2,35 & 1 & 29 & 0,14 & 0,99 & 0,20 & 1 & 29 & 0,66 & 0,99 & 0,32 & 1 & 28 & 0,58 \\
\hline $\mathrm{X10}$ & 0,83 & 5,82 & 1 & 29 & 0,02 & 0,88 & 4,14 & 1 & 29 & 0,05 & 0,85 & 5,17 & 1 & 29 & 0,03 & 0,87 & 4,36 & 1 & 29 & 0,05 & 0,66 & 14,37 & 1 & 28 & 0,00 \\
\hline X11 & 0,91 & 3,03 & 1 & 29 & 0,09 & 1,00 & 0,05 & 1 & 29 & 0,83 & 0,94 & 1,82 & 1 & 29 & 0,19 & 0,98 & 0,72 & 1 & 29 & 0,40 & 0,96 & 1,14 & 1 & 28 & 0,30 \\
\hline X12 & 0,94 & 1,88 & 1 & 29 & 0,18 & 0,90 & 3,08 & 1 & 29 & 0,09 & 0,99 & 0,43 & 1 & 29 & 0,52 & 0,85 & 5,24 & 1 & 29 & 0,03 & 0,93 & 1,99 & 1 & 28 & 0,17 \\
\hline $\mathrm{X13}$ & 0,86 & 4,60 & 1 & 29 & 0,04 & 0,98 & 0,61 & 1 & 29 & 0,44 & 0,96 & 1,25 & 1 & 29 & 0,27 & 0,98 & 0,49 & 1 & 29 & 0,49 & 0,96 & 1,03 & 1 & 28 & 0,32 \\
\hline X14 & 0,99 & 0,17 & 1 & 29 & 0,68 & 0,70 & 12,17 & 1 & 29 & 0,00 & 1,00 & 0,12 & 1 & 29 & 0,73 & 0,91 & 2,91 & 1 & 29 & 0,10 & 1,00 & 0,02 & 1 & 28 & 0,88 \\
\hline
\end{tabular}


$\mathrm{Na}$ Tabela 7, pode-se observar que os resultados das estatísticas Wilks'lambda indicam que as variáveis que apresentam maior poder de discriminação entre os grupos são: $\mathrm{X}_{10}$ (Crescimento das Vendas) e $\mathrm{X}_{13}$ (Liquidez Geral) em 2010; $\mathrm{X}_{5}$ (Liquidez Corrente) e $\mathrm{X}_{14}$ (Margem Ebtida) em 2011; $\mathrm{X}_{2}$ (Giro do Ativo), $\mathrm{X}_{6}$ (Q de Tobin) e $\mathrm{X}_{10}$ (Crescimento das Vendas) em 2012; $\mathrm{X}_{3}$ (ROE), $\mathrm{X}_{10}$ (Crescimento das Vendas) e $\mathrm{X}_{12}$

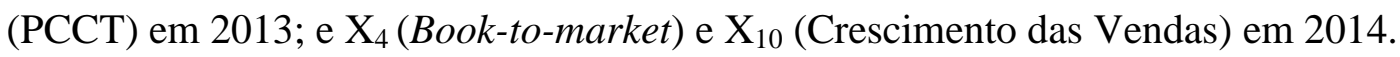

Comparando-se estes índices com os estudos anteriores, têm-se em comum as variáveis com capacidade discriminatória: o índice de Liquidez Geral, que foi considerado significativo nas funções discriminantes do estudo de Teixeira et al. (2013), e o índice ROE, que no estudo de Mota e Tavares (2015) indicou capacidade discriminatória para classificar os indivíduos nos grupos propostos.

Esta informação pode ser confirmada na tabela 8 abaixo, que revela as variáveis inseridas em cada passo pelo método stepwise na análise discriminante.

Tabela 8 - Resultado das Variáveis Inseridas em cada etapa por exercício social

\begin{tabular}{|c|c|c|c|c|c|c|c|c|c|c|}
\hline & \multirow{3}{*}{ Etapa } & \multirow{3}{*}{ Inseridas } & \multicolumn{8}{|c|}{ Lambda de Wilks } \\
\hline & & & \multirow{2}{*}{ Estatística } & \multirow{2}{*}{ df1 } & \multirow{2}{*}{ df2 } & \multirow{2}{*}{ df3 } & \multicolumn{4}{|c|}{ F exato } \\
\hline & & & & & & & Estatística & df1 & df2 & Sig. \\
\hline \multirow{2}{*}{2010} & 1 & $\mathbf{X}_{10}$ & 0,833 & 1 & 1 & 29 & 5,82 & 1 & 29 & 0,022 \\
\hline & 2 & $\mathbf{X}_{13}$ & 0,713 & 2 & 1 & 29 & 5,645 & 2 & 28 & 0,009 \\
\hline \multirow{2}{*}{2011} & 1 & $\mathbf{X}_{14}$ & 0,704 & 1 & 1 & 29 & 12,165 & 1 & 29 & 0,002 \\
\hline & 2 & $\mathbf{X}_{5}$ & 0,602 & 2 & 1 & 29 & 9,259 & 2 & 28 & 0,001 \\
\hline \multirow{3}{*}{2012} & 1 & $\mathbf{X}_{6}$ & 0,722 & 1 & 1 & 29 & 11,177 & 1 & 29 & 0,002 \\
\hline & 2 & $\mathbf{X}_{10}$ & 0,617 & 2 & 1 & 29 & 8,686 & 2 & 28 & 0,001 \\
\hline & 3 & $\mathbf{X}_{2}$ & 0,513 & 3 & 1 & 29 & 8,556 & 3 & 27 & 0,000 \\
\hline \multirow{3}{*}{2013} & 1 & $\mathbf{X}_{12}$ & 0,847 & 1 & 1 & 29 & 5,242 & 1 & 29 & 0,030 \\
\hline & 2 & $\mathbf{X}_{10}$ & 0,712 & 2 & 1 & 29 & 5,652 & 2 & 28 & 0,009 \\
\hline & 3 & $\mathbf{X}_{\mathbf{3}}$ & 0,589 & 3 & 1 & 29 & 6,278 & 3 & 27 & 0,002 \\
\hline \multirow{2}{*}{2014} & 1 & $\mathbf{X}_{10}$ & 0,661 & 1 & 1 & 28 & 14,365 & 1 & 28 & 0,001 \\
\hline & 2 & $\mathbf{X}_{4}$ & 0,457 & 2 & 1 & 28 & 16,02 & 2 & 27 & 0,000 \\
\hline
\end{tabular}

Em cada etapa, a variável que minimiza o Lambda de Wilks geral é inserida. ${ }^{\text {a,b,c,d }}$

a. O número máximo de etapas é 28.

b. A significância máxima de $\mathrm{F}$ a ser inserida é 0,05 .

c. A significância mínima de F a ser removida é 0,10 .

d. Nível f, tolerância ou VIN insuficiente para cálculos adicionais.

Fonte: Dados da pesquisa realizada no SPSS. 
Em cada exercício, observa-se que o sistema selecionou, em cada etapa, as melhores variáveis para a função discriminante, considerando-se os níveis de significância obtidos dentro do intervalo de confiança de 0,05 e 0,10 para inserir e remover a variável da função.

Isso se confirma pelo fato de que a primeira variável selecionada para determinar a função discriminante, em cada exercício, é aquela que tem maior poder discriminante, isto é, o maior valor para Wilks'Lambda e menor valor de sig do teste FAnova. Outro fato da melhoria do poder discriminatório da função é observado após a inclusão de novas variáveis, em que se verifica, na segunda etapa dos anos de 2010, 2011 e 2014 e nas terceiras etapas do ano 2012 e 2013, que a inclusão dessas novas variáveis resultou na diminuição da estatística Wilks'Lambda.

Além disso, o SPSS fornece outras informações que explicam a inserção dessas variáveis nas funções discriminantes, quais sejam sobre multicolinearidade, estatística F, para remoção das variáveis, e capacidade de explicação, conforme Tabela 9 a seguir.

\begin{tabular}{|c|c|c|c|c|c|}
\hline Ano & \multicolumn{2}{|c|}{ Etapa } & Tolerância & Sig. de F a ser & Wilks'Lambda \\
\hline \multirow{3}{*}{2010} & 1 & $\mathbf{X}_{10}$ & 1,00 & 0,022 & \\
\hline & \multirow{2}{*}{2} & $\mathbf{X}_{10}$ & 0,988 & 0,022 & 0,863 \\
\hline & & $\mathbf{X}_{13}$ & 0,988 & 0,038 & 0,833 \\
\hline \multirow{3}{*}{2011} & 1 & $X_{14}$ & 1,00 & 0,002 & \\
\hline & \multirow{2}{*}{2} & $\mathbf{X}_{14}$ & 0,992 & 0,01 & 0,768 \\
\hline & & $\mathbf{X}_{5}$ & 0,992 & 0,037 & 0,704 \\
\hline \multirow{6}{*}{2012} & 1 & $X_{6}$ & 1 & 0,002 & \\
\hline & \multirow{2}{*}{2} & $X_{6}$ & 0,991 & 0,003 & 0,849 \\
\hline & & $X_{10}$ & 0,991 & 0,038 & 0,722 \\
\hline & \multirow{3}{*}{3} & $\mathbf{X}_{6}$ & 0,777 & 0 & 0,821 \\
\hline & & $\mathbf{X}_{10}$ & 0,853 & 0,009 & 0,662 \\
\hline & & $\mathbf{X}_{2}$ & 0,715 & 0,027 & 0,617 \\
\hline \multirow{6}{*}{2013} & 1 & $X_{12}$ & 1 & 0,03 & \\
\hline & \multirow{2}{*}{2} & $\mathbf{X}_{12}$ & 0,967 & 0,019 & 0,869 \\
\hline & & $X_{10}$ & 0,967 & 0,029 & 0,847 \\
\hline & \multirow{3}{*}{3} & $\mathbf{X}_{12}$ & 0,959 & 0,022 & 0,718 \\
\hline & & $\mathbf{X}_{10}$ & 0,817 & 0,006 & 0,783 \\
\hline & & $\mathbf{X}_{3}$ & 0,844 & 0,025 & 0,712 \\
\hline
\end{tabular}


(Conclui)

\begin{tabular}{c|c|c|c|c|c}
\hline \multirow{2}{*}{ Ano } & \multicolumn{2}{|c|}{ Etapa } & Tolerância & $\begin{array}{c}\text { Sig. de F a ser } \\
\text { removida }\end{array}$ & Wilks'Lambda \\
\hline \multirow{2}{*}{$\mathbf{2 0 1 4}$} & 1 & $\mathbf{X}_{\mathbf{1 0}}$ & 1,00 & 0,001 & \\
\cline { 2 - 6 } & 2 & $\mathbf{X}_{\mathbf{4}}$ & 0,886 & 0 & 0,78 \\
& $\mathbf{X}_{\mathbf{1 0}}$ & 0,886 & 0,002 & 0,661 \\
\hline
\end{tabular}

Fonte: Dados da pesquisa realizada no SPSS (2016).

Nos anos de 2010, 2011 e 2014, como se identificou o problema de multicolinearidade entre essas variáveis, observa-se que o nível de explicação de cada variável automaticamente se reduz na última etapa, conforme indicado pelo coeficiente Tolerância. Isso ocorreu porque as variáveis selecionadas $\left(\mathrm{X}_{10}\right.$ e $\mathrm{X}_{13}$ para $2010 ; \mathrm{X}_{14} \mathrm{e} \mathrm{X}_{5}$ para 2011; e $X_{10}$ e $X_{4}$ para 2014) contribuem para a formação de uma função discriminante, porém existe uma explicação que é repetida em cada uma devido à multicolinearidade, conforme explica o autor Mário (2009).

Segundo esse autor, nesses casos, pode-se até considerar a retirada de uma das variáveis, que seria aquelas de maior Lambda, entretanto isso pode resultar em uma função com menor poder de explicação que a atual. Por isso, acredita-se que a multicolinearidade não é razão suficiente para a exclusão de variáveis se o processo stepwise não foi afetado por inteiro (MÁRIO, 2009).

Ademais, através da análise da Estatística $\mathrm{F}$ de remoção, comprova-se que as variáveis inseridas nesses exercícios apresentaram sig menor que 0,05, implicando a sua permanência nas funções discriminantes.

Posto isso, a Tabela 10, a seguir, apresenta os coeficientes das variáveis inseridas assim como o valor da sua constante, nas funções discriminantes:

Tabela 10 - Coeficientes das funções discriminantes canônicas

\begin{tabular}{|c|c|c|c|c|c|c|c|c|c|}
\hline \multicolumn{2}{|c|}{2010} & \multicolumn{2}{|c|}{2011} & \multicolumn{2}{|c|}{2012} & \multicolumn{2}{|c|}{2013} & \multicolumn{2}{|c|}{2014} \\
\hline \multicolumn{2}{|c|}{ Função } & \multicolumn{2}{|c|}{ Função } & \multicolumn{2}{|c|}{ Função } & \multicolumn{2}{|c|}{ Função } & \multicolumn{2}{|c|}{ Função } \\
\hline $\mathrm{X}_{10}$ & 0,025 & $\mathrm{X}_{5}$ & $-0,830$ & $X_{2}$ & $-1,557$ & $\mathrm{X}_{3}$ & 0,044 & $\mathrm{X}_{4}$ & 0,636 \\
\hline $\mathrm{X}_{13}$ & 0,578 & $\mathrm{X}_{14}$ & 1,413 & $\mathrm{X}_{6}$ & 1,500 & $\mathrm{X}_{10}$ & $-0,034$ & $\mathrm{X}_{10}$ & 0,030 \\
\hline Constante & $-2,268$ & Constante & 0,740 & $\mathrm{X}_{10}$ & 0,042 & $\mathrm{X}_{12}$ & 3,442 & Constante & $-1,463$ \\
\hline & & & & Constante & $-1,566$ & Constante & $-1,869$ & & \\
\hline
\end{tabular}

Coeficientes não padronizados.

Fonte: Dados da pesquisa realizada no SPSS (2016). 
A partir da Tabela 10, pode-se fazer a leitura dos respectivos pesos de cada variável e sua constante na função discriminante. Esta última apresenta-se com valores negativos ao longo do período, com exceção apenas do ano de 2011.

Em 2010, as variáveis $\mathrm{X}_{10}$ (Crescimento das Vendas) e $\mathrm{X}_{13}$ (Liquidez Geral) têm pesos de 0,025 e 0,578, respectivamente, impactando positivamente o resultado da função discriminante $(\mathrm{Zi})$.

No ano de 2011, as variáveis inseridas na função apresentaram valores invertidos de seus coeficientes, isto é, a variável $\mathrm{X}_{5}$ (Liquidez corrente) teve um valor negativo (-0,830), ao passo que a variável $\mathrm{X}_{14}$ (Margem Ebtida) apresentou um coeficiente de valor positivo $(1,413)$ para cálculo do $Z_{i}$ da função discriminante. Nesse caso, enquanto um maior o valor de Margem Ebtida colabora para gerar um valor maior de $Z_{i}$, um maior valor de liquidez de curto prazo provocará um escore discriminante menor.

Esse mesmo entendimento é válido para os anos de 2012 e 2013, em que uma das variáveis apresentou coeficiente negativo. Em 2012, em virtude da variável $\mathrm{X}_{2}$ (Giro do Ativo) apresentar coeficiente negativo $(-1,557)$, entende-se que quanto maior o valor obtido nessa variável o valor do escore discriminante $\mathrm{Z}_{\mathrm{i}}$ tenderá a ser menor. Por outro lado, as variáveis $\mathrm{X}_{6}\left(Q\right.$ de Tobin) e $\mathrm{X}_{10}$ (Crescimento das Vendas) colaboram para gerar um valor maior de $Z_{i}$ através dos seus coeficientes positivos de 1,500 e 0,042, respectivamente.

No ano de 2013, a variável $\mathrm{X}_{10}$ (Crescimento das vendas) obteve um coeficiente negativo de $(-0,034)$ que tenderá a tornar o valor de $\mathrm{Z}_{\mathrm{i}}$ menor, enquanto que as variáveis $\mathrm{X}_{3}$ (ROE) e $\mathrm{X}_{12}$ (Participação do Passivo Circulante sobre o Exigível total) colaborarão para atingir um maior valor de $\mathrm{Z}_{\mathrm{i}}$.

Por fim, no ano de 2014, as variáveis $\mathrm{X}_{4}$ (Book-to-market) e $\mathrm{X}_{10}$ (Crescimento das Vendas) apresentaram pesos de 0,636 e 0,030, respectivamente, e, assim como em 2010, irão contribuir positivamente para o valor do resultado da função discriminante $\left(\mathrm{Z}_{\mathrm{i}}\right)$.

De posse dos dados da Tabela 10, apresentam-se abaixo as funções discriminantes para uma determinada Empresa $Y$ nos anos de 2010, 2011, 2012, 2013 e 2014, respectivamente:

$$
\begin{aligned}
& Z_{Y}=-2,268+0,025 X_{10}+0,578 X_{13} \\
& Z_{Y}=0,74-0,83 X_{5}+1,413 X_{14}
\end{aligned}
$$




$$
\begin{aligned}
& Z_{Y}=-1,566-1,557 X_{2}+1,5 X_{6}+0,042 X_{10} \\
& Z_{Y}=-1,869+0,044 X_{3}-0,034 X_{10}+3,442 X_{12} \\
& Z_{Y}=-1,463+0,636 X_{4}+0,03 X_{10}
\end{aligned}
$$

Para a classificação de cada empresa em um grupo, são geradas duas funções de classificação, denominadas funções lineares de Fisher, conforme apresenta a Tabela 11 a seguir. Dessa forma, apresenta-se, para cada grupo, a sua função de classificação e, consequentemente, os dois escores de classificação para cada empresa: um associado ao grupo das empresas Vencedoras e outro ao grupo de Perdedoras. Por fim, a empresa será classificada no grupo que apresentar maior escore de classificação (HAIR Jr et al.,

\begin{tabular}{|c|c|c|c|}
\hline \multirow{2}{*}{ Exercícios } & \multirow{2}{*}{ Variáveis } & \multicolumn{2}{|c|}{ Classificação } \\
\hline & & Vencedoras & Perdedoras \\
\hline \multirow{3}{*}{2010} & $\mathrm{X}_{10}$ & 0,059 & 0,028 \\
\hline & $\mathrm{X}_{13}$ & 2,121 & 1,408 \\
\hline & Constante & $-5,397$ & $-2,33$ \\
\hline \multirow{3}{*}{2011} & $\mathrm{X}_{5}$ & 2,819 & 4,126 \\
\hline & $\mathrm{X}_{14}$ & 3,511 & 1,286 \\
\hline & (Constante) & $-4,195$ & $-5,256$ \\
\hline \multirow{4}{*}{2012} & $\mathrm{X}_{2}$ & $-0,333$ & 2,604 \\
\hline & $\mathrm{X}_{6}$ & 4,57 & 1,739 \\
\hline & $\mathrm{X}_{10}$ & 0,072 & $-0,008$ \\
\hline & (Constante) & $-5,434$ & $-2,601$ \\
\hline \multirow{4}{*}{2013} & $\mathrm{X}_{3}$ & 0,017 & 0,088 \\
\hline & $\mathrm{X}_{10}$ & 0,008 & $-0,047$ \\
\hline & $\mathrm{X}_{12}$ & 10,826 & 16,391 \\
\hline & (Constante) & $-3,057$ & $-6,184$ \\
\hline \multirow{3}{*}{2014} & $\mathrm{X}_{4}$ & 1,846 & 0,48 \\
\hline & $\mathrm{X}_{10}$ & 0,059 & $-0,006$ \\
\hline & (Constante) & $-3,428$ & $-1,153$ \\
\hline
\end{tabular}
2005).

Tabela 11 - Detalhamento dos Coeficientes das funções de classificação por exercício

A partir da análise dos coeficientes, percebe-se que, em 2010, as empresas que apresentaram maiores valores para as variáveis $\mathrm{X}_{10}$ (Crescimento das Vendas) e $\mathrm{X}_{13}$ (Liquidez Geral) tendem a ser classificadas no grupo de Vencedoras. Isso pode indicar 
aumento nas vendas à vista e, consequentemente, aumento na disponibilidade dos recursos, ou, até mesmo, a liquidação antecipada das obrigações junto aos fornecedores. Assim, o grau de solvência de sua atividade operacional é expresso por meio desses índices.

No exercício de 2011, os coeficientes de maiores valores estão com posições invertidas na classificação, isto é, as entidades que apresentaram maior valor para a variável $\mathrm{X}_{5}$ (Liquidez corrente) tendem a ser classificadas no grupo de Perdedoras, ao passo que aquelas que obtiveram maiores valores na variável $\mathrm{X}_{14}$ (Margem Ebtida) tendem a ser classificadas no grupo de Vencedoras. Esse indicativo provavelmente relaciona-se àquelas empresas que auferiram um bom desempenho na geração de recursos decorrentes da atividade fim do negócio, e, por isso, um maior valor de Margem Ebtida reflete a capacidade dessa entidade em gerar bom desempenho no futuro. Por sua vez, o alto valor do índice de Liquidez Corrente pode estar relacionado àquelas empresas que são avessas ao risco, isto é, que preferem ter uma boa relação de liquidez com os terceiros do que efetivamente traçar metas pra crescimento no mercado.

Em 2012, apesar de a função discriminante estar composta de três variáveis diferentes, os coeficientes da variável $\mathrm{X}_{2}$ (Giro do Ativo) possuem posições invertidas na classificação dos grupos em relação às outras duas variáveis $\mathrm{X}_{6}\left(Q\right.$ de Tobin) e $\mathrm{X}_{10}$ (Crescimento das Vendas). Nesse caso, as empresas que apresentarem alto valor investido em Giro do Ativo tendem a ser classificadas no grupo de Perdedoras, enquanto aquelas que alavancarem suas vendas e demonstrarem ao mercado o seu potencial de valorização da empresa através do valor do índice $Q$ de Tobin estarão propensas a serem classificadas no grupo de Vencedoras.

De forma semelhante, no ano 2013, os coeficientes da variável $\mathrm{X}_{10}$ (Crescimento das Vendas) expressa que as empresas que alavancaram suas vendas tenderão a ser classificadas no grupo de Vencedoras, ao passo que as empresas que apresentaram maior nível de Retorno ao Patrimônio Líquido e Participação do passivo circulante sobre o exigível total estarão propensas a serem classificadas no grupo de Perdedoras. Nesse caso, entende-se que as empresas que optaram em alavancar seus investimentos no patrimônio através da aquisição de empréstimos e financiamento de curto prazo não obtiveram bons desempenhos operacionais e, assim, não se classificam como boas alternativas de investimento.

Por fim, no ano de 2014, as empresas que obtiveram maiores valores nos índices Book-to-market e Crescimento das vendas serão classificadas no grupo de Vencedoras. 
Nesse caso, percebe-se que o bom desempenho operacional refletido pelo crescimento das vendas de algumas empresas também impactaram o valor de suas ações no mercado acionário, de modo que o valor da ação no mercado permaneceu superior ao seu valor contábil. Assim, é possível que a observação desses dois índices venha a contribuir para que o investidor seja capaz de selecionar uma carteira de ações com maior e melhor potencial de retorno dos recursos investidos.

Além disso, a partir desses resultados, observa-se que o índice de Crescimento das Vendas foi o índice que mais se repetiu nas funções discriminantes, estando presente nessas funções em quatro dos cinco anos analisados nesta pesquisa. Pode-se inferir, então, que esse índice econômico-financeiro possui capacidade preditiva em selecionar as empresas com maior potencial de desempenho operacional e com forte indicativo de gerar lucros e retornos aos seus investidores.

Para finalizar o processo de classificação da amostra, serão calculados os escores $\mathrm{Z}$ discriminantes para cada empresa a partir das funções dispostas na Tabela 12. Com todos os escores apurados, calcula-se a média de cada grupo, que servirá de base para cálculo do ponto de corte (cut off point) e, finalmente, o valor médio entre as médias de cada grupo, que servirá para discriminar a qual grupo pertence aquela empresa.

Para isso, são calculados os centróides dos grupos, isto é, os valores médios dos escores $\mathrm{Z}$ das empresas de cada grupo, e as respectivas probabilidades a priori de classificação de uma empresa entre os grupos, com base no número de empresas de cada grupo na amostra de análise, conforme mostram as Tabelas 12 e 13.

Tabela 12 - Funções de centróides dos grupos

\begin{tabular}{c|c|c|c|c|c}
\hline \multirow{2}{*}{ Grupos } & $\mathbf{2 0 1 0}$ & $\mathbf{2 0 1 1}$ & $\mathbf{2 0 1 2}$ & $\mathbf{2 0 1 3}$ & $\mathbf{2 0 1 4}$ \\
\cline { 2 - 6 } & Função & Função & Função & Função & Função \\
\hline Vencedoras & 0,677 & 0,812 & 0,913 & $-0,782$ & 0,859 \\
\hline Perdedoras & $-0,557$ & $-0,762$ & $-0,974$ & 0,834 & $-1,289$ \\
\hline
\end{tabular}

Fonte: Dados da pesquisa realizada no SPSS (2016).

Tabela 13 - Probabilidades a priori para os grupos

\begin{tabular}{|c|c|c|c|c|c|c|c|c|c|c|c|c|c|c|c|}
\hline \multirow{3}{*}{ Grupos } & \multicolumn{3}{|c|}{2010} & \multicolumn{3}{|c|}{2011} & \multicolumn{3}{|c|}{2012} & \multicolumn{3}{|c|}{2013} & \multicolumn{3}{|c|}{2014} \\
\hline & \multirow{2}{*}{$\begin{array}{c}\text { A } \\
\text { priori }\end{array}$} & \multicolumn{2}{|c|}{$\begin{array}{c}\text { Casos } \\
\text { utilizados }\end{array}$} & \multirow{2}{*}{$\begin{array}{c}\text { A } \\
\text { priori }\end{array}$} & \multicolumn{2}{|c|}{$\begin{array}{c}\text { Casos } \\
\text { utilizados }\end{array}$} & \multirow{2}{*}{$\begin{array}{c}\mathrm{A} \\
\text { priori }\end{array}$} & \multicolumn{2}{|c|}{$\begin{array}{c}\text { Casos } \\
\text { utilizados }\end{array}$} & \multirow{2}{*}{$\begin{array}{c}\text { A } \\
\text { priori }\end{array}$} & \multicolumn{2}{|c|}{$\begin{array}{c}\text { Casos } \\
\text { utilizados }\end{array}$} & \multirow{2}{*}{$\begin{array}{c}\text { A } \\
\text { priori }\end{array}$} & \multicolumn{2}{|c|}{$\begin{array}{c}\text { Casos } \\
\text { utilizados }\end{array}$} \\
\hline & & $\begin{array}{c}\mathrm{N} . \\
\text { pond }\end{array}$ & Pond. & & \begin{tabular}{c|} 
N. \\
pond
\end{tabular} & Pond. & & \begin{tabular}{c|}
$\mathrm{N}$. \\
pond
\end{tabular} & Pond. & & $\begin{array}{c}\text { N. } \\
\text { pond }\end{array}$ & Pond. & & $\begin{array}{c}\mathrm{N} . \\
\text { pond }\end{array}$ & Pond. \\
\hline Venc. & 0,452 & 14 & 14 & 0,484 & 15 & 15 & 0,516 & 16 & 16 & 0,516 & 16 & 16 & 0,6 & 18 & 18 \\
\hline Perd. & 0,548 & 17 & 17 & 0,516 & 16 & 16 & 0,484 & 15 & 15 & 0,484 & 15 & 15 & 0,4 & 12 & 12 \\
\hline Total & 1 & 31 & 31 & 1 & 31 & 31 & 1 & 31 & 31 & 1 & 31 & 31 & 1 & 30 & 30 \\
\hline
\end{tabular}

Fonte: Dados da pesquisa realizada no SPSS (2016). 
Na Tabela 13, observa-se que, em cada exercício, a probabilidade a priori de classificação é diferente entre os grupos de Perdedores e Vencedores, visto que o número de empresas classificadas em cada grupo diverge a cada ano.

Em razão desse problema do tamanho das amostras, demonstra-se que o ponto corte obtido através das médias não é o ponto ótimo. Assim, faz-se necessária uma ponderação, isto é, uma atribuição de peso aos pontos centróides em função do número de empresas de cada amostra, através da fórmula expressa lá no tópico 5.3.3 Análise discriminante, para que se possam encontrar os valores de $\mathrm{Z}_{\mathrm{EC}}$ de cada exercício analisado.

Tabela 14 - Ponto de corte de cada amostra por exercício

\begin{tabular}{c|c}
\hline Exercício & $\mathbf{Z}_{\mathbf{E C}}$ \\
\hline 2010 & 0,021 \\
\hline 2011 & 0,050 \\
\hline 2012 & $-0,031$ \\
\hline 2013 & 0,026 \\
\hline 2014 & $-0,042$ \\
\hline
\end{tabular}

Fonte: Elaborado pela própria autora.

A partir da Tabela 14, uma empresa $i$, que obteve determinado escore $Z i$, pode ser classificada da seguinte forma:

$\mathrm{Se} \mathrm{Zi}<\mathrm{Zec}$, a empresa será classificada no grupo dos Perdedores;

$\mathrm{Se} \mathrm{Zi}>\mathrm{Zec}$, a empresa será classificada no grupo dos Vencedores.

\subsection{VALIDAÇÃO DA FUNÇÃO DISCRIMINANTE}

A partir da fixação do ponto de corte, faz-se necessário calcular o escore discriminante $\mathrm{Z}_{\mathrm{i}}$ para cada empresa da amostra de análise e de teste para validar a função discriminante usando a matriz de classificação. Esses escores são obtidos a partir dos coeficientes estabelecidos na Tabela 10 para cada exercício.

De posse desses valores, deve-se comparar o valor de $Z_{i}$ de cada empresa e o escore crítico $\mathrm{Z}_{\mathrm{EC}}$ com fins de apurar os quantitativos de erros e acertos. Esses resultados de classificação são apresentados em formato matricial, conforme Tabela 15. 
Tabela 15 - Resultados da classificação em cada exercício social

\begin{tabular}{|c|c|c|c|c|c|c|c|c|c|c|c|c|c|c|c|c|c|c|}
\hline & \multicolumn{3}{|c|}{2010} & \multicolumn{3}{|c|}{2011} & \multicolumn{3}{|c|}{2012} & \multicolumn{3}{|c|}{2013} & \multicolumn{3}{|c|}{2014} \\
\hline & & & & \multicolumn{2}{|c|}{ Grupos previstos } & \multirow{2}{*}{ Total } & \multicolumn{2}{|c|}{ Grupos previstos } & \multirow{2}{*}{ Total } & \multicolumn{2}{|c|}{ Grupos previstos } & \multirow{2}{*}{ Total } & \multicolumn{2}{|c|}{ Grupos previstos } & \multirow{2}{*}{ Total } & \multicolumn{2}{|c|}{ Grupos previstos } & \multirow{2}{*}{ Total } \\
\hline & & & & Venc. & Perd. & & Venc. & Perd. & & Venc. & Perd. & & Venc. & Perd. & & Venc. & Perd. & \\
\hline \multirow{8}{*}{ 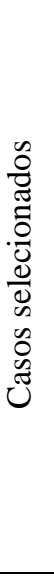 } & \multirow{4}{*}{$\begin{array}{l}\widetilde{\Xi} \\
\stackrel{\Xi}{0} \\
\vec{\Xi}\end{array}$} & \multirow{2}{*}{ 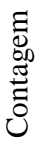 } & Venc. & 6 & 8 & 14 & 10 & 5 & 15 & 14 & 2 & 16 & 12 & 4 & 16 & 16 & 2 & 18 \\
\hline & & & Perd. & 3 & 14 & 17 & 3 & 13 & 16 & 1 & 14 & 15 & 3 & 12 & 15 & 0 & 12 & 12 \\
\hline & & \multirow{2}{*}{$\%$} & Venc. & 42,9 & 57,1 & 100 & 66,7 & 33,3 & 100 & 87,5 & 12,5 & 100 & 75 & 25 & 100 & 88,9 & 11,1 & 100 \\
\hline & & & Perd. & 17,6 & 82,4 & 100 & 18,8 & 81,3 & 100 & 6,7 & 93,3 & 100 & 20 & 80 & 100 & 0 & 100 & 100 \\
\hline & \multirow{4}{*}{ 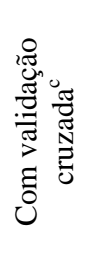 } & \multirow{2}{*}{ 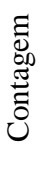 } & Venc. & 6 & 8 & 14 & 10 & 5 & 15 & 14 & 2 & 16 & 11 & 5 & 16 & 16 & 2 & 18 \\
\hline & & & Perd. & 4 & 13 & 17 & 3 & 13 & 16 & 4 & 11 & 15 & 4 & 11 & 15 & 0 & 12 & 12 \\
\hline & & \multirow{2}{*}{$\%$} & Venc. & 42,9 & 57,1 & 100 & 66,7 & 33,3 & 100 & 87,5 & 12,5 & 100 & 68,8 & 31,3 & 100 & 88,9 & 11,1 & 100 \\
\hline & & & Perd. & 23,5 & 76,5 & 100 & 18,8 & 81,3 & 100 & 26,7 & 73,3 & 100 & 26,7 & 73,3 & 100 & 0 & 100 & 100 \\
\hline \multirow{4}{*}{ 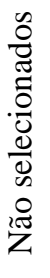 } & \multirow{4}{*}{ 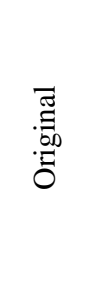 } & \multirow{2}{*}{ 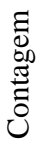 } & Venc. & 4 & 13 & 17 & 8 & 7 & 15 & 11 & 4 & 15 & 6 & 9 & 15 & 10 & 3 & 13 \\
\hline & & & Perd. & 2 & 13 & 15 & 5 & 11 & 16 & 2 & 13 & 15 & 10 & 5 & 15 & 2 & 16 & 18 \\
\hline & & \multirow{2}{*}{$\%$} & Venc. & 23,5 & 76,5 & 100 & 53,3 & 46,7 & 100 & 73,3 & 26,7 & 100 & 40 & 60 & 100 & 76,9 & 23,1 & 100 \\
\hline & & & Perd. & 13,3 & 86,7 & 100 & 31,3 & 68,8 & 100 & 13,3 & 86,7 & 100 & 66,7 & 33,3 & 100 & 11,1 & 88,9 & 100 \\
\hline \multirow{5}{*}{\multicolumn{4}{|c|}{ Níveis de acertos }} & \multicolumn{3}{|c|}{ Casos selecionados: } & \multicolumn{3}{|c|}{ Casos selecionados: } & Casos sel & cionado & & Casos s & ecionac & & Casos sel & cionad & \\
\hline & & & & Original & & $0 \%$ & Original & 74,2 & $0 \%$ & Original & 90,3 & $0 \%$ & Original & & & Original & & $0 \%$ \\
\hline & & & & Val. cruzada & & $0 \%$ & Val. cruzada & 61, & $0 \%$ & Val. cruzada & 80,0 & & Val. cruzada & & & Val. cruzada & & $0 \%$ \\
\hline & & & & Casos não s & elecion & dos: & Casos não s & leciona & dos: & Casos não & leciona & dos: & Casos não & elecior & los: & Casos não & lecion & dos: \\
\hline & & & & Original & 61, & $0 \%$ & Original & 74,2 & $0 \%$ & Original & 80,6 & $0 \%$ & Original & & $\%$ & Original & & $0 \%$ \\
\hline
\end{tabular}

Fonte: Dados da pesquisa realizada no SPSS (2016). 
Ao analisar essa tabela, identificam-se os resultados das classificações a partir das amostras. Os valores que constam nas diagonais (interseções Perd. $x$ Perd. e Venc. $x$ Venc.) correspondem ao número de empresas corretamente classificadas, tanto em unidades quanto em percentuais. Consequentemente, aqueles valores que estão fora dessas diagonais correspondem ao número de empresas incorretamente classificadas.

Nas colunas com o título "Total", identifica-se o número de empresas que efetivamente constam em cada grupo das amostras. Além disso, os valores nas linhas sob os títulos de Venc. (Vencedores) e Perd. (Perdedores) correspondem ao número de empresas classificadas àqueles grupos pelas funções discriminantes e, logo abaixo, seus respectivos percentuais de acertos e erros de classificações em cada grupo.

Ao final da Tabela 15, apresentam-se os níveis de acertos das classificações para os Casos Selecionados (Originais e Validação Cruzada), que correspondem às empresas da amostra de análise, e os casos não selecionados, que se relaciona à amostra de teste.

A validação cruzada é um passo essencial quando se objetiva conferir a razão de sucesso aos resultados, isto é, objetiva-se assegurar que os resultados da análise discriminante têm validade externa e interna. Desse modo, a validade pode ser conferida se a função discriminante classifica observações, em um nível aceitável, que não foram usadas no processo de estimação (HAIR Jr et al., 2005).

Se a amostra de validação é obtida através da amostra original, que são os resultados dos "Casos Selecionados" na Tabela 15, então essa avaliação estabelecerá a validade interna. Se uma outra amostra separada forma a amostra de validação, que são os "Casos não selecionados" na Tabela 15, então corresponderá a validação externa dos resultados discriminantes (HAIR Jr et al., 2005).

Vale ressaltar que a amostra denominada "Validação Cruzada", pertencente à amostra de análise, é o teste de Lachembruch, em que cada caso da amostra de desenvolvimento é retirado da amostra de validação cruzada e uma nova função é gerada e aplicada sobre ele para verificar a capacidade de classificação (MÁRIO, 2009).

A partir da Tabela 15, revela-se que as funções discriminantes estimadas para os cinco exercícios proporcionaram níveis de acertos de classificações iguais ou acima de 64,5\% ao avaliar os escores $Z_{\mathrm{i}}$ das empresas da amostra de análise, com destaque especial para os anos de 2012 e 2014, que atingiram 90,3\% e 93,3\% de acertos, respectivamente. Quanto à validação interna desses casos originais, observa-se que os níveis de acerto tiveram uma média acima de 53\%, com exceção do exercício de 2013, com $36,7 \%$. 
Por outro lado, ao se observarem os resultados da amostra de Teste (Casos não selecionados), percebe-se que os resultados das classificações das empresas apresentaram níveis de acertos iguais ou superiores a 61,3\% nos cinco exercícios. Esses resultados são considerados de maior importância para o estudo, em virtude da amostra de teste conter um grupo de empresas que não participaram da estimação da função discriminante, assim minimizando um viés ascendente que ocorre na precisão preditiva da função.

Em outras palavras, pode-se considerar que as funções discriminantes estimadas para cada exercício social têm capacidade para realizar, em um bom nível, a classificação de elementos externos a si, isto é, que não contribuíram para a sua composição (MÁRIO, 2009).

Comparando-se estes resultados com os achados da pesquisa de Tavares (2010), a qual foi realizada antes da adoção dos IFRS, verifica-se que somente em 2010 esta pesquisa obteve níveis de acertos próximos aqueles resultados encontrados por este autor, enquanto os resultados obtidos de 2011 a 2014 demonstraram níveis de acertos superiores.

Na pesquisa de Mota e Tavares (2015) verificou-se que os níveis de acertos no período pré-adoção dos IFRS (ano 2007) foi de 77,5\%, ao passo que após a adoção este percentual reduziu para 65\% (ano de 2011). Dessa forma, entende-se que os resultados desta pesquisa demonstram níveis de acertos superiores, uma vez que comparando-se o ano de 2011 obtivemos 74,2\% de acertos de classificações.

Outra medida do poder discriminatório da matriz de classificação é a estatística de chances $Q$ de Press, a qual compara o número de classificações corretas com o tamanho da amostra atual e o número de grupos. O valor calculado é, então, comparado com um valor crítico (o valor qui-quadrado para um grau de liberdade no nível de confiança desejado) (HAIR Jr et al., 2005).

A estatística Q é calculada pela seguinte fórmula:

$$
Q \text { de Press }=\frac{[N-(n K)]^{2}}{N(K-1)}
$$

Onde:

$\mathrm{N}=$ tamanho da amostra total;

$n$ = número de observações corretamente classificadas;

$\mathrm{K}=$ número de grupos. 
A partir dessa fórmula, os resultados da estatística $Q$ de Press estão dispostos de modo comparativo a validação da função discriminante, conforme Tabela 16 a seguir.

Tabela 16 - Resultados do teste $Q$ de Press

\begin{tabular}{c|c|c|c|c|c}
\hline Exercícios & $\mathbf{2 0 1 0}$ & $\mathbf{2 0 1 1}$ & $\mathbf{2 0 1 2}$ & $\mathbf{2 0 1 3}$ & $\mathbf{2 0 1 4}$ \\
\hline \multicolumn{6}{c}{ Validação Teórica (Q de Press): valor crítico a $0,05=3,84$} \\
\hline Casos selecionados - Originais & 2,61 & 7,26 & 20,16 & 9,32 & 22,53 \\
Casos selecionados - Validação Cruzada & 1,58 & 7,26 & 11,65 & 5,45 & 22,53 \\
Não selecionados - Originais & 0,13 & 1,58 & 10,80 & 2,13 & 14,23 \\
\hline \multicolumn{6}{c}{ Validação Prática: Igual ou maior que 64,5\% } \\
Casos selecionados - Originais & $64,5 \%$ & $74,2 \%$ & $90,3 \%$ & $77,4 \%$ & $93,3 \%$ \\
Casos selecionados - Validação Cruzada & $53,1 \%$ & $61,3 \%$ & $80,0 \%$ & $36,7 \%$ & $83,9 \%$ \\
Não selecionados - Originais & $61,3 \%$ & $74,2 \%$ & $80,6 \%$ & $71,0 \%$ & $93,3 \%$ \\
\hline
\end{tabular}

Fonte: Dados da pesquisa realizada no SPSS (2016).

Ao analisar os resultados do teste $Q$ de Press, observa-se que todas as amostras de análise seriam consideradas estatisticamente melhores do que as chances, com exceção apenas do ano de 2010, ao passo que as amostras de teste com resultados acima do valor crítico $(3,84)$ são apenas aquelas dos exercícios de 2012 e 2014.

Segundo Hair Jr et al. (2005), esse teste simples é sensível ao tamanho da amostra, em que amostras grandes são mais prováveis de apresentarem significância do que amostras pequenas da mesma taxa de classificação. Dessa forma, é necessário utilizar essa medida de modo complementar para não chegar a conclusões baseadas apenas nessa estatística.

Além do teste de chances, Mário (2009) ressalta outra medida de avaliação da função discriminante que serve para indicar a capacidade ou poder de explicação destas funções em nível estatístico, cujos dados são evidenciados na Tabela 17 a seguir.

Tabela 17 - Detalhamento da Avaliação da função discriminante

\begin{tabular}{c|c|c|c|c|c|c|c|c|c|c}
\hline & \multicolumn{4}{|c|}{ Valores próprios } & \multicolumn{5}{c}{ Lambda de Wilks } \\
\hline & Função & $\begin{array}{c}\text { Valor } \\
\text { próprio }\end{array}$ & $\begin{array}{c}\% \text { de } \\
\text { variância }\end{array}$ & $\begin{array}{c}\% \\
\text { cumulativa }\end{array}$ & $\begin{array}{c}\text { Correlação } \\
\text { canônica }\end{array}$ & $\begin{array}{c}\text { Teste de } \\
\text { funções }\end{array}$ & $\begin{array}{c}\text { Lambda de } \\
\text { Wilks }\end{array}$ & $\begin{array}{c}\text { Qui- } \\
\text { quadrado }\end{array}$ & df & Sig. \\
\hline $\mathbf{2 0 1 0}$ & 1 &, $403^{\text {a }}$ & 100 & 100 & 0,536 & 1 & 0,713 & 9,486 & 2 & 0,009 \\
\hline $\mathbf{2 0 1 1}$ & 1 &, $661^{\text {a }}$ & 100 & 100 & 0,631 & 1 & 0,602 & 14,214 & 2 & 0,001 \\
\hline $\mathbf{2 0 1 2}$ & 1 &, $951^{\text {a }}$ & 100 & 100 & 0,698 & 1 & 0,513 & 18,374 & 3 & 0,000 \\
\hline $\mathbf{2 0 1 3}$ & 1 &, $698^{\text {a }}$ & 100 & 100 & 0,641 & 1 & 0,589 & 14,552 & 3 & 0,002 \\
\hline $\mathbf{2 0 1 4}$ & 1 & $1,187^{\text {a }}$ & 100 & 100 & 0,737 & 1 & 0,457 & 21,125 & 2 & 0,000 \\
\hline
\end{tabular}

Fonte: Dados da pesquisa realizada no SPSS (2016). 
Observando a Tabela 17, verifica-se que a coluna denominada "Valor próprio" indica o grau de superioridade entre funções. Como esta pesquisa não utiliza modelos de múltiplas análises discriminantes (MDA), entende-se que uma única função de cada exercício social tem sua própria importância (MÁRIO, 2009).

O poder explicativo da função pode ser avaliado através dos resultados da estatística de Lambda de Wilks, cujo entendimento é que, quanto mais próximos de zero forem os resultados de Lambda de Wilks e do seu nível de significância, mais intensa será a diferença entre as médias dos grupos e, por conseguinte, indicará que a função tem alta capacidade de discriminar os elementos entre os grupos.

Nesse caso, pode-se afirmar estatisticamente que as funções discriminantes estimadas para os exercícios de 2010 a 2014 possuem capacidade ou poder discriminatório entre os grupos por apresentaram níveis de significância inferiores a 0,05 ou próximos a zero.

\subsection{INTERPRETAÇÃO DO MODELO ANÁLISE DISCRIMINANTE}

Segundo Mário (2009), a Análise Discriminante é uma técnica estatística que auxilia a identificar quais as variáveis que diferenciam os grupos e quantas dessas variáveis são necessárias para obter a melhor classificação dos indivíduos de uma determinada amostra.

Nesse tipo de análise, a variável dependente tem característica qualitativa (não métrica) e as variáveis independentes são métricas, de modo que, por meio de uma combinação linear entre esse conjunto de informações, obtido através das variáveis consideradas independentes, produzam o valor de uma variável dependente que possibilite discriminar melhor os grupos definidos.

$\mathrm{Na}$ presente pesquisa, admitem-se dois grupos de empresas: as empresas numeradas no grupo 0 são classificadas como "Vencedoras", que são aquelas que possuem maior crescimento de valor de mercado, e aquelas empresas do grupo 1 são classificadas como "Perdedoras", indicando aquelas de menor crescimento ou maior redução no valor de mercado (Vide Apêndice B). 
Quanto aos resultados obtidos com a análise discriminante, observe-se na Tabela 18, um breve resumo das variáveis preditoras e os níveis de acertos das classificações das empresas entre os grupos por cada exercício social:

\begin{tabular}{|c|c|c|c|}
\hline \multirow{2}{*}{ Exercício } & \multirow{2}{*}{ Variáveis } & \multicolumn{2}{|c|}{ Níveis de acertos } \\
\hline & & Amostra de Análise & Amostra de Teste \\
\hline \multirow{2}{*}{2010} & Crescimento das Vendas & \multirow{2}{*}{$64,5 \%$} & \multirow{2}{*}{$61,3 \%$} \\
\hline & Liquidez Geral & & \\
\hline \multirow{2}{*}{2011} & Margem Ebtida & \multirow{2}{*}{$74,2 \%$} & \multirow{2}{*}{$74,2 \%$} \\
\hline & Liquidez corrente & & \\
\hline \multirow{3}{*}{2012} & Q deTobin & \multirow{3}{*}{$90,3 \%$} & \multirow{3}{*}{$80,6 \%$} \\
\hline & Crescimento das Vendas & & \\
\hline & Giro do Ativo & & \\
\hline \multirow{3}{*}{2013} & PCCT & \multirow{3}{*}{$77,4 \%$} & \multirow{3}{*}{$71,0 \%$} \\
\hline & Crescimento das Vendas & & \\
\hline & ROE & & \\
\hline \multirow{2}{*}{2014} & Crescimento das Vendas & \multirow{2}{*}{$93,3 \%$} & \multirow{2}{*}{$93,3 \%$} \\
\hline & Book-to-market & & \\
\hline
\end{tabular}

Fonte: Dados da pesquisa.

Ao analisar a Tabela 18, observa-se que as variáveis selecionadas (Crescimento das Vendas, Liquidez Geral, Margem Ebtida, Liquidez Corrente, Q de Tobin, Giro do Ativo, PCCT, ROE e Book-to-Market) são medidas usuais utilizadas para sinalizar se uma empresa possui uma eficiente gestão de seus recursos a fim de produzir bons resultados em sua atividade operacional.

Com base nessas variáveis, pode-se observar que as classificações de empresas indicadas pela análise discriminante obtiveram níveis de acertos satisfatórios para todos os anos e em todas as subamostras, cujos resultados foram acima de $60 \%$ e chegaram até o nível de 93,3\% de acertos.

Além disso, com fins de responder a problemática deste trabalho, observa-se que houve uma evolução na capacidade preditiva a partir dos índices econômico-financeiros apenas nos exercícios de 2011, 2012 e 2014 quando se comparam seus resultados com os níveis de acertos obtidos no ano anterior. Ao passo que, no ano de 2013, houve uma diminuição na capacidade de discriminar as empresas em relação ao ano de 2012. 
Vale ressaltar que esses resultados estão baseados no grupo de empresas participantes do segmento de Governança Corporativa no período de 2010 a 2014, e, por isso, pode não se aplicar o mesmo entendimento para as demais empresas ou outros segmentos.

Assim, compreende-se que o modelo da análise discriminante dispõe de dados que permitem estabelecer classificações e indicações em seus resultados que determinada entidade em questão se assemelha mais com aquelas que se encontram em situação financeira superior do que com as que forneceram uma indicação negativa da questão financeira. 


\section{CONSIDERAÇÕES FINAIS}

Com o processo de convergência das normas brasileiras para as normas internacionais de contabilidade, advindo da promulgação das Leis $\mathrm{n}^{\circ} 11.638 / 2007$ e $\mathrm{n}^{\circ}$ 11.941/2009, e o surgimento das normas emitidas pelo Comitê de Pronunciamentos Contábeis (CPC), as demonstrações contábeis sofreram mudanças nas formas de reconhecer, mensurar e evidenciar ativos e passivos, e espera-se que as informações produzidas sejam relevantes, úteis e oportunas aos usuários da informação contábil.

O foco deste trabalho é analisar a capacidade preditiva das informações contábeis das companhias pertencentes ao segmento de Governança Corporativa na BM\&FBovespa. De forma que, a partir do estudo de Tavares (2010), buscou-se avaliar se a adoção das Normas Internacionais de Contabilidade pelas companhias abertas com ações listadas nos níveis de Governança Corporativa contribuiu para evolução da capacidade de discriminar entre alternativas de investimento, a partir dos índices econômico-financeiros.

Justifica-se a escolha das empresas do segmento de Governança Corporativa, porque, segundo Vieira et al. (2011), os investidores, credores e acionistas possuem maior disposição em aplicar seus recursos nas organizações que adotam as práticas de Governança Corporativa, a qual objetiva proteger seus direitos contra a expropriação dos seus controladores.

Para alcançar o objetivo proposto foram levantados e selecionados os índices econômico-financeiros mais utilizados pelas pesquisas científicas na área contábil durante os anos de 2010 a 2014. Segundo, levantou-se o valor dessas variáveis para cada empresa da amostra através do banco de dados da Bloomberg®. Por fim, aplicouse a técnica de análise discriminante aos dados anuais a fim de verificar o nível de acertos na previsão de melhores e piores alternativas de investimento, bem como de avaliar a evolução da capacidade preditiva nos índices econômico-financeiros durante os cinco analisados.

O primeiro resultado apontado após executar a análise discriminante é o resultado do teste de igualdade de médias dos grupos para cada exercício social, o qual revela os índices com maior poder de explicação através das estatísticas Lambda de Wilks (quanto maior a estatística da variável, melhor a discriminação dos grupos) e do teste $F$-Anova (quanto menor o nível de significância, isto é, menor que 0,05 , indicam diferença significante entre as médias do grupo). 
De todos os índices utilizados, no ano de 2010, foram considerados significativos apenas dois índices: $\mathrm{X}_{10}$ (Crescimento das vendas) e $\mathrm{X}_{13}$ (Liquidez Geral). No ano 2011, $\mathrm{X}_{14}$ (Margem Ebtida) e $\mathrm{X}_{5}$ (Liquidez Corrente), ao passo que, em 2012, foi selecionada novamente como significativa a variável $\mathrm{X}_{10}$ (Crescimento das Vendas), além das variáveis $\mathrm{X}_{6}$ (Q de Tobin) e $\mathrm{X}_{2}$ (Giro do Ativo). Em 2013, também foram três os índices significativos, incluindo novamente a variável $\mathrm{X}_{10}$ (Crescimento das Vendas) e as variáveis $\mathrm{X}_{3}(\mathrm{ROE})$ e $\mathrm{X}_{12}$ (PCCT). Por fim, no ano de 2014, consideraram-se significativas novamente a variável $\mathrm{X}_{10}$ (Crescimento das Vendas) e a variável $\mathrm{X}_{4}$ (Book-to-market).

Observa-se que todos estes índices econômico-financeiros com capacidade discriminatória entre os grupos são aqueles índices baseados em valores extraídos das demonstrações contábeis, com exceção dos índices Q de Tobin e Book-to-market que são baseados em dados do mercado acionário. Desse modo, apesar da evolução dos estudos e metodologias na criação/agrupamentos de índices, os índices selecionados neste estudo revelam a importância dos tradicionais índices econômico-financeiros extraídos das demonstrações contábeis para a tomada de decisão dos investidores e usuários quanto ao desempenho de empresas.

Com base nessas variáveis, foram realizadas previsões de alternativas de investimento, as quais apresentaram níveis de acerto significativamente melhores do que se a classificação nos grupos das empresas "vencedoras" e "perdedoras" fosse realizada ao acaso. Em 2010, os níveis de acertos de casos classificados corretamente nos grupos foram de 64,5\% para a amostra de análise e de 61,3\% para a amostra de teste. No ano de 2011, esses percentuais foram de 74,2\% para ambas as amostras; em 2012, a amostra de análise obteve um nível de acerto de 90,3\%, enquanto que a amostra de teste obteve $80,6 \%$ de acertos. No ano de 2013 , esses percentuais foram de $77,4 \%$ e $71 \%$ para as amostras de análise e de teste, respectivamente, e, no ano de 2014, os níveis de acertos foram de 93,3\% para ambas as amostras.

Observa-se, então, que as informações econômico-financeiras são significativamente relevantes para gerar análises capazes de discriminar empresas entre dois grupos: o das "vencedoras", que representa as empresas com melhor desempenho no período e indica ser a melhor alternativa de investimento, e o das "perdedoras", que abrange as empresas que não possuem boa situação financeira, e, consequentemente, podem não possuir capacidade suficiente para retornar o capital investido. 
Ao analisar os percentuais das classificações corretamente previstas nos cinco exercícios sociais $(64,5 \%, 74,2 \%, 90,3 \%, 77,4 \%$ e 93,3\%, respectivamente), observa-se uma evolução na capacidade preditiva a partir de índices econômico-financeiros. De modo que esses resultados indicam, primeiramente, que a adoção das normas internacionais de contabilidade contribuiu para uma melhor qualidade das informações contábeis divulgadas pelas empresas do mercado acionário, bem como entende-se que o uso dessa metodologia contribui para melhorar a tomada de decisão dos investidores.

Desse modo, acredita-se que os resultados desta pesquisa contribuem para a reflexão da importância e da potencialidade na capacidade preditiva das informações contábeis na escolha entre alternativas de investimento, bem como pode contribuir pra ampliar a aplicação de metodologias estatísticas nas análises de empresas.

Os resultados desta pesquisa limitam-se ao período, metodologia e amostra utilizada, de modo que as conclusões apresentadas devem ser consideradas com precaução e não se deve aplicar a outras empresas que extrapolem o universo pesquisado.

Devido às características intrínsecas e a amostra selecionada neste trabalho, recomenda-se que outras pesquisas sejam realizadas com a utilização de variáveis e empresas constantes por período, bem como a aplicação de outras metodologias estatísticas que testem a capacidade preditiva dos índices econômico-financeiros num grupo maior de empresas. 


\section{REFERÊNCIAS}

ALMEIDA, M. A. et al. Evolução da qualidade das práticas de governança corporativa: um estudo das empresas brasileiras de capital a aberto não listadas em bolsa. Revista de Administração Contemporânea. V. 14, N. 5, set./out. 2010.

ALVES, J. F. V. et al. Relação entre desempenho econômico e desempenho ambiental de empresas no Brasil e na Espanha. Revista Ambiente Contábil, V. 5, N. 2, jul./dez. 2013

ARTUSO, A. R.; CHAVES NETO, A. Análise discriminante e regressão logística reconhecimento de padrões para a seleção de portfólios no mercado acionário brasileiro. Revista da estatística UFOP, V. 3, 2014

ASSAF NETO, A. Estrutura e análise de balanços: um enfoque econômicofinanceiro. 9 ed. São Paulo: Atlas, 2010.

BARBOSA, G. C.; SILVA, C. A. T. Utilização dos indicadores contábeis no processo de avaliação de empresas: a percepção de professores de contabilidade e analistas de investimentos. Revista Ambiente Contábil, V. 6, N. 2, jul./dez. 2014.

BASTOS, E. C. Análise dos indicadores econômico-financeiros relevantes para avaliação das empresas. 2008. 151f. Dissertação (Mestrado em Ciências Contábeis) Universidade Regional de Blumenau, Blumenau, 2008.

BEZERRA, F. A.; CORRAR, L. J. Utilização da análise fatorial na identificação dos principais indicadores para avaliação do desempenho financeiro: uma aplicação nas empresas de seguros. Revista Contabilidade \& Finanças, V. 17, N. 42, set./dez. 2006.

BONFIM, E. T. Performance de empresas brasileiras: avaliação do efeito provocado por operações de fusões e aquisições. 2014. 99f. Dissertação (Mestrado em Ciências Contábeis) - Programa Multiinstitucional e Inter-regional de Pós-graduação em Ciências Contábeis UNB/UFPB/UFRN, João Pessoa, 2014.

BONFIM, P. R. C. M. et al. Utilização da análise multivariada na avaliação do desempenho econômico-financeiro de curto-prazo: uma aplicação no setor de distribuição de energia elétrica. Revista ADM.MADE, V. 15, N. 1, jan./abr. 2011.

BONFIM, P. R. C. M. et al. Indicadores financeiros e operacionais para a avaliação de desempenho de empresas do setor de petróleo e gás. Revista Contabilidade, Gestão e Governança, V. 16, N. 1, jan./abr. 2013.

BORTOLUZZI, S. C. et al. Avaliação de desempenho econômico-financeiro: uma proposta de integração de indicadores contábeis tradicionais por meio da Metodologia Multicritério de Apoio a Decisão Construtiva (MCDA-C). Revista Alvance, V. 18, N. 2, abr./jun. 2011.

BRASIL. Lei ${ }^{\circ}$ 6.404, de 15 de dezembro de 1976. Diário Oficial da República Federativa do Brasil, Brasília, 17 dez. 1976. 
Lei $\mathrm{n}^{\circ} 11.638$, de 28 de dezembro de 2007. Diário Oficial da República

Federativa do Brasil, Brasília, 28 dez. 2007.

Lei no 11.941, de 27 de maio de 2009. Diário Oficial da República

Federativa do Brasil, Brasília, 28 mai. 2009.

BRITO, R. P.; BRITO, L. A. L. Dynamics of competition and survival. Brazilian administration review, V. 11, N. 1, jan./mar. 2014

BRUNOZI JUNIOR, A. C. et al. Eficiência produtiva e análise econômica e financeira de usinas de cana-de-açúcar do estado de São Paulo. Revista Ambiente Contábil, V. 4, N.2, jul./dez. 2012

BUSHMAN, R. et al. What determines corporate transparency? Journal of Accounting Research, V. 42, N. 2, Maio 2004.

BUSHMAN, R.; SMITH, A. Financial accounting information and corporate governance. The Jornal of Accounting and Economics, N. 32, 2001.

BUSHMAN, R. M.; SMITH, A. J. Transparency, financial accounting information and corporate governance. Economic Policy Review, V. 9, N. 1, p. 65-87, 2003.

CALLADO, A. A. C. et al. O uso de indicadores de desempenho no âmbito das empresas do porto digital. IN: CONGRESSO USP DE CONTABILIDADE E CONTROLADORIA, 7., 2008. São Paulo. Anais. São Paulo: Congresso USP, 2008.

CAMARGOS, M. A.; BARBOSA, F. V. Análise do desempenho econômico-financeiro e da criação de sinergias em processos de fusões e aquisições do mercado brasileiro ocorridos entre 1995 e 1999. REGE - Revista de Gestão, V. 12, N. 2, p. 99-115, abr./jun.2005.

CARVALHO, V. G. et al. Divulgação da informação contábil: influência nas decisões de investimentos em ações. Registro Contábil - ReCont. V. 4, N. 2, 2013.

CATAPAN, A. et al. A relação entre a governança corporativa e o desempenho econômico-financeiro de empresas de capital aberto do Brasil. Revista Contabilidade, Gestão e Governança, V. 16, N. 2, p. 16-30, mai./ago, 2013.

CPC. Comitê de Pronunciamentos Contábeis. Pronunciamento Conceitual Básico. Estrutura conceitual para a elaboração e apresentação das demonstrações contábeis CPC 00-R1, 2011. Disponível em: 〈http://www.cpc.org.br〉. Acesso em: 08 out. 2014.

CRUZ, C. V. O. A. A relevância da informação contábil para os investidores sociais privados de entidades do terceiro setor no Brasil: uma investigação empírica. 2010. 165f. Tese (Doutorado em Ciências Contábeis) - Faculdade de Economia, Administração e Contabilidade da Universidade de São Paulo, São Paulo, 2010.

CRUZ, C. V. O. A.; LIMA, G. A. S. F. Reputação corporativa e nível de disclosure das empresas de capital aberto. Revista Universo Contábil, V. 6, N. 1, jan./mar. 2010. 
CUNHA, P. R. et al. Reflexos da Lei 11.638/07 nos indicadores contábeis das empresas têxteis listadas na BM\&FBovespa. Revista de educação e pesquisa em contabilidade - REPEC. V.7, N. 2, 2013.

DENIS, D. K.; MC CONNELL, J. International corporate governance. Journal of Financial and Quantitative Analysis. V. 38, N. 1, 2003.

FEA/USP. Contabilidade introdutória. Sérgio de Iudícibus (Coord.). 11 ed. São Paulo: Atlas, 2010.

FERREIRA, R. N. et al. Governança Corporativa, eficiência, produtividade e desempenho. RAM - Revista de Adm. Mackenzie, V. 14, N. 4, jul./ago. 2013.

FORTI, C. A. B. et al. Retenção de caixa, desempenho operacional e valor: um estudo no mercado de capitais brasileiro. Revista de contabilidade e organizações, V. 5, N. 13, set./dez. 2011.

GALLON, A. V. et al. Análise da relação entre evidenciação nos relatórios da administração e o nível de governança das empresas na Bovespa. RIC - Revista de Informação Contábil, V. 1, N. 2, out./dez. 2007.

GIRIOLI, L. S. Análise do uso de medidas de desempenho de empresas presentes na pesquisa em contabilidade no Brasil. 2010. 114f. Dissertação (Mestrado em Controladoria e Contabilidade) - Faculdade de Economia, Administração e Contabilidade de Ribeirão Preto, Universidade de São Paulo, São Paulo, 2010.

GONÇALVES, R. S. et al. Comportamento dos dez maiores bancos brasileiros durante a crise do subprime: uma análise por meio de indicadores contábeis. Revista de educação e pesquisa em contabilidade, V. 6, N. 2, abr./jun. 2012

GUTH, S. C.; FERNANDES, A. J.; PEREIRA, E. T. Construção de um indicador econômico e financeiro de grau de investimento corporativo: abordagem integrada.

Revista Universo Contábil, V. 7, N. 4, out./dez. 2011

HAIR JR, F. Jr. et al. Análise multivariada de dados. 5.ed. Porto Alegre: Bookman, 2005 .

HIJAZI, M. et al. A contribuição dos modelos de previsão de insolvência na prevenção de custos de falência: uma proposta de um novo modelo a partir de índices financeiros em empresas de capital aberto no Brasil. IN: Congresso Brasileiro de Custos, 22, Anais.... Foz do Iguaçu, 2015.

HOJI, M. Administração financeira: uma abordagem prática. 4 ed. São Paulo: Atlas, 2003.

IBGC - INSTITUTO BRASILEIRO DE GOVERNANÇA CORPORATIVA. Código das melhores práticas de governança corporativa. 4 ed. São Paulo: IBGC, 2009. 
IUDÍCIBUS, S. Análise de balanços: análise de liquidez e do endividamento, análise do giro, rentabilidade e alavancagem financeira, indicadores e análises espaciais (análise de tesouraria de Fleireut, EVA, DVA e EBTIDA). 10 ed. São Paulo: Atlas, 2010.

JENSEN, M.; MECKLING, W. Theory of the firm: managerial behavior, agency costs and ownership structure. Journal of Financial Economics, V. 3, N. 4, 1976.

KASSAI, S. Utilização da análise por envoltória de dados (DEA) na análise de demonstrações contábeis. 2002. 350f. Tese (Doutorado em Controladoria e Contabilidade) - Faculdade de Economia, Administração e Contabilidade da Universidade de São Paulo, São Paulo, 2002.

KIMURA, H. et al. Estudo da influência da governança corporativa e do ambiente institucional dos países na lucratividade das empresas. Revista de administração e contabilidade da Unisinos, V. 9, N. 2, abr./jun. 2012

LEAL, R. P. C. L.; SAITO, R. Finanças corporativas no Brasil. REA - Revista de Administração de Empresas. V. 2, N. 2, jul./dez. 2003.

LIEZ, T. J.; MARANVILLE, S. J. Ratio analysis featuring the Dupont Method: an overlooked topic in the finance module of small business management and entrepreneurship courses. Small Business Institute Journal, V. 1, 2008.

LYRA, R. L. W. C. Análise hierárquica dos indicadores contábeis sob a óptica do desempenho empresarial. 2008. 171f. Tese(Doutorado em Controladoria e Contabilidade) - Faculdade de Economia, Administração e Contabilidade da Universidade de São Paulo, São Paulo, 2008.

MACEDO, M. A. S.; CORRAR, L. J. Análise do desempenho contábil-financeiro de seguradoras no Brasil no ano de 2007: um estudo apoiado em Análise Hierárquica (AHP). Revista Contabilidade Vista \& Revista, V. 21, N.3, jul./set. 2010.

MARIO, P. C. Análise Discriminante. IN: CORRAR, L. J.; PAULO, E.; DIAS FILHO, J. M. Análise Multivariada: para os cursos de Administração, Ciências Contábeis e Economia. Atlas: São Paulo, 2009.

MARTINS, G. A.; THEÓPHILO, C. R. Metodologia da investigação científica para ciências sociais aplicadas. 2 ed. São Paulo: Atlas, 2009.

MARTINS, O. S. et al. Características e competências dos conselhos de administração de bancos brasileiros e sua relação com seu desempenho financeiro. Revista Universo Contábil, V. 8, N. 3, jul./set. 2012.

MATARAZZO, D. C. Análise financeira de balanços. 7. ed. São Paulo: Atlas, 2010.

MELO, E. B. et al. Avaliação econômico-financeira das companhias integrantes do IGC-BM\&Fbovespa sob a ótica da análise envoltória dos dados. Revista Ambiente Contábil, V. 6, N. 2, jul./dez. 2014. 
MINGOTI, S. A. Análise de dados através de métodos de estatística multivariada: uma abordagem aplicada. Belo Horizonte: Editora UFMG,2013.

MIRANDA, L. C.; SILVA, J. D. G. Medição de desempenho. IN: SHIMIDT, P. Controladoria agregando valor para a empresa. Porto Alegre: Bookman, 2002.

MOTA, R. H. G.; TAVARES, A. L. Classificação entre empresas vencedoras a perdedoras após a adoção das IFRS: um estudo em empresas não financeiras do setor regulado brasileiro com ações listadas na BM\&FBovespa. Revista Enfoque: reflexão contábil, V. 34, N. 2, mai./ago. 2015

MYER, J. N. Análise das demonstrações financeiras. Tradução de Danilo Ameixeiro Nogueira. São Paulo: Atlas, 1976.

NAVARRO, A. C. et al. Decisões de investimento e rentabilidade futura: estudo empírico com companhias abertas não financeiras. Revista de Contabilidade, Gestão e Governança, V. 16, N. 1, jan./abr. 2013

OLIVEIRA, K. P. S. et al. Governança corporativa, assimetria e qualidade da informação contábil no mercado de brasileiro de capitais. IN: Congresso USP Controladoria e Contabilidade, 14, Anais...São Paulo, 2014.

ORO, I. M. et al. Um estudo sobre a insolvência das empresas do setor têxtil em recuperação judicial utilizando a análise discriminante. IN: Congresso Brasileiro de Custos, 19, Anais...Bento Gonçalves, 2012.

PENMAN, S. H. An evaluation of accounting rate-of-return. Journal of Accounting, Auditing \& Finance, V. 6, N. 2, 1991.

REIS, E. M. et al. Investimento em meio ambiente e o desempenho econômico das empresas aderidas ao Índice Carbono Eficiente - ICO2. Revista de educação e pesquisa em contabilidade, V. 7, N. 4, out./dez. 2013.

REZENDE, I. C. C. et al. Análise da performance empresarial da Petrobras: um estudo sob o enfoque dos indicadores econômicos e financeiros. Revista Ambiente Contábil, V. 2, N.1, jan./jun. 2010

RIBEIRO, M. G. C. et al. Análise da relevância de indicadores financeiros e não financeiros na avaliação de desempenho organizacional: um estudo exploratório no setor brasileiro de distribuição de energia elétrica. Revista de Contabilidade e Organizações, V. 6, N. 15, mai./ago. 2012

SCHLEIFER, A.; VISHNY, R. W. A survey of corporate governance. The Journal of Finance, V. 52, N. 2, 1997.

SERRA, R. G. et al. Market crash, características das empresas e retorno -uma análise logística e discriminante. Revista de Contabilidade da UFBA, V. 8, N.1, jan./abr. 2014. 
SILVA, J. P. Análise financeira das empresas. 10. ed. São Paulo: Atlas, 2010.

SILVA, R. L. M.; NARDI, P. C. C. Demonstrações contábeis no Brasil após adoção do Cpc 13: reação do mercado de ações. Advances in Scientific and Applied Accounting, V. 7, p. 362-385, 2014.

SILVA, W. V. et al. A influência da adesão às práticas de Governança Corporativa no risco das ações de empresas de Capital Aberto. Revista Universo Contábil, V. 7, N. 4, out./dez. 2011.

SOARES, M. et al. O emprego da análise de balanços e métodos estatísticos na área pública: o ranking de gestão dos municípios catarinenses. Revista de Administração Pública, V. 45, N. 5, 2011.

SOUZA, A. A. et al. Indicadores Financeiros para hospitais. IN: SEMINÁRIOS EM ADMINISTRAÇÃO, 12, 2009, São Paulo. Anais... São Paulo: SEMEAD, 2009.

TAVARES, A. L. A eficiência da análise financeira fundamentalista na previsão de variações no valor da empresa. 2010. 182 f. Tese (Doutorado em Ciências Contábeis)

- Programa de Doutorado Multi-institucional e Inter-Regional de Pós-Graduação em Ciências Contábeis (UnB/UFPB/ UFRN), Natal, 2010.

TAVARES, A. L.; SILVA, C. A. T. A análise financeira fundamentalista na previsão de melhores e piores alternativas de investimento. Revista Universo Contábil, V. 8, N. 1, jan./mar. 2012.

TEIXEIRA, S. A. et al. Análise discriminante como preditiva de dificuldades financeirasem empresas brasileiras do mercado acionário. Revista Catarinense de Ciências Contábeis - CRCSC, V. 12, N. 36, ago./nov. 2013.

TONI, A.; TONCHIA, S. Performance measurement systems: models, characteristics and measures. International Journal of Operations e Producing Management, V. 21, N. 1-2, 2001.

VIEIRA, K. M. et al. A influência da governança corporativa no desempenho e na estrutura de capital das empresas listadas na Bovespa. Revista Universo Contábil, V. 7, N. 1, jan./mar. 2011.

YAMAMOTO, M. M.; SALOTTI, B. M. Informação contábil: Estudos sobre a sua divulgação no Mercado de Capitais. São Paulo: Atlas, 2006. 


\section{APÊNDICE A \\ LISTA DE ARTIGOS CONSULTADOS NESTA PESQUISA}

ALMEIDA-SANTOS, P. S. et al. Desempenho econômico e a responsabilidade social corporativa: uma contribuição para a análise da relação destas variáveis no caso das maiores companhias abertas Brasileiras. Revista Enfoque: reflexão contábil, V. 32, N. 3, jan./abr. 2013

ALVES, J. F. V. et al. Relação entre desempenho econômico e desempenho ambiental de empresas no Brasil e na Espanha. Revista Ambiente Contábil, V. 5, N. 2, jul./dez. 2013

ANDRADE, A. M. F.; GALINA, S. V. R. Efeitos da Internacionalização sobre o Desempenho de Multinacionais de Economias em Desenvolvimento. Revista de Administração Contemporânea, V. 17, N. 2, mar./abr. 2013

BACHMANN, R. K. B. et al. Reflexos do desempenho financeiro nas boas notícias: análise linguística em companhias brasileiras transparentes. Revista Contemporânea de contabilidade, V. 11, N. 22, jan./abr. 2014

BANDEIRA-DE-MELLO, R.; MARCON, R.; ALBERTON, A. Performance Effects of Stakeholder Interaction in Emerging Economies: Evidence from Brazil. Brazilian Administration Review, V. 8, N. 3, jul./set. 2011

BALL, Ray; BROWN, Philip. An empirical evaluation of accounting income numbers. Journal of Accounting Research. V. 6, N. 2, Autumn, 1968.

BONFIM, P. R. C. M.; MACEDO, M. A. S.; MARQUES, J. A. V. C. Indicadores financeiros e operacionais para a avaliação de desempenho de empresas do setor de petróleo e gás. Revista Contabilidade, Gestão e Governança, V. 16, N. 1, jan./abr. 2013

BORTOLUZZO, A. B. et al. Desempenho de fusões e aquisições cross border: análise empírica do caso brasileiro. Revista de Administração de Empresas, V. 54, N. 6, nov./dez. 2014

BRITO, R. P.; BRITO, L. A. L. Dynamics of competition and survival. Brazilian administration review, V. 11, N. 1, jan./mar. 2014

BRITO, R. P.; BRITO, L. A. L. Vantagem Competitiva, Criação de valor e seus efeitos sobre o Desempenho. Revista de Administração de Empresas, V. 52, N. 1, jan./fev. 2012

BRUNOZI JUNIOR, A. C. et al. Eficiência produtiva e análise econômica e financeira de usinas de cana-de-açúcar do estado de São Paulo. Revista Ambiente Contábil, V. 4, N.2, jul./dez. 2012 
CAIXE, D. F.; KRAUTER, E. The Relation between corporate governance and market value: mitigating endogeneity problems. Brazilian Business Review, V. 11, N. 1, jan./mar. 2014

CAMARGOS, M. A.; BARBOSA, F. V. Fusões e aquisições de empresas brasileiras: sinergias operacionais, gerenciais e rentabilidade. Revista Contabilidade Vista e Revista, V. 21, N. 1, jan./mar. 2010

CAMILO, S. P. O. et al. Conexões Políticas e Desempenho: um Estudo das Firmas Listadas na BM\&FBovespa. Revista de Administração Contemporânea, V. 16, N. 6, nov./dez. 2012

CARDOSO, V. I. C. et al. Reputação corporativa nas empresas brasileiras: uma questão relevante para o desempenho empresarial? Revista Contemporânea de contabilidade, V. 10, N. 21, set./dez. 2013

CARVALHO, F. L. et al. Identificação de indicadores contábeis relevantes para previsão e projeção de rentabilidade. Revista de educação e pesquisa em contabilidade, V. 4, N. 3, set./dez. 2010

CARVALHO, F. M.; KAYO, E. K.; MARTIN, D. M. L. Tangibilidade e Intangibilidade na Determinação do Desempenho Persistente de Firmas Brasileiras. Revista de Administração Contemporânea, V. 14, N. 5, set./out. 2010

CATAPAN; A.; COLAUTO, R. D.; BARROS, C. M. E. A relação entre a governança corporativa e o desempenho econômico-financeiro de empresas de capital aberto do Brasil. Revista Contabilidade, Gestão e Governança, V. 16, N. 2, p. 16-30, mai./ago, 2013.

CONCEIÇÃO, S. H. et al. Fatores determinantes no disclosure em Responsabilidade Social Corporativa (RSC): um estudo qualitativo e quantitativo com empresas listadas na Bovespa. Revista Gestão e Produção, V. 18, N. 3, 2011.

CUNHA, M. F.; MARTINS, E.; ASSAF NETO, A. A finalidade da avaliação de empresas, no Brasil, apresenta viés? Evidências empíricas sob o ponto de vista do desempenho econômico-financeiro. Revista Contabilidade Vista \& Revista, V. 23, N.3, jul./set. 2012.

CUNHA, P. R. et al. Reflexos da lei n. ${ }^{\circ}$ 11.638/07 nos indicadores contábeis das empresas têxteis listadas na BM\&FBovespa. Revista de educação e pesquisa em contabilidade, V. 7, N. 2, abr./jun. 2013

DAKESSIAN, L. C.; FELDMANN, P. R. Multilatinas and Value Creation from CrossBorder Acquisitions: An Event Study Approach. Brazilian Administration Review, V. 10, N. 4, out./dez. 2013

DUARTE, A. L. C. M. et al. Operational Practices and Financial Performance: an Empirical Analysis of Brazilian Manufacturing Companies. Brazilian Administration Review, V. 8, N. 4, out./dez. 2011 
FERREIRA, F. C. M.; GOLDSZMIDT, R. G. B.; CSILLAG, J. M. The Regional Concentration of Industries and the Performance of Firms: a Multilevel Approach. Brazilian Administration Review, V. 7, N. 4, out./dez. 2010

FERREIRA, R. V.; CHEROBIM, A. P. M. S. Impacto dos investimentos em TI no desempenho organizacional de empresas de panificação de minas gerais: estudo multicaso. Revista de administração e contabilidade da Unisinos, V. 9, N. 2, abr./jun. 2012

FORTI, C. A. B.; PEIXOTO, F. M.; FREITAS, K. S. Retenção de caixa, desempenho operacional e valor: um estudo nomercado de capitais brasileiro. Revista de contabilidade e organizações, V. 5, N. 13, set./dez. 2011

GALlON, A. V.; REINA, D. R. M.; ENSSLIN, S. R. O impacto da inovação no desempenho econômico-financeiro das MPEIs catarinenses beneficiadas pelo programa juro zero (FINEP). Revista de contabilidade e organizações, V. 4, N. 8, jan./abr. 2010

GONÇALVES, R. S. et al. Comportamento dos dez maiores bancos brasileiros durante a crise do subprime: uma análise por meio de indicadores contábeis. Revista de educação e pesquisa em contabilidade, V. 6, N. 2, abr./jun. 2012

GUTH, S. C.; FERNANDES, A. J.; PEREIRA, E. T. Construção de um indicador econômico e financeiro de grau de investimento corporativo: abordagem integrada. Revista Universo Contábil, V. 7, N. 4, out./dez. 2011

HALL, R. J.; BECK, F.; TOLEDO FILHO, J. R. Análise do impacto da crise subprime nas empresas do agronegócio brasileiro listadas na BM\&FBovespa. Revista custos e agronegócio, V. 9, N. 1, jan./mar. 2013

KIMURA, H. et al. Estudo da influência da governança corporativa e do ambiente institucional dos países na lucratividade das empresas. Revista de administração e contabilidade da Unisinos, V. 9, N. 2, abr./jun. 2012

KLAN, R. C.; BEUREN, I. M. Characteristics of companies that influence their voluntary disclosure of performance indicators. Brazilian Business Review, V. 8, N. 2, abr./jun. 2011

KOS, S. R.; ESPEJO, M. M. S. B.; RAIFUR, L. O conteúdo informacional do relatório da administração e o desempenho das empresas brasileiras do Ibovespa. Revista Universo Contábil, V. 10, N. 2, abr./jun. 2014

KRAUTER, E. Remuneração de executivos e desempenho financeiro: um estudo com empresas brasileiras. Revista de educação e pesquisa em contabilidade, V. 7, N. 3, jul./set. 2013

KRONBAUER, C. A. et al. Impacto do reconhecimento de ativos fiscais diferidos na estrutura financeira e no desempenho econômico de empresas brasileiras. Revista Contemporânea de contabilidade, V. 9, N. 17, jan./jun. 2012 
LAZZARINI, S. G.; BRITO, L. A. L.; CHADDAD, F. R. Conduits of Innovation or Imitation? Assessing the Effect of Alliances on the Persistence of Profits in U.S. Firms. Brazilian Administration Review, V. 10, N. 1, jan./mar. 2013

LEITÃO, C. R. S.; KOVACS, E. P. Impacto das fusões e aquisições no desempenho das empresas: um estudo no setor de papel e celulose. Revista custos e agronegócio, V. 10, N. 2, abr./jun. 2014

LUCA, M. M. M. et al. Intangible Assets and Superior and Sustained Performance of Innovative Brazilian Firms. Brazilian administration review, V. 11, N. 4, out./dez. 2014

MACEDO, M. A. S.; CAVALCANTE, G. T. Desempenho contábil-financeiro de seguradoras no Brasil: um estudo apoiado em análise envoltória de dados (DEA) para o ano de 2007. Revista Universo Contábil, V. 7, N. 2, abr./jun. 2011

MACEDO, M. A. S.; CORRAR, L. J. Análise do desempenho contábil-financeiro de seguradoras no Brasil no ano de 2007: um estudoapoiado em Análise Hierárquica (AHP). Revista Contabilidade Vista \& Revista, V. 21, N.3, jul./set. 2010.

MACEDO, M. A. S.; CORRAR, L. J.; SIQUEIRA, J. R. M. Análise comparativa do desempenho contábil-financeiro de empresas socioambientalmente responsáveis no Brasil. Revista de administração e contabilidade da Unisinos, V. 9, N. 1, jan./mar. 2012

MACHADO, M. A. V.; MACHADO, M. R. Responsabilidade social impacta o desempenho financeiro das empresas? Advances in Scientific and Applied Accounting, V. 4, N. 1, 2011

MAGRO, C. B. D. et al. Contabilidade rural: comparativo na rentabilidade das atividades leiteira e avícola.Revista custos e agronegócio, V. 9, N. 1, jan./mar. 2013

MARTINS, O. S. et al. Características e competências dos conselhos de administração de bancos brasileiros e sua relação com seu desempenho financeiro. Revista Universo Contábil, V. 8, N. 3, jul./set. 2012

MARTINS, O. S.; PAULO, E. Reflexo da adoção das IFRS na análise de desempenho das companhias de capital aberto no Brasil. Revista de contabilidade e organizações, V. 4, N. 9, mai./ago. 2010

MATOS, O. M. S. P.; GALDI, F. C. O impacto das transações com partes relacionadas na performance operacional das companhias listadas na BM\&Fbovespa. Revista Contabilidade Vista \& Revista, V. 25, N. 2, mai./ago. 2014

MAZZIONI, S. et al. A relação entre a intangibilidade e o desempenho econômico: estudo com empresas de capital aberto do Brasil, Rússia, Índia, China e África do Sul (BRICS). Advances in Scientific and Applied Accounting, V. 7, N. 1, 2014 
MELO, E. B.; BOENTE, D. R.; MÓL, A. R. L. Avaliação econômico-financeira das companhias integrantes do IGC-BM\&FBovespa sob a ótica da análise envoltória de dados. Revista Ambiente Contábil, V. 6, N. 2, jul./dez. 2014

MESQUITA, J. M. C.; MARTINS, H. C. Retail industry: seasonality in sales, and financial results. Brazilian Business Review, V. 8, N. 3, jul./set. 2011

MURCIA, F. C. S. et al. The Determinants of Credit Rating: Brazilian Evidence. Brazilian administration review, V. 11, N. 2, abr./jun. 2014

NASCIMENTO, C.; FRANCO, L. M. G.; CHEROBIM, A. P. M. S. Associação entre remuneração variável e indicadores financeiros: evidências do setor elétrico. Revista Universo Contábil, V. 8, N. 1, jan./mar. 2012

NASCIMENTO, E. M. et al. Ativos intangíveis: análise do impacto do grau de intangibilidade nos indicadores de desempenho empresarial. Revista Enfoque: reflexão contábil, V. 31, N. 1, jan./abr. 2012

NAVARRO, A. C. et al. Decisões de investimento e rentabilidade futura: estudo empírico com companhias abertas não financeiras. Revista de Contabilidade, Gestão e Governança, V. 16, N. 1, jan./abr. 2013

ORELLANO, V. I. F.; QUIOTA, S. Análise do retorno dos investimentos socioambientais das empresas brasileiras. Revista de Administração de Empresas, V. 51, N.5, set./out. 2011

PEIXOTO, F. M.; BUCCINI, A. R. A. Separação entre propriedade e controle e sua relação com desempenho e valor de empresas brasileiras: onde estamos? Revista de contabilidade e organizações, V. 17, N. 18, 2013

REIS, A. M.; TEIXEIRA, A. J. C. Utilização de artefatos de contabilidade gerencial nas sociedades cooperativas agropecuárias de minas gerais e sua relação com porte e desempenho financeiro. Revista de educação e pesquisa em contabilidade, V. 7, N. 4, out./dez. 2013

REIS, E. M.;MOREIRA, M. A.; FRANÇA, R. S. Investimento em meio ambiente e o desempenho econômico das empresas aderidas ao índice carbono eficiente - $\mathrm{ICO}^{2}$. Revista de educação e pesquisa em contabilidade, V. 7, N. 4, out./dez. 2013

REZENDE, I. C. C.et al. Análise da performance empresarial da Petrobras: um estudo sob o enfoque dos indicadores econômicos e financeiros. Revista Ambiente Contábil, V. 2, N.1, jan./jun. 2010

RIBEIRO, M. G. C.; MACAEDO, M. A. S.; MARQUES, J. A. C. V. Análise da relevância de indicadores financeiros e não financeiros na avaliação de desempenho organizacional: um estudo exploratório no setor brasileiro de distribuição de energia elétrica. Revista de Contabilidade e Organizações, V. 6, N. 15, mai./ago. 2012

RODRIGUES PRIMO, U. et ai. Determinantes da rentabilidade bancária no Brasil. Revista de administração e contabilidade da Unisinos, V. 10, N. 4, out./dez. 2013 
ROSA, M. S. S.; LUSTOSA, P. R. B. Mercado e desempenho operacional contábil de longo prazo. Revista de administração e contabilidade da Unisinos, V. 11, N. 1, jan./mar. 2014

ROSSONI, L.; MACHADO-DA-SILVA, C. L. Legitimidade, governança corporativa e desempenho: análise das empresas da BM\&FBOVESPA. Revista de Administração de Empresas, V. 53, N. 3, mai./jun. 2013

RUFINO, M. A. et al. Sustentabilidade e performance dos indicadores de rentabilidade e lucratividade: um estudo comparativo entre os bancos integrantes e não integrantes do ISE da BM\&FBovespa. Revista Ambiente Contábil, V. 6, N. 1, jan./jun. 2014

SANTOS, D. F. L.; BASSO, L. F. C.; KIMURA, H. O recurso inovação e o desempenho financeiro da indústria brasileira. Revista de administração e contabilidade da Unisinos, V. 11, N. 3, jul./set. 2014

SANTOS, M. R.; CODA, R.; MAZZALI, L. Clima organizacional e desempenho financeiro. Revista Universo Contábil, V. 6, N. 2, abr./jun. 2010

SILVA, A. L. C.; CHIEN, A. C. Y. Remuneração Executiva, Valor e Desempenho das Empresas Brasileiras Listadas. Revista Brasileira de Finanças, V. 11, N. 4, 2013

SILVA, J. I. et al. Capital humano e o desempenho econômico-financeiro de empresas brasileiras do setor elétrico. Advances in Scientific and Applied Accounting, V. 6, N. 1,2013

SILVA, R. L. M. et al. Factors affecting stock liquidity: corporate governance, ADRs and economic crisis. Brazilian Business Review, V. 11, N. 1, jan./mar. 2014

SOUZA, I. B.; KLOECKNER, G. O. A governança corporativa influencia a eficiência das empresas brasileiras? Revista de Contabilidade \& Finanças, V. 25, N. 65, mai./ago. 2014

STARLING, R. N.; PORTO, R. B. Dinâmicas do Desempenho Financeiro, da Mudança Estratégica e da Concentração Industrial em Empresas Brasileiras. Revista de Administração Contemporânea, V. 18, N. 4, jul./ago. 2014

TAVARES, A. L.; SILVA, C. A. T. A análise financeira fundamentalista na previsão de melhores e piores alternativas de investimento. Revista Universo Contábil, V. 8, N. 1, jan./mar. 2012

TESSAROLO, I. F.; PAGLIARUSSI, M. S.; LUZ, A. T. M. The justification of organizational performance in annual report narratives. Brazilian Administration Review, V. 7, N. 2, abr./jun. 2010

VELOSO, G. G.; MALIK, A. M. Análise do desempenho econômico-financeiro de empresas de saúde. Revista de Administração de Empresas Eletrônica, V. 9, N. 1, jan./jun. 2010 
VIEIRA, K. M. et al. A influência da governança corporativa no desempenho e na estrutura de capital das empresas listadas na Bovespa. Revista Universo Contábil, V. 7, N. 1, jan./mar. 2011. 


\section{APÊNDICE B}

\section{Classificação real das empresas entre "Vencedoras" e "Perdedoras" por amostra}

Tabela A1 - Empresas da amostra no exercício de 2010

\begin{tabular}{|c|c|c|c|c|}
\hline \multirow{2}{*}{ Nome das empresas } & \multicolumn{3}{|c|}{ Valor de Mercado } & \multirow{2}{*}{ Classificação real } \\
\hline & 2009 & 2010 & \% Variação & \\
\hline Cia Hering & $1.560,60$ & $4.331,59$ & $177,56 \%$ & Vencedora \\
\hline Marisa Lojas S.A. & $1.920,64$ & $4.675,45$ & $143,43 \%$ & Vencedora \\
\hline Terios Internacional & $5.037,77$ & $11.181,11$ & $121,95 \%$ & Vencedora \\
\hline Brazil Hospitality Group & 329,47 & 720,89 & $118,80 \%$ & Vencedora \\
\hline Kroton Educacional S.A. & 710,17 & $1.486,10$ & $109,26 \%$ & Vencedora \\
\hline Eternit S.A. & 504,21 & $1.016,94$ & $101,69 \%$ & Vencedora \\
\hline Cosan S.A. Indústria e Comércio & $6.811,36$ & $13.723,07$ & $101,47 \%$ & Vencedora \\
\hline Pdg Realty S.A. Empreend.eParticipações & $8.179,85$ & $15.566,97$ & $90,31 \%$ & Vencedora \\
\hline Odontoprev S.A. & $2.295,09$ & $4.311,78$ & $87,87 \%$ & Vencedora \\
\hline Lps Brasil - Consultoria de Imóveis S.A. & $1.060,32$ & $1.946,97$ & $83,62 \%$ & Vencedora \\
\hline Trisul S.A. & 788,51 & $1.433,16$ & $81,75 \%$ & Vencedora \\
\hline Braskem S.A. & $13.469,39$ & $24.082,45$ & $78,79 \%$ & Vencedora \\
\hline Alpargatas S.A. & $1.941,32$ & $3.437,73$ & $77,08 \%$ & Vencedora \\
\hline Helbor Empreendimentos S.A. & 938,16 & $1.639,81$ & $74,79 \%$ & Vencedora \\
\hline Vanguarda Agro S.A. & 753,26 & $1.247,78$ & $65,65 \%$ & Vencedora \\
\hline Ez Tec Empreend. eParticipações S.A. & $1.168,59$ & $1.922,42$ & $64,51 \%$ & Vencedora \\
\hline Marcopolo S.A. & $2.079,73$ & $3.391,32$ & $63,07 \%$ & Vencedora \\
\hline Tegma GestãoLogística S.A. & $1.042,79$ & $1.691,16$ & $62,18 \%$ & Vencedora \\
\hline Iochpe Maxion S.A. & $1.678,16$ & $2.694,36$ & $60,55 \%$ & Vencedora \\
\hline Fleury S.A. & $1.924,53$ & $3.046,06$ & $58,28 \%$ & Vencedora \\
\hline Tpi - Triunfo Particip. eInvest. S.A. & $1.284,68$ & $1.989,25$ & $54,84 \%$ & Vencedora \\
\hline Arteris S.A. & $3.688,67$ & $5.655,73$ & $53,33 \%$ & Vencedora \\
\hline Raia Drogasil S.A. & $1.556,10$ & $2.384,17$ & $53,21 \%$ & Vencedora \\
\hline Diagnósticosda América S.A. & $3.627,05$ & $5.478,72$ & $51,05 \%$ & Vencedora \\
\hline Log-In Logística Intermodal S.A. & 816,46 & $1.231,39$ & $50,82 \%$ & Vencedora \\
\hline Brasil Brokers Participações S.A. & 999,05 & $1.505,83$ & $50,73 \%$ & Vencedora \\
\hline Tempo Participações S.A. & 397,41 & 597,71 & $50,40 \%$ & Vencedora \\
\hline Fras-Le S.A. & 297,35 & 440,33 & $48,08 \%$ & Vencedora \\
\hline Direcional Engenharia S.A. & $1.349,77$ & $1.945,56$ & $44,14 \%$ & Vencedora \\
\hline Totvs S.A. & $3.884,92$ & $5.458,29$ & $40,50 \%$ & Vencedora \\
\hline Eucatex S.A. Indústria e Comércio & 583,56 & 818,84 & $40,32 \%$ & Vencedora \\
\hline Lojas Renner S.A. & $4.795,48$ & $6.532,66$ & $36,23 \%$ & Vencedora \\
\hline Metalfrio Solutions S.A. & 529,00 & 715,45 & $35,24 \%$ & Vencedora \\
\hline
\end{tabular}


(Conclui)

\begin{tabular}{|c|c|c|c|c|}
\hline \multirow{2}{*}{ Nome das empresas } & \multicolumn{3}{|c|}{ Valor de Mercado } & \multirow{2}{*}{$\begin{array}{c}\text { Classificação } \\
\text { real }\end{array}$} \\
\hline & 2009 & 2010 & \% Variação & \\
\hline $\begin{array}{l}\text { Cia Providência Indústria } \\
\text { eComércio }\end{array}$ & 789,51 & 818,14 & $3,63 \%$ & Perdedora \\
\hline $\begin{array}{l}\text { Randon S.A. Implementos e } \\
\text { Participações }\end{array}$ & $2.724,71$ & $2.805,29$ & $2,96 \%$ & Perdedora \\
\hline Light S.A. & $6.928,63$ & $7.133,41$ & $2,96 \%$ & Perdedora \\
\hline Klabin S.A. & $7.606,28$ & $7.809,20$ & $2,67 \%$ & Perdedora \\
\hline Cia Paranaense de Energia - Copel & $10.112,89$ & $10.368,76$ & $2,53 \%$ & Perdedora \\
\hline Bematech S.A. & 381,85 & 389,87 & $2,10 \%$ & Perdedora \\
\hline $\begin{array}{l}\text { Cia Saneamento de Minas Gerais- } \\
\text { Copasa Mg }\end{array}$ & $4.981,92$ & $4.990,31$ & $0,17 \%$ & Perdedora \\
\hline Equatorial Energia S.A. & $2.664,71$ & $2.657,98$ & $-0,25 \%$ & Perdedora \\
\hline $\begin{array}{l}\text { Cyrela Brazil Realty } \\
\text { S.A.Empreend.ePart. }\end{array}$ & $13.011,02$ & $12.681,15$ & $-2,54 \%$ & Perdedora \\
\hline Jbs S.A. & $36.119,53$ & $33.936,37$ & $-6,04 \%$ & Perdedora \\
\hline $\begin{array}{l}\text { Usinas Sid de Minas Gerais S.A.- } \\
\text { Usiminas }\end{array}$ & $27.534,57$ & $25.847,07$ & $-6,13 \%$ & Perdedora \\
\hline $\begin{array}{l}\text { M.Dias Branco S.A. Ind. Com.de } \\
\text { Alimentos }\end{array}$ & $4.912,80$ & $4.602,43$ & $-6,32 \%$ & Perdedora \\
\hline $\begin{array}{l}\text { Profarma Distrib. } \\
\text { Prod.Farmacêuticos S.A. }\end{array}$ & 662,58 & 619,63 & $-6,48 \%$ & Perdedora \\
\hline $\begin{array}{l}\text { Eletropaulo Metrop. Elet. São } \\
\text { Paulo S.A. }\end{array}$ & $6.927,04$ & $6.387,69$ & $-7,79 \%$ & Perdedora \\
\hline Metalúrgica Gerdau S.A. & $37.940,12$ & $34.938,86$ & $-7,91 \%$ & Perdedora \\
\hline Paranapanema S.A. & $1.945,55$ & $1.778,83$ & $-8,57 \%$ & Perdedora \\
\hline Jhsf Participações S.A. & $1.656,88$ & $1.505,77$ & $-9,12 \%$ & Perdedora \\
\hline Suzano Papel eCelulose S.A. & $10.394,32$ & $9.302,68$ & $-10,50 \%$ & Perdedora \\
\hline Gerdau S.A. & $54.644,82$ & $47.284,85$ & $-13,47 \%$ & Perdedora \\
\hline Grendene S.A. & $2.321,38$ & $1.950,59$ & $-15,97 \%$ & Perdedora \\
\hline Ideiasnet S.A. & 637,76 & 528,44 & $-17,14 \%$ & Perdedora \\
\hline Fibria Celulose S.A. & $25.513,90$ & $20.909,92$ & $-18,04 \%$ & Perdedora \\
\hline Centrais Elet Bras S.A. - Eletrobras & $55.057,87$ & $44.326,70$ & $-19,49 \%$ & Perdedora \\
\hline B2w - Companhia Digital & $6.076,58$ & $4.746,25$ & $-21,89 \%$ & Perdedora \\
\hline Magnesita Refratários S.A. & $5.186,57$ & $3.937,17$ & $-24,09 \%$ & Perdedora \\
\hline Csu Cardsystem S.A. & 461,28 & 346,77 & $-24,82 \%$ & Perdedora \\
\hline Saraiva S.A. Livreiros Editores & $2.058,67$ & $1.424,24$ & $-30,82 \%$ & Perdedora \\
\hline Hypermarcas S.A. & $20.952,91$ & $14.103,97$ & $-32,69 \%$ & Perdedora \\
\hline Brf S.A. & $43.613,36$ & $27.490,46$ & $-36,97 \%$ & Perdedora \\
\hline Rossi Residencial S.A. & $8.343,29$ & $5.075,22$ & $-39,17 \%$ & Perdedora \\
\hline Positivo Informática S.A. & $1.981,65$ & $1.154,92$ & $-41,72 \%$ & Perdedora \\
\hline Prumo Logística S.A. & $6.865,97$ & $3.551,37$ & $-48,28 \%$ & Perdedora \\
\hline All America Latina Logística S.A. & $59.114,86$ & $15.371,85$ & $-74,00 \%$ & Perdedora \\
\hline
\end{tabular}

Fonte: Elaborada pela autora 
Tabela A2 - Empresas da amostra no exercício de 2011

\begin{tabular}{|c|c|c|c|c|}
\hline \multirow{2}{*}{ Nome das empresas } & \multicolumn{3}{|c|}{ Valor de Mercado } & \multirow{2}{*}{$\begin{array}{c}\text { Classificação } \\
\text { real }\end{array}$} \\
\hline & 2010 & 2011 & \% Variação & \\
\hline Jhsf Participações S.A. & $1.505,77$ & $2.779,20$ & $84,570 \%$ & Vencedora \\
\hline Raia Drogasil S.A. & $2.384,17$ & $4.107,45$ & $72,280 \%$ & Vencedora \\
\hline Cpfl Energia S.A. & $27.692,36$ & $37.274,19$ & $34,601 \%$ & Vencedora \\
\hline Brf S.A. & $27.490,46$ & $36.865,71$ & $34,104 \%$ & Vencedora \\
\hline Kroton Educacional S.A. & $1.486,10$ & $1.976,44$ & $32,995 \%$ & Vencedora \\
\hline Light S.A. & $7.133,41$ & $9.254,76$ & $29,738 \%$ & Vencedora \\
\hline $\begin{array}{l}\text { Cia Energéticade Minas Gerais - } \\
\text { Cemig }\end{array}$ & $24.079,01$ & $31.179,58$ & $29,489 \%$ & Vencedora \\
\hline São Martinho S.A. & $2.604,61$ & $3.368,77$ & $29,339 \%$ & Vencedora \\
\hline $\begin{array}{l}\text { M.Dias Branco S.A. Ind. Com.de } \\
\text { Alimentos }\end{array}$ & $4.602,43$ & $5.879,98$ & $27,758 \%$ & Vencedora \\
\hline $\begin{array}{l}\text { Cia Saneamento de Minas } \\
\text { Gerais-Copasa Mg }\end{array}$ & $4.990,31$ & $6.068,43$ & $21,604 \%$ & Vencedora \\
\hline Cosan S.A. Indústria e Comércio & $13.723,07$ & $16.582,22$ & $20,835 \%$ & Vencedora \\
\hline $\begin{array}{l}\text { Centrais Elet Bras S.A. - } \\
\text { Eletrobras }\end{array}$ & $44.326,70$ & $53.230,02$ & $20,086 \%$ & Vencedora \\
\hline Helbor Empreendimentos S.A. & $1.639,81$ & $1.949,97$ & $18,914 \%$ & Vencedora \\
\hline Cia Hering & $4.331,59$ & $5.139,08$ & $18,642 \%$ & Vencedora \\
\hline $\begin{array}{l}\text { Cteep - Cia Transmissão Energia } \\
\text { Elétrica Paulista }\end{array}$ & $9.739,03$ & $11.416,91$ & $17,228 \%$ & Vencedora \\
\hline Brazil Hospitality Group & 720,89 & 837,18 & $16,133 \%$ & Vencedora \\
\hline $\begin{array}{l}\text { Valid Soluções eServ. Seg. } \\
\text { Meios Pag. Ident. S.A. }\end{array}$ & $1.086,40$ & $1.248,50$ & $14,921 \%$ & Vencedora \\
\hline $\begin{array}{l}\text { Cia Saneamento Básico Est São } \\
\text { Paulo }\end{array}$ & $15.979,00$ & $18.300,61$ & $14,529 \%$ & Vencedora \\
\hline $\begin{array}{l}\text { Cia Saneamento Básico Est.São } \\
\text { Paulo }\end{array}$ & $9.771,59$ & $11.154,99$ & $14,157 \%$ & Vencedora \\
\hline Klabin S.A. & $7.809,20$ & $8.904,41$ & $14,025 \%$ & Vencedora \\
\hline Alpargatas S.A. & $3.437,73$ & $3.897,03$ & $13,361 \%$ & Vencedora \\
\hline $\begin{array}{l}\text { Tpi - Triunfo Particip. eInvest. } \\
\text { S.A. }\end{array}$ & $1.989,25$ & $2.251,35$ & $13,176 \%$ & Vencedora \\
\hline Fleury S.A. & $3.046,06$ & $3.446,25$ & $13,138 \%$ & Vencedora \\
\hline $\begin{array}{l}\text { Eletropaulo Metrop. Elet. São } \\
\text { Paulo S.A. }\end{array}$ & $6.387,69$ & $7.213,57$ & $12,929 \%$ & Vencedora \\
\hline Tegma GestãoLogística S.A. & $1.691,16$ & $1.907,84$ & $12,812 \%$ & Vencedora \\
\hline $\begin{array}{l}\text { Ez Tec Empreend. e } \\
\text { Participações S.A. }\end{array}$ & $1.922,42$ & $2.168,39$ & $12,794 \%$ & Vencedora \\
\hline Ccr S.A. & $24.889,46$ & $27.768,23$ & $11,566 \%$ & Vencedora \\
\hline Edp - Energias do Brasil S.A. & $10.296,60$ & $11.239,13$ & $9,154 \%$ & Vencedora \\
\hline Tecnisa S.A. & $2.777,42$ & $3.023,02$ & $8,843 \%$ & Vencedora \\
\hline Iochpe Maxion S.A. & $2.694,36$ & $2.908,28$ & $7,939 \%$ & Vencedora \\
\hline Santos Brasil Participações S.A. & $3.374,56$ & $3.636,55$ & $7,764 \%$ & Vencedora \\
\hline Cia Brasileira de Distribuição & $24.418,32$ & $26.280,43$ & $7,626 \%$ & Vencedora \\
\hline Arteris S.A. & $5.655,73$ & $5.999,04$ & $6,070 \%$ & Vencedora \\
\hline
\end{tabular}


(Conclui)

\begin{tabular}{|c|c|c|c|c|}
\hline \multirow{2}{*}{ Nome das empresas } & \multicolumn{3}{|c|}{ Valor de Mercado } & \multirow{2}{*}{$\begin{array}{l}\text { Classificação } \\
\text { real }\end{array}$} \\
\hline & 2010 & 2011 & \% Variação & \\
\hline Prumo Logística S.A. & $3.551,37$ & $2.864,50$ & $-19,341 \%$ & Perdedora \\
\hline Natura Cosméticos S.A. & $20.680,14$ & $16.198,24$ & $-21,672 \%$ & Perdedora \\
\hline $\begin{array}{l}\text { Profarma Distrib. } \\
\text { Prod.Farmacêuticos S.A. }\end{array}$ & 619,63 & 485,04 & $-21,720 \%$ & Perdedora \\
\hline Trisul S.A. & $1.433,16$ & $1.116,30$ & $-22,109 \%$ & Perdedora \\
\hline $\begin{array}{l}\text { Cyrela Brazil Realty } \\
\text { S.A.Empreend ePart. }\end{array}$ & $12.681,15$ & $9.826,42$ & $-22,512 \%$ & Perdedora \\
\hline Grendene S.A. & $1.950,59$ & $1.508,02$ & $-22,689 \%$ & Perdedora \\
\hline Eternit S.A. & $1.016,94$ & 775,83 & $-23,710 \%$ & Perdedora \\
\hline EstácioParticipações S.A. & $2.059,14$ & $1.564,41$ & $-24,026 \%$ & Perdedora \\
\hline Fibria Celulose S.A. & $20.909,92$ & $15.783,19$ & $-24,518 \%$ & Perdedora \\
\hline Vale S.A. & $320.859,44$ & $240.772,26$ & $-24,960 \%$ & Perdedora \\
\hline $\begin{array}{l}\text { Centrais Elet de Santa Catarina } \\
\text { S.A. }\end{array}$ & $1.570,54$ & $1.177,96$ & $-24,997 \%$ & Perdedora \\
\hline $\begin{array}{l}\text { Pdg Realty S.A. Empreend.e } \\
\text { Participações }\end{array}$ & $15.566,97$ & $11.671,54$ & $-25,024 \%$ & Perdedora \\
\hline Gerdau S.A. & $47.284,85$ & $35.348,64$ & $-25,243 \%$ & Perdedora \\
\hline Marisa Lojas S.A & $4.675,45$ & $3.492,95$ & $-25,292 \%$ & Perdedora \\
\hline $\begin{array}{l}\text { Rodobens NegóciosImobiliários } \\
\text { S.A }\end{array}$ & $1.513,75$ & $1.112,17$ & $-26,528 \%$ & Perdedora \\
\hline $\begin{array}{l}\text { All America Latina Logística } \\
\text { S.A. }\end{array}$ & $15.371,85$ & $11.197,95$ & $-27,153 \%$ & Perdedora \\
\hline Indústrias Romi S.A. & $1.834,45$ & $1.329,59$ & $-27,521 \%$ & Perdedora \\
\hline Tempo Participações S.A. & 597,71 & 432,37 & $-27,663 \%$ & Perdedora \\
\hline Csu Cardsystem S.A. & 346,77 & 249,99 & $-27,910 \%$ & Perdedora \\
\hline $\begin{array}{l}\text { Lps Brasil - Consultoria de } \\
\text { Imóveis S.A. }\end{array}$ & $1.946,97$ & $1.335,44$ & $-31,409 \%$ & Perdedora \\
\hline Duratex S.A. & $9.150,49$ & $6.082,39$ & $-33,529 \%$ & Perdedora \\
\hline Magnesita Refratários S.A. & $3.937,17$ & $2.612,98$ & $-33,633 \%$ & Perdedora \\
\hline Positivo Informática S.A. & $1.154,92$ & 745,65 & $-35,437 \%$ & Perdedora \\
\hline Gafisa S.A. & $7.338,60$ & $4.648,55$ & $-36,656 \%$ & Perdedora \\
\hline Saraiva S.A. Livreiros Editores & $1.424,24$ & 866,70 & $-39,146 \%$ & Perdedora \\
\hline Hypermarcas S.A. & $14.103,97$ & $8.058,15$ & $-42,866 \%$ & Perdedora \\
\hline B2w - Companhia Digital & $4.746,25$ & $2.610,83$ & $-44,992 \%$ & Perdedora \\
\hline Metalfrio Solutions S.A. & 715,45 & 386,15 & $-46,027 \%$ & Perdedora \\
\hline Brasil Brokers Participações S.A. & $1.505,83$ & 757,36 & $-49,704 \%$ & Perdedora \\
\hline Paranapanema S.A. & $1.778,83$ & 868,57 & $-51,172 \%$ & Perdedora \\
\hline Terios Internacional & $11.181,11$ & $5.074,50$ & $-54,615 \%$ & Perdedora \\
\hline Bematech S.A. & 389,87 & 148,74 & $-61,849 \%$ & Perdedora \\
\hline Fertilizantes Heringer S.A. & $1.055,81$ & 302,65 & $-71,334 \%$ & Perdedora \\
\hline
\end{tabular}

Fonte: Elaborada pela autora. 
Tabela A3 - Empresas da amostra no exercício de 2012

\begin{tabular}{|c|c|c|c|c|}
\hline \multirow{2}{*}{ Nome das empresas } & \multicolumn{3}{|c|}{ Valor de Mercado } & \multirow{2}{*}{$\begin{array}{c}\text { Classificação } \\
\text { real }\end{array}$} \\
\hline & 2011 & 2012 & \% Variação & \\
\hline Kroton Educacional S.A. & $1.976,44$ & $15.843,41$ & $701,61 \%$ & Vencedora \\
\hline Fertilizantes Heringer S.A. & 302,65 & $1.265,93$ & $318,28 \%$ & Vencedora \\
\hline Grendene S.A. & $1.508,02$ & $4.224,16$ & $180,11 \%$ & Vencedora \\
\hline EstácioParticipações S.A. & $1.564,41$ & $3.565,30$ & $127,90 \%$ & Vencedora \\
\hline $\begin{array}{l}\text { Valid Soluções eServ. Seg. } \\
\text { Meios Pag. Ident. S.A. }\end{array}$ & $1.248,50$ & $2.813,37$ & $125,34 \%$ & Vencedora \\
\hline Equatorial Energia S.A. & $2.404,90$ & $5.171,63$ & $115,05 \%$ & Vencedora \\
\hline Portobello S.A. & 389,61 & 818,42 & $110,06 \%$ & Vencedora \\
\hline Paranapanema S.A. & 868,57 & $1.753,40$ & $101,87 \%$ & Vencedora \\
\hline Marisa Lojas S.A & $3.492,95$ & $6.516,03$ & $86,55 \%$ & Vencedora \\
\hline Raia Drogasil S.A. & $4.107,45$ & $7.647,21$ & $86,18 \%$ & Vencedora \\
\hline $\begin{array}{l}\text { Helbor Empreendimentos } \\
\text { S.A. }\end{array}$ & $1.949,97$ & $3.589,79$ & $84,10 \%$ & Vencedora \\
\hline Fras-Le S.A. & 377,59 & 686,76 & $81,88 \%$ & Vencedora \\
\hline Marcopolo S.A. & $3.347,93$ & $6.030,34$ & $80,12 \%$ & Vencedora \\
\hline Bematech S.A. & 148,74 & 265,94 & $78,80 \%$ & Vencedora \\
\hline Jhsf Participações S.A. & $2.779,20$ & $4.787,76$ & $72,27 \%$ & Vencedora \\
\hline Suzano Papel eCelulose S.A. & $8.151,96$ & $14.033,53$ & $72,15 \%$ & Vencedora \\
\hline Iochpe Maxion S.A. & $2.908,28$ & $5.004,76$ & $72,09 \%$ & Vencedora \\
\hline Lojas Renner S.A. & $6.205,66$ & $10.565,28$ & $70,25 \%$ & Vencedora \\
\hline Direcional Engenharia S.A. & $1.637,79$ & $2.690,53$ & $64,28 \%$ & Vencedora \\
\hline $\begin{array}{l}\text { Ez Tec Empreend. e } \\
\text { Participações S.A. }\end{array}$ & $2.168,39$ & $3.500,68$ & $61,44 \%$ & Vencedora \\
\hline Natura Cosméticos S.A. & $16.198,24$ & $25.855,49$ & $59,62 \%$ & Vencedora \\
\hline Klabin S.A. & $8.904,41$ & $14.186,51$ & $59,32 \%$ & Vencedora \\
\hline $\begin{array}{l}\text { Lps Brasil - Consultoria de } \\
\text { Imóveis S.A. }\end{array}$ & $1.335,44$ & $2.094,37$ & $56,83 \%$ & Vencedora \\
\hline Duratex S.A. & $6.082,39$ & $9.529,33$ & $56,67 \%$ & Vencedora \\
\hline Hypermarcas S.A. & $8.058,15$ & $12.624,74$ & $56,67 \%$ & Vencedora \\
\hline Minerva S.A. & $1.920,55$ & $2.987,76$ & $55,57 \%$ & Vencedora \\
\hline $\begin{array}{l}\text { M.Dias Branco S.A. Ind. } \\
\text { Com.de Alimentos }\end{array}$ & $5.879,98$ & $9.132,46$ & $55,31 \%$ & Vencedora \\
\hline B2w - Companhia Digital & $2.610,83$ & $4.049,81$ & $55,12 \%$ & Vencedora \\
\hline Arteris S.A. & $5.999,04$ & $8.947,55$ & $49,15 \%$ & Vencedora \\
\hline $\begin{array}{l}\text { Even Construtora } \\
\text { eIncorporadora S.A. }\end{array}$ & $2.419,30$ & $3.607,77$ & $49,12 \%$ & Vencedora \\
\hline Cer S.A. & $27.768,23$ & $41.065,61$ & $47,89 \%$ & Vencedora \\
\hline $\begin{array}{l}\text { Cia Saneamento Básico } \\
\text { Est.São Paulo }\end{array}$ & $18.300,61$ & $26.940,31$ & $47,21 \%$ & Vencedora \\
\hline $\begin{array}{l}\text { Tpi - Triunfo Particip. } \\
\text { eInvest. S.A. }\end{array}$ & $2.251,35$ & $3.246,46$ & $44,20 \%$ & Vencedora \\
\hline
\end{tabular}


(Conclui)

\begin{tabular}{|c|c|c|c|c|}
\hline \multirow{2}{*}{ Nome das empresas } & \multicolumn{3}{|c|}{ Valor de Mercado } & \multirow{2}{*}{$\begin{array}{l}\text { Classificação } \\
\text { real }\end{array}$} \\
\hline & 2011 & 2012 & \% Variação & \\
\hline $\begin{array}{l}\text { Mrv Engenharia } \\
\text { eParticipações S.A. }\end{array}$ & $7.125,61$ & $7.778,92$ & $9,17 \%$ & Perdedora \\
\hline Tractebel Energia S.A. & $22.425,83$ & $24.126,18$ & $7,58 \%$ & Perdedora \\
\hline Positivo Informática S.A. & 745,65 & 800,97 & $7,42 \%$ & Perdedora \\
\hline $\begin{array}{l}\text { Cosan S.A. Indústria E } \\
\text { Comércio }\end{array}$ & $16.582,22$ & $17.592,75$ & $6,09 \%$ & Perdedora \\
\hline Tecnisa S.A. & $3.023,02$ & $3.201,53$ & $5,91 \%$ & Perdedora \\
\hline Edp - Energias do Brasil S.A. & $11.239,13$ & $11.535,23$ & $2,63 \%$ & Perdedora \\
\hline São Martinho S.A. & $3.368,77$ & $3.441,76$ & $2,17 \%$ & Perdedora \\
\hline Jbs S.A. & $32.543,33$ & $33.005,36$ & $1,42 \%$ & Perdedora \\
\hline Tempo Participações S.A. & 432,37 & 436,25 & $0,90 \%$ & Perdedora \\
\hline Braskem S.A. & $21.599,21$ & $21.747,86$ & $0,69 \%$ & Perdedora \\
\hline $\begin{array}{l}\text { Centrais Elet.deSanta Catarina } \\
\text { S.A. }\end{array}$ & $1.177,96$ & $1.135,25$ & $-3,63 \%$ & Perdedora \\
\hline Rossi Residencial S.A. & $4.579,52$ & $4.329,68$ & $-5,46 \%$ & Perdedora \\
\hline Cpfl Energia S.A. & $37.274,19$ & $35.134,97$ & $-5,74 \%$ & Perdedora \\
\hline Light S.A. & $9.254,76$ & $8.543,67$ & $-7,68 \%$ & Perdedora \\
\hline Gafisa S.A. & $4.648,55$ & $4.260,75$ & $-8,34 \%$ & Perdedora \\
\hline Eternit S.A. & 775,83 & 709,09 & $-8,60 \%$ & Perdedora \\
\hline Csu Cardsystem S.A. & 249,99 & 228,23 & $-8,70 \%$ & Perdedora \\
\hline Diagnósticosda América S.A. & $5.544,17$ & $4.886,05$ & $-11,87 \%$ & Perdedora \\
\hline Trisul S.A. & $1.116,30$ & 980,41 & $-12,17 \%$ & Perdedora \\
\hline Metalfrio Solutions S.A. & 386,15 & 338,84 & $-12,25 \%$ & Perdedora \\
\hline $\begin{array}{l}\text { Pdg Realty S.A. Empreend.e } \\
\text { Participações }\end{array}$ & $11.671,54$ & $10.116,29$ & $-13,33 \%$ & Perdedora \\
\hline $\begin{array}{l}\text { All America Latina Logística } \\
\text { S.A. }\end{array}$ & $11.197,95$ & $9.672,96$ & $-13,62 \%$ & Perdedora \\
\hline $\begin{array}{l}\text { Rodobens } \\
\text { NegóciosImobiliários S.A. }\end{array}$ & $1.112,17$ & 957,65 & $-13,89 \%$ & Perdedora \\
\hline $\begin{array}{l}\text { Cia Energéticade Minas } \\
\text { Gerais - Cemig }\end{array}$ & $31.179,58$ & $26.405,60$ & $-15,31 \%$ & Perdedora \\
\hline $\begin{array}{l}\text { Usinas Sid.de Minas Gerais } \\
\text { S.A.-Usiminas }\end{array}$ & $22.232,82$ & $18.736,53$ & $-15,73 \%$ & Perdedora \\
\hline $\begin{array}{l}\text { Cia Paranaense de Energia - } \\
\text { Copel }\end{array}$ & $9.719,45$ & $8.118,89$ & $-16,47 \%$ & Perdedora \\
\hline $\begin{array}{l}\text { Cr2 Empreendimentos } \\
\text { Imobiliários S.A. }\end{array}$ & 519,19 & 422,93 & $-18,54 \%$ & Perdedora \\
\hline Indústrias Romi S.A. & $1.329,59$ & $1.059,43$ & $-20,32 \%$ & Perdedora \\
\hline Ideiasnet S.A. & 466,37 & 353,39 & $-24,23 \%$ & Perdedora \\
\hline $\begin{array}{l}\text { Eletropaulo Metrop. Elet. São } \\
\text { Paulo S.A. }\end{array}$ & $7.213,57$ & $4.799,56$ & $-33,46 \%$ & Perdedora \\
\hline $\begin{array}{l}\text { Eletropaulo Metrop. Elet. São } \\
\text { Paulo S.A. }\end{array}$ & $11.154,99$ & $7.354,79$ & $-34,07 \%$ & Perdedora \\
\hline $\begin{array}{l}\text { Cteep - Cia Transmissão } \\
\text { Energia Elétrica Paulista }\end{array}$ & $11.416,91$ & $7.247,68$ & $-36,52 \%$ & Perdedora \\
\hline $\begin{array}{l}\text { Centrais Elet. Bras. S.A. - } \\
\text { Eletrobras }\end{array}$ & $53.230,02$ & $24.717,33$ & $-53,57 \%$ & Perdedora \\
\hline
\end{tabular}

Fonte: Elaborada pela autora. 
Tabela A4 - Empresas da amostra no exercício de 2013

\begin{tabular}{|c|c|c|c|c|}
\hline \multirow{2}{*}{ Nome das empresas } & \multicolumn{3}{|c|}{ Valor de Mercado } & \multirow{2}{*}{$\begin{array}{l}\text { Classificação } \\
\text { real }\end{array}$} \\
\hline & 2012 & 2013 & \% Variação & \\
\hline $\begin{array}{l}\text { Profarma Distrib. } \\
\text { Prod.Farmacêuticos S.A. }\end{array}$ & 654,69 & $1.085,86$ & $65,86 \%$ & Vencedora \\
\hline Bematech S.A. & 265,94 & 412,87 & $55,25 \%$ & Vencedora \\
\hline Cosan S.A. Indústria e Comércio & $17.592,75$ & $27.156,86$ & $54,36 \%$ & Vencedora \\
\hline EstácioParticipações S.A. & $3.565,30$ & $5.487,65$ & $53,92 \%$ & Vencedora \\
\hline Jbs S.A & $33.005,36$ & $50.086,00$ & $51,75 \%$ & Vencedora \\
\hline Suzano Papel eCelulose S.A. & $14.033,53$ & $19.210,88$ & $36,89 \%$ & Vencedora \\
\hline Paranapanema S.A. & $1.753,40$ & $2.326,20$ & $32,67 \%$ & Vencedora \\
\hline Embraer S.A. & $9.947,82$ & $12.927,92$ & $29,96 \%$ & Vencedora \\
\hline Equatorial Energia S.A. & $5.171,63$ & $6.700,15$ & $29,56 \%$ & Vencedora \\
\hline $\begin{array}{l}\text { Eletropaulo Metrop. Elet. São Paulo } \\
\text { S.A. }\end{array}$ & $24.717,33$ & $31.458,08$ & $27,27 \%$ & Vencedora \\
\hline $\begin{array}{l}\text { M.Dias Branco S.A. Ind. Com.de } \\
\text { Alimentos }\end{array}$ & $9.132,46$ & $11.606,82$ & $27,09 \%$ & Vencedora \\
\hline Braskem S.A. & $21.747,86$ & $27.432,07$ & $26,14 \%$ & Vencedora \\
\hline Portobello S.A. & 818,42 & $1.024,74$ & $25,21 \%$ & Vencedora \\
\hline São Martinho S.A. & $3.441,76$ & $4.078,33$ & $18,50 \%$ & Vencedora \\
\hline Minerva S.A. & $2.987,76$ & $3.534,29$ & $18,29 \%$ & Vencedora \\
\hline Tecnisa S.A. & $3.201,53$ & $3.721,84$ & $16,25 \%$ & Vencedora \\
\hline Metalfrio Solutions S.A. & 338,84 & 390,20 & $15,16 \%$ & Vencedora \\
\hline Eternit S.A. & 709,09 & 815,72 & $15,04 \%$ & Vencedora \\
\hline Grendene S.A. & $4.224,16$ & $4.821,13$ & $14,13 \%$ & Vencedora \\
\hline $\begin{array}{l}\text { Ez Tec Empreend. e Participações } \\
\text { S.A. }\end{array}$ & $3.500,68$ & $3.991,68$ & $14,03 \%$ & Vencedora \\
\hline Fibria Celulose S.A. & $20.003,89$ & $22.728,67$ & $13,62 \%$ & Vencedora \\
\hline Weg S.A & $16.953,02$ & $19.250,12$ & $13,55 \%$ & Vencedora \\
\hline Brf S.A. & $43.637,19$ & $49.460,36$ & $13,34 \%$ & Vencedora \\
\hline Saraiva S.A. Livreiros Editores & $1.022,00$ & $1.157,16$ & $13,23 \%$ & Vencedora \\
\hline Vanguarda Agro S.A. & $1.717,07$ & $1.924,12$ & $12,06 \%$ & Vencedora \\
\hline Fras-Le S.A. & 686,76 & 768,18 & $11,86 \%$ & Vencedora \\
\hline Hypermarcas S.A. & $12.624,74$ & $13.899,38$ & $10,10 \%$ & Vencedora \\
\hline Log-In Logística Intermodal S.A. & $1.738,17$ & $1.912,98$ & $10,06 \%$ & Vencedora \\
\hline Slc Agrícola S.A. & $2.651,76$ & $2.914,69$ & $9,92 \%$ & Vencedora \\
\hline Diagnósticosda América S.A. & $4.886,05$ & $5.352,09$ & $9,54 \%$ & Vencedora \\
\hline Alpargatas S.A. & $5.473,48$ & $5.980,92$ & $9,27 \%$ & Vencedora \\
\hline Arteris S.A. & $8.947,55$ & $9.645,49$ & $7,80 \%$ & Vencedora \\
\hline Cia Brasileira de Distribuição & $29.775,66$ & $32.052,32$ & $7,65 \%$ & Vencedora \\
\hline
\end{tabular}


(Conclui)

\begin{tabular}{|c|c|c|c|c|}
\hline \multirow{2}{*}{ Nome das empresas } & \multicolumn{3}{|c|}{ Valor de Mercado } & \multirow{2}{*}{$\begin{array}{c}\text { Classificação } \\
\text { real }\end{array}$} \\
\hline & 2012 & 2013 & \% Variação & \\
\hline Marcopolo S.A. & $6.030,34$ & $5.433,44$ & $-9,90 \%$ & Perdedora \\
\hline Csu Cardsystem S.A. & 228,23 & 205,55 & $-9,94 \%$ & Perdedora \\
\hline Ideiasnet S.A. & 353,39 & 308,44 & $-12,72 \%$ & Perdedora \\
\hline $\begin{array}{l}\text { Cyrela Brazil Realty } \\
\text { S.A.Empreend.ePart. }\end{array}$ & $10.829,57$ & $9.313,32$ & $-14,00 \%$ & Perdedora \\
\hline Direcional Engenharia S.A. & $2.690,53$ & $2.310,24$ & $-14,13 \%$ & Perdedora \\
\hline Indústrias Romi S.A. & $1.059,43$ & 906,99 & $-14,39 \%$ & Perdedora \\
\hline Brasil Brokers Participações S.A. & $1.079,55$ & 909,84 & $-15,72 \%$ & Perdedora \\
\hline Fleury S.A. & $3.982,40$ & $3.320,38$ & $-16,62 \%$ & Perdedora \\
\hline Lojas Renner S.A. & $10.565,28$ & $8.660,45$ & $-18,03 \%$ & Perdedora \\
\hline Edp - Energias do Brasil S.A. & $11.535,23$ & $9.413,02$ & $-18,40 \%$ & Perdedora \\
\hline Positivo Informática S.A. & 800,97 & 636,38 & $-20,55 \%$ & Perdedora \\
\hline Bhg Sa - Brazil Hospitality Group & $1.081,48$ & 855,33 & $-20,91 \%$ & Perdedora \\
\hline Lps Brasil - Consultoria de Imóveis S.A. & $2.094,37$ & $1.593,81$ & $-23,90 \%$ & Perdedora \\
\hline Mrv Engenharia e Participações S.A. & $7.778,92$ & $5.853,18$ & $-24,76 \%$ & Perdedora \\
\hline Rossi Residencial S.A. & $4.329,68$ & $3.256,31$ & $-24,79 \%$ & Perdedora \\
\hline Natura Cosméticos S.A. & $25.855,49$ & $19.356,26$ & $-25,14 \%$ & Perdedora \\
\hline Trisul S.A. & 980,41 & 733,85 & $-25,15 \%$ & Perdedora \\
\hline $\begin{array}{l}\text { Pdg Realty S.A. Empreend.e } \\
\text { Participações }\end{array}$ & $10.116,29$ & $7.478,93$ & $-26,07 \%$ & Perdedora \\
\hline $\begin{array}{l}\text { Valid Soluções eServ. Seg. Meios Pag. } \\
\text { Ident. S.A. }\end{array}$ & $2.813,37$ & $2.050,08$ & $-27,13 \%$ & Perdedora \\
\hline Fertilizantes Heringer S.A. & $1.265,93$ & 910,71 & $-28,06 \%$ & Perdedora \\
\hline Cia Hering & $6.725,99$ & $4.804,52$ & $-28,57 \%$ & Perdedora \\
\hline Jhsf Participações S.A. & $4.787,76$ & $3.404,33$ & $-28,90 \%$ & Perdedora \\
\hline Marfrig Global Foods S.A. & $13.537,10$ & $9.450,80$ & $-30,19 \%$ & Perdedora \\
\hline $\begin{array}{l}\text { Eletropaulo Metrop. Elet. São Paulo } \\
\text { S.A. }\end{array}$ & $4.799,56$ & $3.339,99$ & $-30,41 \%$ & Perdedora \\
\hline Cr2 Empreendimentos Imobiliários S.A. & 422,93 & 288,14 & $-31,87 \%$ & Perdedora \\
\hline Kroton Educacional S.A. & $15.843,41$ & $10.662,77$ & $-32,70 \%$ & Perdedora \\
\hline $\begin{array}{l}\text { Cteep - Cia Transmissão Energia } \\
\text { Elétrica Paulista }\end{array}$ & $7.247,68$ & $4.749,09$ & $-34,47 \%$ & Perdedora \\
\hline Santos Brasil Participações S.A. & $4.175,40$ & $2.719,41$ & $-34,87 \%$ & Perdedora \\
\hline Raia Drogasil S.A. & $7.647,21$ & $4.886,05$ & $-36,11 \%$ & Perdedora \\
\hline Marisa Lojas S.A. & $6.516,03$ & $3.977,24$ & $-38,96 \%$ & Perdedora \\
\hline Gafisa S.A & $4.260,75$ & $2.529,23$ & $-40,64 \%$ & Perdedora \\
\hline Tegma GestãoLogística S.A. & $2.592,39$ & $1.510,53$ & $-41,73 \%$ & Perdedora \\
\hline Centrais Elet.deSanta Catarina S.A. & $1.135,25$ & 605,43 & $-46,67 \%$ & Perdedora \\
\hline
\end{tabular}

Fonte: Elaborada pela autora. 
Tabela A5 - Empresas da amostra no exercício de 2014

\begin{tabular}{|c|c|c|c|c|}
\hline \multirow{2}{*}{ Nome das empresas } & \multicolumn{3}{|c|}{ Valor de Mercado } & \multirow{2}{*}{$\begin{array}{c}\text { Classificação } \\
\text { real }\end{array}$} \\
\hline & 2013 & 2014 & \% Variação & \\
\hline Kroton Educacional S.A. & $10.662,77$ & $25.618,10$ & $140,26 \%$ & Vencedora \\
\hline Raia Drogasil S.A. & $4.886,05$ & $8.347,45$ & $70,84 \%$ & Vencedora \\
\hline $\begin{array}{l}\text { Cteep - Cia Transmissão Energia } \\
\text { Elétrica Paulista }\end{array}$ & $4.749,09$ & $7.463,41$ & $57,15 \%$ & Vencedora \\
\hline B2w - Companhia Digital & $4.129,73$ & $6.131,44$ & $48,47 \%$ & Vencedora \\
\hline Klabin S.A. & $13.741,98$ & $20.262,20$ & $47,45 \%$ & Vencedora \\
\hline Embraer S.A. & $12.927,92$ & $18.330,76$ & $41,79 \%$ & Vencedora \\
\hline Bhg Sa - Brazil Hospitality Group & 855,33 & $1.199,53$ & $40,24 \%$ & Vencedora \\
\hline Centrais Elet.deSanta Catarina S.A. & 605,43 & 846,79 & $39,87 \%$ & Vencedora \\
\hline Fertilizantes Heringer S.A. & 910,71 & $1.273,04$ & $39,78 \%$ & Vencedora \\
\hline Cia Paranaense de Energia - Copel & $8.612,92$ & $11.832,10$ & $37,38 \%$ & Vencedora \\
\hline Centrais Elet. Bras. S.A. - Eletrobras & $31.458,08$ & $42.674,25$ & $35,65 \%$ & Vencedora \\
\hline EstácioParticipações S.A. & $5.487,65$ & $7.275,56$ & $32,58 \%$ & Vencedora \\
\hline Minerva S.A. & $3.534,29$ & $4.614,61$ & $30,57 \%$ & Vencedora \\
\hline $\begin{array}{l}\text { Valid Soluções eServ. Seg. Meios Pag. } \\
\text { Ident. S.A. }\end{array}$ & $2.050,08$ & $2.656,07$ & $29,56 \%$ & Vencedora \\
\hline Weg S.A. & $19.250,12$ & $24.663,75$ & $28,12 \%$ & Vencedora \\
\hline Equatorial Energia S.A. & $6.700,15$ & $8.517,38$ & $27,12 \%$ & Vencedora \\
\hline Lojas Renner S.A. & $8.660,45$ & $10.862,56$ & $25,43 \%$ & Vencedora \\
\hline Marfrig Global Foods S.A. & $9.450,80$ & $11.833,57$ & $25,21 \%$ & Vencedora \\
\hline Ideiasnet S.A. & 308,44 & 374,74 & $21,49 \%$ & Vencedora \\
\hline Brf S.A. & $49.460,36$ & $60.052,79$ & $21,42 \%$ & Vencedora \\
\hline Tpi - Triunfo Particip. eInvest. S.A. & $3.111,70$ & $3.769,03$ & $21,12 \%$ & Vencedora \\
\hline Cia Energéticade Minas Gerais - Cemig & $24.100,17$ & $28.978,64$ & $20,24 \%$ & Vencedora \\
\hline Jbs S.A & $50.086,00$ & $59.292,14$ & $18,38 \%$ & Vencedora \\
\hline Tempo Participações S.A. & 435,75 & 508,92 & $16,79 \%$ & Vencedora \\
\hline Suzano Papel eCelulose S.A. & $19.210,88$ & $22.298,70$ & $16,07 \%$ & Vencedora \\
\hline Prumo Logística S.A. & $3.244,92$ & $3.708,91$ & $14,30 \%$ & Vencedora \\
\hline Light S.A. & $8.535,90$ & $9.547,42$ & $11,85 \%$ & Vencedora \\
\hline São Martinho S.A. & $4.078,33$ & $4.522,08$ & $10,88 \%$ & Vencedora \\
\hline Fibria Celulose S.A. & $22.728,67$ & $25.169,08$ & $10,74 \%$ & Vencedora \\
\hline Portobello S.A. & $1.024,74$ & $1.115,74$ & $8,88 \%$ & Vencedora \\
\hline Bematech S.A. & 412,87 & 447,33 & $8,35 \%$ & Vencedora \\
\hline $\begin{array}{l}\text { Eletropaulo Metrop. Elet. São Paulo } \\
\text { S.A. }\end{array}$ & $3.339,99$ & $3.611,94$ & $8,14 \%$ & Vencedora \\
\hline Cpfl Energia S.A. & $32.934,80$ & $35.020,61$ & $6,33 \%$ & Vencedora \\
\hline
\end{tabular}


(Conclui)

\begin{tabular}{|c|c|c|c|c|}
\hline \multirow{2}{*}{ Nome das empresas } & \multicolumn{3}{|c|}{ Valor de Mercado } & \multirow{2}{*}{$\begin{array}{c}\text { Classificação } \\
\text { real }\end{array}$} \\
\hline & 2013 & 2014 & \% Variação & \\
\hline Cia Saneamento Básico Est. São Paulo & $25.753,74$ & $20.689,28$ & $-19,66 \%$ & Perdedora \\
\hline $\begin{array}{l}\text { Ez Tec Empreend. e Participações } \\
\text { S.A. }\end{array}$ & $3.991,68$ & $3.202,91$ & $-19,76 \%$ & Perdedora \\
\hline $\begin{array}{l}\text { Cyrela Brazil Realty } \\
\text { S.A.Empreend.ePart. }\end{array}$ & $9.313,32$ & $7.418,26$ & $-20,35 \%$ & Perdedora \\
\hline Diagnósticosda América S.A. & $5.352,09$ & $4.225,13$ & $-21,06 \%$ & Perdedora \\
\hline Rodobens NegóciosImobiliários S.A. & 909,51 & 717,80 & $-21,08 \%$ & Perdedora \\
\hline Even Construtora eIncorporadora S.A. & $3.347,07$ & $2.626,41$ & $-21,53 \%$ & Perdedora \\
\hline Grendene S.A. & $4.821,13$ & $3.778,86$ & $-21,62 \%$ & Perdedora \\
\hline Cosan S.A. Indústria e Comércio & $27.156,86$ & $21.197,38$ & $-21,94 \%$ & Perdedora \\
\hline Marcopolo S.A. & $5.433,44$ & $4.237,09$ & $-22,02 \%$ & Perdedora \\
\hline Duratex S.A. & $9.392,05$ & $7.117,08$ & $-24,22 \%$ & Perdedora \\
\hline Positivo Informática S.A. & 636,38 & 477,18 & $-25,02 \%$ & Perdedora \\
\hline Vale S.A. & $244.315,08$ & $182.059,36$ & $-25,48 \%$ & Perdedora \\
\hline Iochpe Maxion S.A. & $4.809,33$ & $3.550,52$ & $-26,17 \%$ & Perdedora \\
\hline Santos Brasil Participações S.A. & $2.719,41$ & $1.987,39$ & $-26,92 \%$ & Perdedora \\
\hline Trisul S.A. & 733,85 & 528,73 & $-27,95 \%$ & Perdedora \\
\hline Rossi Residencial S.A. & $3.256,31$ & $2.299,79$ & $-29,37 \%$ & Perdedora \\
\hline Direcional Engenharia S.A. & $2.310,24$ & $1.629,18$ & $-29,48 \%$ & Perdedora \\
\hline Magnesita Refratários S.A. & $3.177,06$ & $2.198,56$ & $-30,80 \%$ & Perdedora \\
\hline Gerdau S.A. & $45.421,37$ & $31.055,92$ & $-31,63 \%$ & Perdedora \\
\hline Vanguarda Agro S.A. & $1.924,12$ & $1.313,57$ & $-31,73 \%$ & Perdedora \\
\hline Fras-Le S.A. & 768,18 & 512,38 & $-33,30 \%$ & Perdedora \\
\hline Cia Hering & $4.804,52$ & $3.160,88$ & $-34,21 \%$ & Perdedora \\
\hline Eucatex S.A. Indústria e Comércio & 835,03 & 530,07 & $-36,52 \%$ & Perdedora \\
\hline $\begin{array}{l}\text { Randon S.A. Implementos e } \\
\text { Participações }\end{array}$ & $3.881,52$ & $2.430,92$ & $-37,37 \%$ & Perdedora \\
\hline Indústrias Romi S.A. & 906,99 & 551,78 & $-39,16 \%$ & Perdedora \\
\hline Cia Providencia Indústria e Comércio & $1.158,06$ & 701,25 & $-39,45 \%$ & Perdedora \\
\hline Saraiva S.A. Livreiros Editores & $1.157,16$ & 698,40 & $-39,65 \%$ & Perdedora \\
\hline Alpargatas S.A. & $5.980,92$ & $3.472,00$ & $-41,95 \%$ & Perdedora \\
\hline $\begin{array}{l}\text { Profarma Distrib. Prod.Farmacêuticos } \\
\text { S.A. }\end{array}$ & $1.085,86$ & 604,05 & $-44,37 \%$ & Perdedora \\
\hline $\begin{array}{l}\text { Cr2 Empreendimentos Imobiliários } \\
\text { S.A. }\end{array}$ & 288,14 & 155,50 & $-46,04 \%$ & Perdedora \\
\hline Paranapanema S.A. & $2.326,20$ & $1.073,51$ & $-53,85 \%$ & Perdedora \\
\hline $\begin{array}{l}\text { Lps Brasil - Consultoria de Imóveis } \\
\text { S.A. }\end{array}$ & $1.593,81$ & 680,07 & $-57,33 \%$ & Perdedora \\
\hline Brasil Brokers Participações S.A. & 909,84 & 380,05 & $-58,23 \%$ & Perdedora \\
\hline
\end{tabular}

Fonte: Elaborada pela autora. 


\section{APÊNDICE C - CLASSIFICAÇÃO DAS EMPRESAS PELO MÉTODO DE ANÁLISE DISCRIMINANTE}

Tabela A6 - Detalhamento da Classificação de empresas - Exercício 2010

\begin{tabular}{|c|c|c|c|c|c|}
\hline Empresa & $\begin{array}{l}\text { Grupo } \\
\text { Atual }\end{array}$ & $\begin{array}{c}\mathrm{Z} \\
\text { Discriminante } \\
\end{array}$ & $\begin{array}{c}\text { Ponto de Corte } \\
(\mathrm{Z} \text { ec })\end{array}$ & $\begin{array}{c}\text { Grupo } \\
\text { Previsto }\end{array}$ & Análise \\
\hline $\begin{array}{l}\text { All America Latina } \\
\text { Logistica S.A. }\end{array}$ & Perdedoras & $-1,149$ & 0,021 & Perdedoras & Ok \\
\hline Prumo Logística S.A. & Perdedoras & $-0,921$ & 0,021 & Perdedoras & Ok \\
\hline Positivo Informatica S.A. & Perdedoras & $-1,101$ & 0,021 & Perdedoras & Ok \\
\hline Rossi Residencial S.A. & Perdedoras & 0,238 & 0,021 & Vencedoras & Erro \\
\hline Hypermarcas S.A. & Perdedoras & 0,420 & 0,021 & Vencedoras & Erro \\
\hline $\begin{array}{l}\text { Saraiva S.A. Livreiros } \\
\text { Editores }\end{array}$ & Perdedoras & $-0,694$ & 0,021 & Perdedoras & Ok \\
\hline Csu Cardsystem S.A. & Perdedoras & $-1,213$ & 0,021 & Perdedoras & Ok \\
\hline Magnesita Refratarios S.A. & Perdedoras & $-0,771$ & 0,021 & Perdedoras & Ok \\
\hline B2w - Companhia Digital & Perdedoras & $-1,461$ & 0,021 & Perdedoras & Ok \\
\hline $\begin{array}{l}\text { Centrais Elet Bras S.A. - } \\
\text { Eletrobras }\end{array}$ & Perdedoras & $-0,640$ & 0,021 & Perdedoras & Ok \\
\hline Fibria Celulose S.A. & Perdedoras & $-0,779$ & 0,021 & Perdedoras & Ok \\
\hline Ideiasnet S.A. & Perdedoras & $-0,794$ & 0,021 & Perdedoras & Ok \\
\hline Grendene S.A. & Perdedoras & 1,558 & 0,021 & Vencedoras & Erro \\
\hline Gerdau S.A. & Perdedoras & $-0,721$ & 0,021 & Perdedoras & Ok \\
\hline $\begin{array}{l}\text { Suzano Papel E Celulose } \\
\text { S.A. }\end{array}$ & Perdedoras & $-0,849$ & 0,021 & Perdedoras & Ok \\
\hline Jhsf Participacoes S.A. & Perdedoras & 0,236 & 0,021 & Vencedoras & Erro \\
\hline Paranapanema S.A. & Perdedoras & $-0,490$ & 0,021 & Perdedoras & Ok \\
\hline Metalurgica Gerdau S.A. & Perdedoras & $-0,807$ & 0,021 & Perdedoras & Ok \\
\hline $\begin{array}{l}\text { Eletropaulo Metrop. Elet. } \\
\text { Sao Paulo S.A. }\end{array}$ & Perdedoras & $-1,149$ & 0,021 & Perdedoras & Ok \\
\hline $\begin{array}{l}\text { Profarma Distrib Prod } \\
\text { Farmaceuticos S.A. }\end{array}$ & Perdedoras & $-1,100$ & 0,021 & Perdedoras & Ok \\
\hline $\begin{array}{l}\text { M.Dias Branco S.A. Ind } \\
\text { Com De Alimentos }\end{array}$ & Perdedoras & 0,105 & 0,021 & Vencedoras & Erro \\
\hline $\begin{array}{l}\text { Usinas Sid De Minas } \\
\text { Gerais S.A.-Usiminas }\end{array}$ & Perdedoras & $-0,361$ & 0,021 & Perdedoras & Ok \\
\hline Jbs S.A. & Perdedoras & 0,171 & 0,021 & Vencedoras & Erro \\
\hline $\begin{array}{l}\text { Cyrela Brazil Realty } \\
\text { S.A.Empreend E Part }\end{array}$ & Perdedoras & $-0,893$ & 0,021 & Perdedoras & Ok \\
\hline Equatorial Energia S.A. & Perdedoras & $-1,119$ & 0,021 & Perdedoras & Ok \\
\hline $\begin{array}{l}\text { Cia Saneamento De Minas } \\
\text { Gerais-Copasa Mg }\end{array}$ & Perdedoras & $-0,917$ & 0,021 & Perdedoras & Ok \\
\hline Bematech S.A. & Perdedoras & 0,220 & 0,021 & Vencedoras & Erro \\
\hline $\begin{array}{l}\text { Cia Paranaense De Energia } \\
\text { - Copel }\end{array}$ & Perdedoras & $-0,435$ & 0,021 & Perdedoras & Ok \\
\hline Klabin S.A. & Perdedoras & $-0,677$ & 0,021 & Perdedoras & Ok \\
\hline Light S.A. & Perdedoras & $-1,261$ & 0,021 & Perdedoras & Ok \\
\hline $\begin{array}{l}\text { Randon S.A. Implementos } \\
\text { E Participacoes }\end{array}$ & Perdedoras & 0,021 & 0,021 & Vencedoras & Erro \\
\hline
\end{tabular}


(Conclui)

\begin{tabular}{|c|c|c|c|c|c|}
\hline Empresa & $\begin{array}{l}\text { Grupo } \\
\text { Atual } \\
\end{array}$ & $\begin{array}{c}\mathrm{Z} \\
\text { Discriminante } \\
\end{array}$ & $\begin{array}{c}\text { Ponto de Corte } \\
(\mathrm{Z} \text { ec })\end{array}$ & $\begin{array}{l}\text { Grupo } \\
\text { Previsto }\end{array}$ & Análise \\
\hline $\begin{array}{l}\text { Cia Providencia Industria E } \\
\text { Comercio }\end{array}$ & Perdedoras & $-0,814$ & 0,021 & Perdedoras & Ok \\
\hline Lojas Renner S.A. & Vencedoras & $-0,868$ & 0,021 & Perdedoras & Erro \\
\hline $\begin{array}{l}\text { Eucatex S.A. Industria E } \\
\text { Comercio }\end{array}$ & Vencedoras & $-0,410$ & 0,021 & Perdedoras & Erro \\
\hline Totvs S.A. & Vencedoras & $-0,868$ & 0,021 & Perdedoras & Erro \\
\hline Direcional Engenharia S.A. & Vencedoras & 1,548 & 0,021 & Vencedoras & $\mathrm{Ok}$ \\
\hline Tempo Participacoes S.A. & Vencedoras & $-0,379$ & 0,021 & Perdedoras & Erro \\
\hline $\begin{array}{l}\text { Brasil Brokers Participacoes } \\
\text { S.A. }\end{array}$ & Vencedoras & 1,876 & 0,021 & Vencedoras & Ok \\
\hline $\begin{array}{l}\text { Log-In Logistica Intermodal } \\
\text { S.A. }\end{array}$ & Vencedoras & 0,112 & 0,021 & Vencedoras & Ok \\
\hline $\begin{array}{l}\text { Diagnosticos Da America } \\
\text { S.A. }\end{array}$ & Vencedoras & $-1,218$ & 0,021 & Perdedoras & Erro \\
\hline Raia Drogasil S.A. & Vencedoras & $-0,207$ & 0,021 & Perdedoras & Erro \\
\hline Arteris S.A. & Vencedoras & $-1,070$ & 0,021 & Perdedoras & Erro \\
\hline $\begin{array}{l}\text { Tpi - Triunfo Particip. E } \\
\text { Invest. S.A. }\end{array}$ & Vencedoras & $-0,659$ & 0,021 & Perdedoras & Erro \\
\hline Fleury S.A. & Vencedoras & 0,488 & 0,021 & Vencedoras & Ok \\
\hline Iochpe Maxion S.A. & Vencedoras & 0,381 & 0,021 & Vencedoras & $\mathrm{Ok}$ \\
\hline Tegma Gestao Logistica S.A. & Vencedoras & $-0,121$ & 0,021 & Perdedoras & Erro \\
\hline Marcopolo S.A. & Vencedoras & $-0,258$ & 0,021 & Perdedoras & Erro \\
\hline $\begin{array}{l}\text { Ez Tec Empreend. E } \\
\text { Participacoes S.A. }\end{array}$ & Vencedoras & 1,382 & 0,021 & Vencedoras & $\mathrm{Ok}$ \\
\hline Vanguarda Agro S.A. & Vencedoras & $-0,740$ & 0,021 & Perdedoras & Erro \\
\hline $\begin{array}{l}\text { Helbor Empreendimentos } \\
\text { S.A. }\end{array}$ & Vencedoras & $-0,117$ & 0,021 & Perdedoras & Erro \\
\hline Alpargatas S.A. & Vencedoras & $-0,418$ & 0,021 & Perdedoras & Erro \\
\hline Braskem S.A. & Vencedoras & 0,010 & 0,021 & Perdedoras & Erro \\
\hline Trisul S.A. & Vencedoras & $-0,480$ & 0,021 & Perdedoras & Erro \\
\hline $\begin{array}{l}\text { Lps Brasil - Consultoria De } \\
\text { Imoveis S.A. }\end{array}$ & Vencedoras & $-0,124$ & 0,021 & Perdedoras & Erro \\
\hline Odontoprev S.A. & Vencedoras & 2,540 & 0,021 & Vencedoras & Ok \\
\hline $\begin{array}{l}\text { Pdg Realty S.A. Empreend E } \\
\text { Participacoes }\end{array}$ & Vencedoras & 2,731 & 0,021 & Vencedoras & Ok \\
\hline $\begin{array}{l}\text { Cosan S.A. Industria E } \\
\text { Comercio }\end{array}$ & Vencedoras & 2,782 & 0,021 & Vencedoras & Ok \\
\hline Eternit S.A. & Vencedoras & 0,021 & 0,021 & Vencedoras & Ok \\
\hline Kroton Educacional S.A. & Vencedoras & 1,897 & 0,021 & Vencedoras & Ok \\
\hline $\begin{array}{l}\text { Bhg Sa - Brazil Hospitality } \\
\text { Group }\end{array}$ & Vencedoras & 2,119 & 0,021 & Vencedoras & Ok \\
\hline Tereos Internacional S.A. & Vencedoras & $-1,586$ & 0,021 & Perdedoras & Erro \\
\hline Marisa Lojas S.A. & Vencedoras & $-0,850$ & 0,021 & Perdedoras & Erro \\
\hline Cia Hering & Vencedoras & 0,162 & 0,021 & Vencedoras & Ok \\
\hline
\end{tabular}

Fonte: Elaborada pela autora. 
Tabela A7 - Detalhamento da Classificação de empresas - Exercício 2011

\begin{tabular}{|c|c|c|c|c|c|}
\hline Empresa & $\begin{array}{l}\text { Grupo } \\
\text { Atual }\end{array}$ & $\begin{array}{c}\mathrm{Z} \\
\text { Discriminante }\end{array}$ & $\begin{array}{c}\text { Ponto de } \\
\text { Corte }(\mathrm{Z} \text { ec })\end{array}$ & $\begin{array}{l}\text { Grupo } \\
\text { Previsto }\end{array}$ & Análise \\
\hline $\begin{array}{l}\text { Valid Soluções E Serv. Seg. } \\
\text { Meios Pag. Ident. S.A. }\end{array}$ & Vencedoras & 0,033 & 0,050 & Perdedoras & Erro \\
\hline $\begin{array}{l}\text { Tpi - Triunfo Particip. E } \\
\text { Invest. S.A. }\end{array}$ & Vencedoras & 1,130 & 0,050 & Vencedoras & Ok \\
\hline Tegma Gestao Logistica S.A. & Vencedoras & $-0,151$ & 0,050 & Perdedoras & Erro \\
\hline Tecnisa S.A. & Vencedoras & $-0,804$ & 0,050 & Perdedoras & Erro \\
\hline Sao Martinho S.A. & Vencedoras & 1,589 & 0,050 & Vencedoras & $\mathrm{Ok}$ \\
\hline $\begin{array}{l}\text { Santos Brasil Participacoes } \\
\text { S.A. }\end{array}$ & Vencedoras & 1,373 & 0,050 & Vencedoras & Ok \\
\hline $\begin{array}{l}\text { Cia Saneamento Basico Est } \\
\text { Sao Paulo }\end{array}$ & Vencedoras & 1,089 & 0,050 & Vencedoras & Ok \\
\hline Cia Brasileira De Distribuicao & Vencedoras & $-0,009$ & 0,050 & Perdedoras & Erro \\
\hline $\begin{array}{l}\text { M.Dias Branco S.A. Ind Com } \\
\text { De Alimentos }\end{array}$ & Vencedoras & 0,113 & 0,050 & Vencedoras & Ok \\
\hline Light S.A. & Vencedoras & 0,647 & 0,050 & Vencedoras & Ok \\
\hline Kroton Educacional S.A. & Vencedoras & 0,572 & 0,050 & Vencedoras & Ok \\
\hline Jhsf Participacoes S.A. & Vencedoras & $-0,163$ & 0,050 & Perdedoras & Erro \\
\hline Iochpe Maxion S.A. & Vencedoras & 0,854 & 0,050 & Vencedoras & $\mathrm{Ok}$ \\
\hline Helbor Empreendimentos S.A. & Vencedoras & $-0,025$ & 0,050 & Perdedoras & Erro \\
\hline Fleury S.A. & Vencedoras & $-0,309$ & 0,050 & Perdedoras & Erro \\
\hline $\begin{array}{l}\text { Ez Tec Empreend. E } \\
\text { Participacoes S.A. }\end{array}$ & Vencedoras & $-1,726$ & 0,050 & Perdedoras & Erro \\
\hline $\begin{array}{l}\text { Eletropaulo Metrop. Elet. Sao } \\
\text { Paulo S.A. }\end{array}$ & Vencedoras & 1,484 & 0,050 & Vencedoras & Ok \\
\hline Raia Drogasil S.A. & Vencedoras & $-0,699$ & 0,050 & Perdedoras & Erro \\
\hline Cpfl Energia S.A. & Vencedoras & 1,032 & 0,050 & Vencedoras & $\mathrm{Ok}$ \\
\hline $\begin{array}{l}\text { Cosan S.A. Industria E } \\
\text { Comercio }\end{array}$ & Vencedoras & 0,567 & 0,050 & Vencedoras & $\mathrm{Ok}$ \\
\hline $\begin{array}{l}\text { Cesp - Cia Energetica De Sao } \\
\text { Paulo }\end{array}$ & Vencedoras & 1,835 & 0,050 & Vencedoras & Ok \\
\hline $\begin{array}{l}\text { Cia Energetica De Minas } \\
\text { Gerais - Cemig }\end{array}$ & Vencedoras & 1,479 & 0,050 & Vencedoras & $\mathrm{Ok}$ \\
\hline $\begin{array}{l}\text { Cia Saneamento De Minas } \\
\text { Gerais-Copasa Mg }\end{array}$ & Vencedoras & 1,176 & 0,050 & Vencedoras & Ok \\
\hline Cia Hering & Vencedoras & $-0,773$ & 0,050 & Perdedoras & Erro \\
\hline $\begin{array}{l}\text { Cteep - Cia Transmissão } \\
\text { Energia Elétrica Paulista }\end{array}$ & Vencedoras & 1,249 & 0,050 & Vencedoras & Ok \\
\hline $\begin{array}{l}\text { Centrais Elet Bras S.A. - } \\
\text { Eletrobras }\end{array}$ & Vencedoras & $-0,157$ & 0,050 & Perdedoras & Erro \\
\hline Ccr S.A. & Vencedoras & 1,690 & 0,050 & Vencedoras & $\mathrm{Ok}$ \\
\hline $\begin{array}{l}\text { Bhg Sa - Brazil Hospitality } \\
\text { Group }\end{array}$ & Vencedoras & 0,981 & 0,050 & Vencedoras & Ok \\
\hline Arteris S.A. & Vencedoras & 1,009 & 0,050 & Vencedoras & $\mathrm{Ok}$ \\
\hline Alpargatas S.A. & Vencedoras & $-0,814$ & 0,050 & Perdedoras & Erro \\
\hline
\end{tabular}

(Continua) 
(Conclui)

\begin{tabular}{|c|c|c|c|c|c|}
\hline Empresa & $\begin{array}{c}\text { Grupo } \\
\text { Atual } \\
\end{array}$ & \begin{tabular}{c|}
$\mathrm{Z}$ \\
Discriminante
\end{tabular} & $\begin{array}{c}\text { Ponto de Corte } \\
(\mathrm{Z} \text { ec })\end{array}$ & $\begin{array}{c}\text { Grupo } \\
\text { Previsto }\end{array}$ & Análise \\
\hline Alpargatas S.A. & Vencedoras & $-0,814$ & 0,050 & Perdedoras & Erro \\
\hline Vale S.A & Perdedoras & 0,482 & 0,050 & Vencedoras & Erro \\
\hline Trisul S.A. & Perdedoras & $-0,697$ & 0,050 & Perdedoras & Ok \\
\hline Tereos Internacional S.A. & Perdedoras & 1,122 & 0,050 & Vencedoras & Erro \\
\hline Tempo Participacoes S.A. & Perdedoras & $-0,953$ & 0,050 & Perdedoras & $\mathrm{Ok}$ \\
\hline $\begin{array}{l}\text { Saraiva S.A. Livreiros } \\
\text { Editores }\end{array}$ & Perdedoras & $-0,449$ & 0,050 & Perdedoras & Ok \\
\hline $\begin{array}{l}\text { Rodobens Negocios } \\
\text { Imobiliarios S.A. }\end{array}$ & Perdedoras & $-1,719$ & 0,050 & Perdedoras & Ok \\
\hline Prumo Logística S.A. & Perdedoras & $-10,104$ & 0,050 & Perdedoras & Ok \\
\hline $\begin{array}{l}\text { Profarma Distrib Prod } \\
\text { Farmaceuticos S.A. }\end{array}$ & Perdedoras & $-0,490$ & 0,050 & Perdedoras & Ok \\
\hline Paranapanema S.A. & Perdedoras & $-0,679$ & 0,050 & Perdedoras & Ok \\
\hline $\begin{array}{l}\text { Profarma Distrib Prod } \\
\text { Farmaceuticos S.A. }\end{array}$ & Perdedoras & $-1,157$ & 0,050 & Perdedoras & Ok \\
\hline Positivo Informatica S.A. & Perdedoras & 0,233 & 0,050 & Vencedoras & Erro \\
\hline Natura Cosmeticos S.A. & Perdedoras & $-0,182$ & 0,050 & Perdedoras & Ok \\
\hline Metalfrio Solutions S.A. & Perdedoras & $-0,406$ & 0,050 & Perdedoras & Ok \\
\hline Marisa Lojas S.A. & Perdedoras & $-0,701$ & 0,050 & Perdedoras & Ok \\
\hline Magnesita Refratarios S.A. & Perdedoras & $-0,982$ & 0,050 & Perdedoras & Ok \\
\hline $\begin{array}{l}\text { Lps Brasil - Consultoria De } \\
\text { Imoveis S.A. }\end{array}$ & Perdedoras & $-0,099$ & 0,050 & Perdedoras & Ok \\
\hline Industrias Romi S.A. & Perdedoras & $-0,653$ & 0,050 & Perdedoras & Ok \\
\hline Hypermarcas S.A. & Perdedoras & $-1,331$ & 0,050 & Perdedoras & Ok \\
\hline Grendene S.A. & Perdedoras & $-5,350$ & 0,050 & Perdedoras & Ok \\
\hline Gerdau S.A. & Perdedoras & $-0,112$ & 0,050 & Perdedoras & Ok \\
\hline Gafisa S.A. & Perdedoras & $-3,321$ & 0,050 & Perdedoras & Ok \\
\hline Fibria Celulose S.A. & Perdedoras & 2,789 & 0,050 & Vencedoras & Erro \\
\hline Fertilizantes Heringer S.A. & Perdedoras & 0,756 & 0,050 & Vencedoras & Erro \\
\hline Eternit S.A. & Perdedoras & $-0,440$ & 0,050 & Perdedoras & $\mathrm{Ok}$ \\
\hline Estacio Participacoes S.A. & Perdedoras & $-2,021$ & 0,050 & Perdedoras & Ok \\
\hline $\begin{array}{l}\text { Cyrela Brazil Realty } \\
\text { S.A.Empreend E Part }\end{array}$ & Perdedoras & $-0,718$ & 0,050 & Perdedoras & Ok \\
\hline Csu Cardsystem S.A. & Perdedoras & 0,711 & 0,050 & Vencedoras & Erro \\
\hline $\begin{array}{l}\text { Centrais Elet De Santa } \\
\text { Catarina S.A. }\end{array}$ & Perdedoras & 0,711 & 0,050 & Vencedoras & Erro \\
\hline $\begin{array}{l}\text { Brasil Brokers Participacoes } \\
\text { S.A. }\end{array}$ & Perdedoras & $-0,629$ & 0,050 & Perdedoras & Ok \\
\hline Bematech S.A. & Perdedoras & $-2,176$ & 0,050 & Perdedoras & Ok \\
\hline B2w - Companhia Digital & Perdedoras & $-0,508$ & 0,050 & Perdedoras & Ok \\
\hline $\begin{array}{l}\text { All America Latina Logistica } \\
\text { S.A. }\end{array}$ & Perdedoras & 1,134 & 0,050 & Vencedoras & Erro \\
\hline
\end{tabular}

Fonte: Elaborada pela autora. 
Tabela A8 - Detalhamento da Classificação de empresas - Exercício 2012

\begin{tabular}{|c|c|c|c|c|c|}
\hline Empresa & $\begin{array}{l}\text { Grupo } \\
\text { Atual }\end{array}$ & $\begin{array}{c}\mathrm{Z} \\
\text { Discriminante }\end{array}$ & $\begin{array}{l}\text { Ponto de Corte } \\
(\mathrm{Z} \text { ec })\end{array}$ & $\begin{array}{c}\text { Grupo } \\
\text { Previsto }\end{array}$ & Análise \\
\hline $\begin{array}{l}\text { Valid Soluções E Serv. } \\
\text { Seg. Meios Pag. Ident. S.A. }\end{array}$ & Vencedoras & 1,412 & $-0,031$ & Vencedoras & Ok \\
\hline $\begin{array}{l}\text { Tpi - Triunfo Particip. E } \\
\text { Invest. S.A. }\end{array}$ & Vencedoras & 0,440 & $-0,031$ & Vencedoras & Ok \\
\hline $\begin{array}{l}\text { Suzano Papel E Celulose } \\
\text { S.A. }\end{array}$ & Vencedoras & $-0,309$ & $-0,031$ & Perdedoras & Erro \\
\hline $\begin{array}{l}\text { Cia Saneamento Basico Est } \\
\text { Sao Paulo }\end{array}$ & Vencedoras & 0,086 & $-0,031$ & Vencedoras & Ok \\
\hline Raia Drogasil S.A. & Vencedoras & 3,845 & $-0,031$ & Vencedoras & $\mathrm{Ok}$ \\
\hline Portobello S.A. & Vencedoras & 0,319 & $-0,031$ & Vencedoras & Ok \\
\hline Marcopolo S.A. & Vencedoras & 0,173 & $-0,031$ & Vencedoras & Ok \\
\hline Paranapanema S.A. & Vencedoras & $-1,671$ & $-0,031$ & Perdedoras & Erro \\
\hline Natura Cosmeticos S.A. & Vencedoras & 5,030 & $-0,031$ & Vencedoras & $\mathrm{Ok}$ \\
\hline Iochpe Maxion S.A. & Vencedoras & 1,751 & $-0,031$ & Vencedoras & Ok \\
\hline $\begin{array}{l}\text { M.Dias Branco S.A. Ind } \\
\text { Com De Alimentos }\end{array}$ & Vencedoras & 1,969 & $-0,031$ & Vencedoras & Ok \\
\hline Lojas Renner S.A. & Vencedoras & 2,383 & $-0,031$ & Vencedoras & Ok \\
\hline $\begin{array}{l}\text { Lps Brasil - Consultoria De } \\
\text { Imoveis S.A. }\end{array}$ & Vencedoras & 1,250 & $-0,031$ & Vencedoras & Ok \\
\hline Kroton Educacional S.A. & Vencedoras & 8,379 & $-0,031$ & Vencedoras & Ok \\
\hline Klabin S.A. & Vencedoras & 0,331 & $-0,031$ & Vencedoras & Ok \\
\hline Jhsf Participacoes S.A. & Vencedoras & 0,103 & $-0,031$ & Vencedoras & Ok \\
\hline Hypermarcas S.A. & Vencedoras & 0,582 & $-0,031$ & Vencedoras & Ok \\
\hline $\begin{array}{l}\text { Helbor Empreendimentos } \\
\text { S.A. }\end{array}$ & Vencedoras & 1,749 & $-0,031$ & Vencedoras & Ok \\
\hline Grendene S.A. & Vencedoras & 1,683 & $-0,031$ & Vencedoras & Ok \\
\hline Fertilizantes Heringer S.A. & Vencedoras & $-2,432$ & $-0,031$ & Perdedoras & Erro \\
\hline $\begin{array}{l}\text { Ez Tec Empreend. E } \\
\text { Participacoes S.A. }\end{array}$ & Vencedoras & 0,379 & $-0,031$ & Vencedoras & Ok \\
\hline $\begin{array}{l}\text { Even Construtora E } \\
\text { Incorporadora S.A. }\end{array}$ & Vencedoras & 0,412 & $-0,031$ & Vencedoras & Ok \\
\hline Estacio Participacoes S.A. & Vencedoras & 2,217 & $-0,031$ & Vencedoras & Ok \\
\hline Equatorial Energia S.A. & Vencedoras & 1,354 & $-0,031$ & Vencedoras & Ok \\
\hline Direcional Engenharia S.A. & Vencedoras & 1,000 & $-0,031$ & Vencedoras & Ok \\
\hline Cer S.A. & Vencedoras & 2,963 & $-0,031$ & Vencedoras & Ok \\
\hline B2w - Companhia Digital & Vencedoras & $-0,648$ & $-0,031$ & Perdedoras & Erro \\
\hline Bematech S.A. & Vencedoras & $-0,973$ & $-0,031$ & Perdedoras & Erro \\
\hline Minerva S.A. & Vencedoras & $-1,080$ & $-0,031$ & Perdedoras & Erro \\
\hline Arteris S.A. & Vencedoras & 0,946 & $-0,031$ & Vencedoras & $\mathrm{Ok}$ \\
\hline Marisa Lojas S.A. & Vencedoras & 1,896 & $-0,031$ & Vencedoras & Ok \\
\hline
\end{tabular}

(Continua) 
(Conclui)

\begin{tabular}{|c|c|c|c|c|c|}
\hline Empresa & $\begin{array}{c}\text { Grupo } \\
\text { Atual }\end{array}$ & $\begin{array}{c}\mathrm{Z} \\
\text { Discriminante }\end{array}$ & $\begin{array}{c}\text { Ponto de } \\
\text { Corte }(\mathrm{Z} \text { ec })\end{array}$ & $\begin{array}{c}\text { Grupo } \\
\text { Previsto }\end{array}$ & Análise \\
\hline $\begin{array}{l}\text { Usinas Sid De Minas Gerais } \\
\text { S.A.-Usiminas }\end{array}$ & Perdedoras & $-0,522$ & $-0,031$ & Perdedoras & Ok \\
\hline $\begin{array}{l}\text { Cteep - Cia Transmissão } \\
\text { Energia Elétrica Paulista } \\
\end{array}$ & Perdedoras & $-1,730$ & $-0,031$ & Perdedoras & Ok \\
\hline Trisul S.A. & Perdedoras & $-1,513$ & $-0,031$ & Perdedoras & Ok \\
\hline Tempo Participacoes S.A. & Perdedoras & $-2,123$ & $-0,031$ & Perdedoras & Ok \\
\hline Tecnisa S.A. & Perdedoras & 1,865 & $-0,031$ & Vencedoras & Erro \\
\hline Tractebel Energia S.A. & Perdedoras & $-1,713$ & $-0,031$ & Perdedoras & $\mathrm{Ok}$ \\
\hline Sao Martinho S.A. & Perdedoras & $-0,127$ & $-0,031$ & Perdedoras & $\mathrm{Ok}$ \\
\hline Rossi Residencial S.A. & Perdedoras & $-1,795$ & $-0,031$ & Perdedoras & $\mathrm{Ok}$ \\
\hline $\begin{array}{l}\text { Rodobens Negocios } \\
\text { Imobiliarios S.A. }\end{array}$ & Perdedoras & $-0,162$ & $-0,031$ & Perdedoras & Ok \\
\hline Positivo Informatica S.A. & Perdedoras & $-2,163$ & $-0,031$ & Perdedoras & Ok \\
\hline $\begin{array}{l}\text { Profarma Distrib Prod } \\
\text { Farmaceuticos S.A. }\end{array}$ & Perdedoras & $-2,078$ & $-0,031$ & Perdedoras & Ok \\
\hline Light S.A & Perdedoras & $-0,724$ & $-0,031$ & Perdedoras & Ok \\
\hline Jbs S.A. & Perdedoras & $-1,654$ & $-0,031$ & Perdedoras & Ok \\
\hline Ideaisnet S.A & Perdedoras & $-2,383$ & $-0,031$ & Perdedoras & Ok \\
\hline Gafisa S.A. & Perdedoras & $-0,824$ & $-0,031$ & Perdedoras & Ok \\
\hline Metalfrio Solutions S.A. & Perdedoras & $-1,658$ & $-0,031$ & Perdedoras & Ok \\
\hline Eternit S.A. & Perdedoras & $-1,050$ & $-0,031$ & Perdedoras & Ok \\
\hline $\begin{array}{l}\text { Eletropaulo Metrop. Elet. Sao } \\
\text { Paulo S.A. }\end{array}$ & Perdedoras & $-1,272$ & $-0,031$ & Perdedoras & Ok \\
\hline $\begin{array}{l}\text { Centrais Elet Bras S.A. - } \\
\text { Eletrobras }\end{array}$ & Perdedoras & $-1,059$ & $-0,031$ & Perdedoras & Ok \\
\hline $\begin{array}{l}\text { Diagnosticos Da America } \\
\text { S.A. }\end{array}$ & Perdedoras & $-0,204$ & $-0,031$ & Perdedoras & Ok \\
\hline $\begin{array}{l}\text { Cosan S.A. Industria E } \\
\text { Comercio }\end{array}$ & Perdedoras & $-0,189$ & $-0,031$ & Perdedoras & Ok \\
\hline $\begin{array}{l}\text { Cr2 Empreendimentos } \\
\text { Imobiliarios S.A. }\end{array}$ & Perdedoras & $-1,584$ & $-0,031$ & Perdedoras & Ok \\
\hline $\begin{array}{l}\text { Cia Paranaense De Energia - } \\
\text { Copel }\end{array}$ & Perdedoras & $-0,707$ & $-0,031$ & Perdedoras & Ok \\
\hline Cpfl Energia S.A. & Perdedoras & 0,548 & $-0,031$ & Vencedoras & Erro \\
\hline $\begin{array}{l}\text { Cia Energetica De Minas } \\
\text { Gerais - Cemig }\end{array}$ & Perdedoras & $-0,801$ & $-0,031$ & Perdedoras & Ok \\
\hline $\begin{array}{l}\text { Centrais Elet De Santa } \\
\text { Catarina S.A. }\end{array}$ & Perdedoras & $-1,332$ & $-0,031$ & Perdedoras & Ok \\
\hline $\begin{array}{l}\text { Cesp - Cia Energetica De Sao } \\
\text { Paulo }\end{array}$ & Perdedoras & $-0,206$ & $-0,031$ & Perdedoras & $\mathrm{Ok}$ \\
\hline Csu Cardsystem S.A. & Perdedoras & $-1,951$ & $-0,031$ & Perdedoras & Ok \\
\hline Braskem S.A. & Perdedoras & $-1,060$ & $-0,031$ & Perdedoras & Ok \\
\hline $\begin{array}{l}\text { All America Latina Logistica } \\
\text { S.A. }\end{array}$ & Perdedoras & $-0,054$ & $-0,031$ & Perdedoras & Ok \\
\hline
\end{tabular}

Fonte: Elaborada pela autora. 
Tabela A9 - Detalhamento da Classificação de empresas - Exercício 2013

\begin{tabular}{|c|c|c|c|c|c|}
\hline Empresa & $\begin{array}{l}\text { Grupo } \\
\text { Atual }\end{array}$ & $\begin{array}{c}\mathrm{Z} \\
\text { Discriminante }\end{array}$ & $\begin{array}{c}\text { Ponto de } \\
\text { Corte }(\mathrm{Z} \mathrm{ec})\end{array}$ & $\begin{array}{c}\text { Grupo } \\
\text { Previsto }\end{array}$ & Análise \\
\hline Weg S.A & Vencedoras & 0,245 & 0,026 & Vencedoras & Ok \\
\hline Vanguarda Agro S.A. & Vencedoras & $-0,334$ & 0,026 & Perdedoras & Erro \\
\hline Tecnisa S.A. & Vencedoras & $-1,554$ & 0,026 & Perdedoras & Erro \\
\hline Sao Martinho S.A. & Vencedoras & $-0,915$ & 0,026 & Perdedoras & Erro \\
\hline $\begin{array}{l}\text { Suzano Papel E Celulose } \\
\text { S.A. }\end{array}$ & Vencedoras & $-1,806$ & 0,026 & Perdedoras & Erro \\
\hline Slc Agricola S.A. & Vencedoras & 0,090 & 0,026 & Vencedoras & Ok \\
\hline $\begin{array}{l}\text { Saraiva S.A. Livreiros } \\
\text { Editores }\end{array}$ & Vencedoras & 0,189 & 0,026 & Vencedoras & Ok \\
\hline $\begin{array}{l}\text { Cia Brasileira De } \\
\text { Distribuicao }\end{array}$ & Vencedoras & 0,498 & 0,026 & Vencedoras & Ok \\
\hline $\begin{array}{l}\text { Profarma Distrib Prod } \\
\text { Farmaceuticos S.A. }\end{array}$ & Vencedoras & 0,109 & 0,026 & Vencedoras & Ok \\
\hline Portobello S.A. & Vencedoras & 1,715 & 0,026 & Vencedoras & Ok \\
\hline Paranapanema S.A. & Vencedoras & $-0,579$ & 0,026 & Perdedoras & Erro \\
\hline Minerva S.A. & Vencedoras & $-4,002$ & 0,026 & Perdedoras & Erro \\
\hline Metalfrio Solutions S.A. & Vencedoras & $-0,393$ & 0,026 & Perdedoras & Erro \\
\hline $\begin{array}{l}\text { M.Dias Branco S.A. Ind } \\
\text { Com De Alimentos }\end{array}$ & Vencedoras & 0,479 & 0,026 & Vencedoras & Ok \\
\hline $\begin{array}{l}\text { Log-In Logistica } \\
\text { Intermodal S.A. }\end{array}$ & Vencedoras & $-1,630$ & 0,026 & Perdedoras & Erro \\
\hline Jbs S.A & Vencedoras & $-1,112$ & 0,026 & Perdedoras & Erro \\
\hline Hypermarcas S.A. & Vencedoras & $-0,828$ & 0,026 & Perdedoras & Erro \\
\hline Grendene S.A & Vencedoras & 1,787 & 0,026 & Vencedoras & $\mathrm{Ok}$ \\
\hline Fras-Le S.A. & Vencedoras & $-0,571$ & 0,026 & Perdedoras & Erro \\
\hline Fibria Celulose S.A & Vencedoras & $-1,239$ & 0,026 & Perdedoras & Erro \\
\hline $\begin{array}{l}\text { Ez Tec Empreend. E } \\
\text { Participacoes S.A. }\end{array}$ & Vencedoras & $-1,295$ & 0,026 & Perdedoras & Erro \\
\hline Eternit S.A & Vencedoras & 0,882 & 0,026 & Vencedoras & $\mathrm{Ok}$ \\
\hline Estacio Participacoes S.A. & Vencedoras & $-0,148$ & 0,026 & Perdedoras & Erro \\
\hline Equatorial Energia S.A. & Vencedoras & $-2,964$ & 0,026 & Perdedoras & Erro \\
\hline $\begin{array}{l}\text { Cosan S.A. Industria E } \\
\text { Comercio }\end{array}$ & Vencedoras & 1,003 & 0,026 & Vencedoras & $\mathrm{Ok}$ \\
\hline $\begin{array}{l}\text { Centrais Elet Bras S.A. - } \\
\text { Eletrobras }\end{array}$ & Vencedoras & $-0,156$ & 0,026 & Perdedoras & Erro \\
\hline Brf S.A. & Vencedoras & 0,181 & 0,026 & Vencedoras & $\mathrm{Ok}$ \\
\hline Braskem S.A. & Vencedoras & $-0,892$ & 0,026 & Perdedoras & Erro \\
\hline Bematech S.A & Vencedoras & 0,625 & 0,026 & Vencedoras & $\mathrm{Ok}$ \\
\hline Arteris S.A. & Vencedoras & $-0,409$ & 0,026 & Perdedoras & Erro \\
\hline Alpargatas S.A. & Vencedoras & 0,725 & 0,026 & Vencedoras & Ok \\
\hline
\end{tabular}

(Continua) 
(Conclui)

\begin{tabular}{|c|c|c|c|c|c|}
\hline Empresa & $\begin{array}{l}\text { Grupo } \\
\text { Atual }\end{array}$ & $\begin{array}{c}\mathrm{Z} \\
\text { Discriminante }\end{array}$ & $\begin{array}{c}\text { Ponto de } \\
\text { Corte }(\mathrm{Z} \text { ec })\end{array}$ & $\begin{array}{c}\text { Grupo } \\
\text { Previsto }\end{array}$ & Análise \\
\hline $\begin{array}{l}\text { Valid Soluções E Serv. Seg. } \\
\text { Meios Pag. Ident. S.A. }\end{array}$ & Perdedoras & $-1,114$ & 0,026 & Perdedoras & Ok \\
\hline Trisul S.A. & Perdedoras & 1,585 & 0,026 & Vencedoras & Erro \\
\hline Tegma Gestao Logistica S.A. & Perdedoras & $-0,482$ & 0,026 & Perdedoras & $\mathrm{Ok}$ \\
\hline Santos Brasil Participacoes S.A. & Perdedoras & 0,342 & 0,026 & Vencedoras & Erro \\
\hline Rossi Residencial S.A. & Perdedoras & 0,169 & 0,026 & Vencedoras & Erro \\
\hline Positivo Informatica S.A. & Perdedoras & 0,307 & 0,026 & Vencedoras & Erro \\
\hline $\begin{array}{l}\text { Profarma Distrib Prod } \\
\text { Farmaceuticos S.A. }\end{array}$ & Perdedoras & $-1,537$ & 0,026 & Perdedoras & Ok \\
\hline Natura Cosmeticos S.A & Perdedoras & 2,399 & 0,026 & Vencedoras & Erro \\
\hline Marisa Lojas S.A. & Perdedoras & $-0,159$ & 0,026 & Perdedoras & Ok \\
\hline Marfrig Global Foods S.A. & Perdedoras & $-2,585$ & 0,026 & Perdedoras & $\mathrm{Ok}$ \\
\hline $\begin{array}{l}\text { Lps Brasil - Consultoria De } \\
\text { Imoveis S.A. }\end{array}$ & Perdedoras & 0,111 & 0,026 & Vencedoras & Erro \\
\hline Lojas Renner S.A. & Perdedoras & 1,166 & 0,026 & Vencedoras & Erro \\
\hline Kroton Educacional S.A. & Perdedoras & $-1,282$ & 0,026 & Perdedoras & $\mathrm{Ok}$ \\
\hline Jhsf Participacoes S.A. & Perdedoras & 0,251 & 0,026 & Vencedoras & Erro \\
\hline Industrias Romi S.A. & Perdedoras & $-0,402$ & 0,026 & Perdedoras & Ok \\
\hline Ideiasnet S.A & Perdedoras & 0,854 & 0,026 & Vencedoras & Erro \\
\hline Gafisa S.A & Perdedoras & 1,715 & 0,026 & Vencedoras & Erro \\
\hline Fleury S.A. & Perdedoras & $-1,473$ & 0,026 & Perdedoras & $\mathrm{Ok}$ \\
\hline Fertilizantes Heringer S.A. & Perdedoras & 0,816 & 0,026 & Vencedoras & Erro \\
\hline $\begin{array}{l}\text { Eletropaulo Metrop. Elet. Sao } \\
\text { Paulo S.A. }\end{array}$ & Perdedoras & $-0,190$ & 0,026 & Perdedoras & Ok \\
\hline Edp - Energias Do Brasil S.A. & Perdedoras & 0,165 & 0,026 & Vencedoras & Erro \\
\hline Raia Drogasil S.A. & Perdedoras & 0,514 & 0,026 & Vencedoras & Erro \\
\hline Direcional Engenharia S.A. & Perdedoras & $-0,453$ & 0,026 & Perdedoras & $\mathrm{Ok}$ \\
\hline Csu Cardsystem S.A. & Perdedoras & $-0,395$ & 0,026 & Perdedoras & Ok \\
\hline $\begin{array}{l}\text { Cr2 Empreendimentos } \\
\text { Imobiliarios S.A. }\end{array}$ & Perdedoras & 1,409 & 0,026 & Vencedoras & Erro \\
\hline Cia Hering & Perdedoras & 2,105 & 0,026 & Vencedoras & Erro \\
\hline $\begin{array}{l}\text { Cteep - Cia Transmissão Energia } \\
\text { Elétrica Paulista }\end{array}$ & Perdedoras & 1,149 & 0,026 & Vencedoras & Erro \\
\hline $\begin{array}{l}\text { Centrais Elet De Santa Catarina } \\
\text { S.A. }\end{array}$ & Perdedoras & $-0,303$ & 0,026 & Perdedoras & Ok \\
\hline Brasil Brokers Participacoes S.A. & Perdedoras & 1,346 & 0,026 & Vencedoras & Erro \\
\hline $\begin{array}{l}\text { Bhg Sa - Brazil Hospitality } \\
\text { Group }\end{array}$ & Perdedoras & $-0,776$ & 0,026 & Perdedoras & Ok \\
\hline $\begin{array}{l}\text { Valid Soluções E Serv. Seg. } \\
\text { Meios Pag. Ident. S.A. }\end{array}$ & Perdedoras & $-1,114$ & 0,026 & Perdedoras & Ok \\
\hline
\end{tabular}

Fonte: Elaborada pela autora. 
Tabela A10 - Detalhamento da Classificação de empresas - Exercício 2014

\begin{tabular}{|c|c|c|c|c|c|}
\hline Empresa & $\begin{array}{l}\text { Grupo } \\
\text { Atual }\end{array}$ & $\begin{array}{c}\mathrm{Z} \\
\text { Discriminante } \\
\end{array}$ & $\begin{array}{c}\text { Ponto de } \\
\text { Corte }(\mathrm{Z} \text { ec })\end{array}$ & $\begin{array}{c}\text { Grupo } \\
\text { Previsto }\end{array}$ & Análise \\
\hline Weg S.A & Vencedoras & 2,086 & $-0,042$ & Vencedoras & Ok \\
\hline $\begin{array}{l}\text { Valid Soluções E Serv. Seg. } \\
\text { Meios Pag. Ident. S.A. }\end{array}$ & Vencedoras & 1,386 & $-0,042$ & Vencedoras & Ok \\
\hline $\begin{array}{l}\text { Tpi - Triunfo Particip. E } \\
\text { Invest. S.A. }\end{array}$ & Vencedoras & 2,342 & $-0,042$ & Vencedoras & Ok \\
\hline Tempo Participacoes S.A. & Vencedoras & 2,031 & $-0,042$ & Vencedoras & Ok \\
\hline Suzano Papel E Celulose S.A. & Vencedoras & 0,122 & $-0,042$ & Vencedoras & Ok \\
\hline Prumo Logística S.A. & Vencedoras & 3,553 & $-0,042$ & Vencedoras & Ok \\
\hline Portobello S.A. & Vencedoras & 0,990 & $-0,042$ & Vencedoras & $\mathrm{Ok}$ \\
\hline Minerva S.A. & Vencedoras & 1,714 & $-0,042$ & Vencedoras & Ok \\
\hline Marfrig Global Foods S.A. & Vencedoras & $-0,058$ & $-0,042$ & Perdedoras & Erro \\
\hline Lojas Renner S.A. & Vencedoras & 2,458 & $-0,042$ & Vencedoras & $\mathrm{Ok}$ \\
\hline Light S.A & Vencedoras & $-0,124$ & $-0,042$ & Perdedoras & Erro \\
\hline Kroton Educacional S.A. & Vencedoras & 2,550 & $-0,042$ & Vencedoras & Ok \\
\hline Klabin S.A. & Vencedoras & 0,083 & $-0,042$ & Vencedoras & Ok \\
\hline Jbs S.A & Vencedoras & 0,289 & $-0,042$ & Vencedoras & $\mathrm{Ok}$ \\
\hline Ideiasnet S.A & Vencedoras & 0,053 & $-0,042$ & Vencedoras & Ok \\
\hline Fibria Celulose S.A. & Vencedoras & $-0,605$ & $-0,042$ & Perdedoras & Erro \\
\hline Fertilizantes Heringer S.A. & Vencedoras & $-0,809$ & $-0,042$ & Perdedoras & Erro \\
\hline Estacio Participacoes S.A. & Vencedoras & 1,671 & $-0,042$ & Vencedoras & $\mathrm{Ok}$ \\
\hline Equatorial Energia S.A. & Vencedoras & 1,079 & $-0,042$ & Vencedoras & Ok \\
\hline $\begin{array}{l}\text { Eletropaulo Metrop. Elet. Sao } \\
\text { Paulo S.A. }\end{array}$ & Vencedoras & $-0,590$ & $-0,042$ & Perdedoras & Erro \\
\hline Raia Drogasil S.A. & Vencedoras & 1,255 & $-0,042$ & Vencedoras & Ok \\
\hline Cpfl Energia S.A. & Vencedoras & 0,714 & $-0,042$ & Vencedoras & Ok \\
\hline $\begin{array}{l}\text { Cia Paranaense De Energia - } \\
\text { Copel }\end{array}$ & Vencedoras & 0,411 & $-0,042$ & Vencedoras & Ok \\
\hline $\begin{array}{l}\text { Cia Energetica De Minas } \\
\text { Gerais - Cemig }\end{array}$ & Vencedoras & 0,523 & $-0,042$ & Vencedoras & Ok \\
\hline $\begin{array}{l}\text { Cteep - Cia Transmissão } \\
\text { Energia Elétrica Paulista }\end{array}$ & Vencedoras & $-0,267$ & $-0,042$ & Perdedoras & Erro \\
\hline $\begin{array}{l}\text { Centrais Elet De Santa } \\
\text { Catarina S.A. }\end{array}$ & Vencedoras & $-0,461$ & $-0,042$ & Perdedoras & Erro \\
\hline $\begin{array}{l}\text { Centrais Elet Bras S.A. - } \\
\text { Eletrobras }\end{array}$ & Vencedoras & $-0,568$ & $-0,042$ & Perdedoras & Erro \\
\hline Brf S.A. & Vencedoras & 0,913 & $-0,042$ & Vencedoras & $\mathrm{Ok}$ \\
\hline $\begin{array}{l}\text { Bhg Sa - Brazil Hospitality } \\
\text { Group }\end{array}$ & Vencedoras & $-0,099$ & $-0,042$ & Perdedoras & Erro \\
\hline Bematech S.A. & Vencedoras & $-0,276$ & $-0,042$ & Perdedoras & Erro \\
\hline
\end{tabular}


(Conclui)

\begin{tabular}{|c|c|c|c|c|c|}
\hline Empresa & $\begin{array}{l}\text { Grupo } \\
\text { Atual } \\
\end{array}$ & $\begin{array}{c}\mathrm{Z} \\
\text { Discriminante } \\
\end{array}$ & $\begin{array}{c}\text { Ponto de } \\
\text { Corte }(\mathrm{Z} \mathrm{ec}) \\
\end{array}$ & $\begin{array}{c}\text { Grupo } \\
\text { Previsto } \\
\end{array}$ & Análise \\
\hline B2w - Companhia Digital & Vencedoras & 0,645 & $-0,042$ & Vencedoras & Ok \\
\hline Vanguarda Agro S.A. & Perdedoras & $-0,654$ & $-0,042$ & Perdedoras & $\mathrm{Ok}$ \\
\hline Vale S.A & Perdedoras & $-1,363$ & $-0,042$ & Perdedoras & Ok \\
\hline Trisul S.A. & Perdedoras & $-2,047$ & $-0,042$ & Perdedoras & Ok \\
\hline $\begin{array}{l}\text { Saraiva S.A. Livreiros } \\
\text { Editores }\end{array}$ & Perdedoras & $-1,047$ & $-0,042$ & Perdedoras & Ok \\
\hline $\begin{array}{l}\text { Santos Brasil Participacoes } \\
\text { S.A. }\end{array}$ & Perdedoras & $-1,455$ & $-0,042$ & Perdedoras & Ok \\
\hline $\begin{array}{l}\text { Cia Saneamento Basico Est } \\
\text { Sao Paulo }\end{array}$ & Perdedoras & $-0,934$ & $-0,042$ & Perdedoras & Ok \\
\hline Rossi Residencial S.A. & Perdedoras & $-2,087$ & $-0,042$ & Perdedoras & Ok \\
\hline $\begin{array}{l}\text { Rodobens Negocios } \\
\text { Imobiliarios S.A. }\end{array}$ & Perdedoras & $-1,449$ & $-0,042$ & Perdedoras & Ok \\
\hline $\begin{array}{l}\text { Randon S.A. Implementos } \\
\text { E Participacoes }\end{array}$ & Perdedoras & $-1,327$ & $-0,042$ & Perdedoras & Ok \\
\hline $\begin{array}{l}\text { Profarma Distrib Prod } \\
\text { Farmaceuticos S.A. }\end{array}$ & Perdedoras & $-1,147$ & $-0,042$ & Perdedoras & Ok \\
\hline Positivo Informatica S.A. & Perdedoras & $-1,562$ & $-0,042$ & Perdedoras & Ok \\
\hline Paranapanema S.A. & Perdedoras & $-1,487$ & $-0,042$ & Perdedoras & Ok \\
\hline Marcopolo S.A. & Perdedoras & $-0,511$ & $-0,042$ & Perdedoras & Ok \\
\hline Magnesita Refratarios S.A. & Perdedoras & $-1,089$ & $-0,042$ & Perdedoras & Ok \\
\hline $\begin{array}{l}\text { Lps Brasil - Consultoria De } \\
\text { Imoveis S.A. }\end{array}$ & Perdedoras & $-1,852$ & $-0,042$ & Perdedoras & Ok \\
\hline Iochpe Maxion S.A. & Perdedoras & $-0,922$ & $-0,042$ & Perdedoras & Ok \\
\hline Industrias Romi S.A. & Perdedoras & $-1,352$ & $-0,042$ & Perdedoras & Ok \\
\hline Grendene S.A. & Perdedoras & $-0,139$ & $-0,042$ & Perdedoras & $\mathrm{Ok}$ \\
\hline Gerdau S.A. & Perdedoras & $-0,939$ & $-0,042$ & Perdedoras & $\mathrm{Ok}$ \\
\hline Fras-Le S.A. & Perdedoras & $-0,485$ & $-0,042$ & Perdedoras & Ok \\
\hline $\begin{array}{l}\text { Ez Tec Empreend. E } \\
\text { Participacoes S.A. }\end{array}$ & Perdedoras & $-1,118$ & $-0,042$ & Perdedoras & $\mathrm{Ok}$ \\
\hline $\begin{array}{l}\text { Even Construtora E } \\
\text { Incorporadora S.A. }\end{array}$ & Perdedoras & $-1,418$ & $-0,042$ & Perdedoras & Ok \\
\hline $\begin{array}{l}\text { Eucatex S.A. Industria E } \\
\text { Comercio }\end{array}$ & Perdedoras & $-1,309$ & $-0,042$ & Perdedoras & Ok \\
\hline Direcional Engenharia S.A. & Perdedoras & $-0,823$ & $-0,042$ & Perdedoras & Ok \\
\hline $\begin{array}{l}\text { Cyrela Brazil Realty } \\
\text { S.A.Empreend E Part }\end{array}$ & Perdedoras & $-0,738$ & $-0,042$ & Perdedoras & Ok \\
\hline $\begin{array}{l}\text { Cr2 Empreendimentos } \\
\text { Imobiliarios S.A. }\end{array}$ & Perdedoras & $-3,669$ & $-0,042$ & Perdedoras & Ok \\
\hline $\begin{array}{l}\text { Cosan S.A. Industria E } \\
\text { Comercio }\end{array}$ & Perdedoras & $-0,862$ & $-0,042$ & Perdedoras & Ok \\
\hline $\begin{array}{l}\text { Cia Providencia Industria E } \\
\text { Comercio }\end{array}$ & Perdedoras & $-0,650$ & $-0,042$ & Perdedoras & Ok \\
\hline Cia Hering & Perdedoras & 0,498 & $-0,042$ & Vencedoras & Erro \\
\hline $\begin{array}{l}\text { Brasil Brokers } \\
\text { Participacoes S.A. }\end{array}$ & Perdedoras & $-1,640$ & $-0,042$ & Perdedoras & $\mathrm{Ok}$ \\
\hline
\end{tabular}

Fonte: Elaborada pela autora. 